\title{
Late-Stage Educational Inequality: Can Selection on Noncognitive Skills Explain Waning Social Background Effects?
}

\section{Christian Michael Smitha ${ }^{a}$ Eric Grodsky ${ }^{a}$, John Robert Warren}

${ }^{a}$ University of Wisconsin-Madison, 1180 Observatory Drive, Madison, WI 53706, USA

${ }^{b}$ University of Minnesota, $26719^{\text {th }}$ Avenue South, Minneapolis, MN 55455, USA

Corresponding author: Christian Michael Smith

E-mail addresses: csmith59@wisc.edu (C.M. Smith), egrodsky@ssc.wisc.edu (E. Grodsky), warre046@umn.edu (J.R. Warren)

The research reported here was supported by the Institute of Education Sciences, U.S.

Department of Education, through Award \#R305B150003 to the University of Wisconsin-

Madison. The opinions expressed are those of the authors and do not represent views of the U.S.

Department of Education. 


\section{Introduction}

Social scientists have identified education as a crucial component of the stratification process that links social origins to adult resources including income, occupational standing, and health (Ashenfelter \& Rouse, 1998; Blau \& Duncan, 1967; Cutler \& Lleras-Muney, 2008). Education both enables social reproduction for those more advantaged and paves the way to social mobility, helping many people transcend disadvantages stemming from ascribed characteristics. For example, among those with a terminal bachelor's degree, parental income does not predict achieved income (Hout, 1988; Torche, 2011).

Given the importance of education in stratification processes, social scientists have taken special interest in how education is allocated across groups. As American income inequality increased over the second half of the 20th century, the relationship between parent income and the academic achievement of youth became more pronounced (Reardon, 2011). Concurrently, attainment gaps based on parental income grew at three critical stages of education: high school completion, college attendance, and college completion (Bailey \& Dynarski, 2011).

Intergenerational educational persistence did not change as appreciably over these decades as the association between educational attainment and parental income (Hout \& Janus, 2011), but the U.S. remains one of the high-income countries with the most intergenerational educational persistence (Hertz et al., 2007).

The process of educational attainment unfolds in successive stages over the life-course. Some educational transitions may be more closely tied to social reproduction and mobility than others. Identifying transitions that are especially challenging for less advantaged students is an important step toward targeting interventions at particularly unequal stages. Theoretical claims about the importance of different transitions for social stratification vary. Gamoran (2001) 
divides theoretical accounts of education's role in social stratification into those based on economic factors and those based on cultural and social factors. Economic factors that influence educational attainment include access to amenities that boost achievement, such as quiet study spaces, tutors, books, and supplies, as well as resources necessary to pay tuition, fees and other costs of attendance at the postsecondary level. Cultural and social factors include tastes and habits that facilitate educational success and social networks that serve as information channels about navigating school. On the one hand, late stages might be less egalitarian because early stages enjoy public provision, which removes the barrier of affordability for schooling per se. On the other hand, early stages might be more egalitarian because parents arguably have a greater influence on their children's cultural dispositions and social networks when the children are young (Müller \& Karle, 1993).

Empirical research extending back to Mare (1980) has suggested that earlier transitions are more closely tied to social stratification than later transitions. Mare found that socioeconomic gradients in completion were more pronounced in the early grades than later grades, to the point of appearing irrelevant for postsecondary outcomes conditional on high school attainment. This has come to be called the "waning coefficients" finding. The waning coefficients finding was striking in part because of its policy implications: if disparities are greater early on, then public policy should target socioeconomic inequalities in early transitions and put less emphasis on later inequalities. After all, interventions designed to close disparities in college attendance, for example, are fruitless if there is no conditional disparity to begin with.

Mare used an innovative analytical strategy to assess how much SES effects differed across levels of schooling. Instead of conceiving of educational attainment as a singular outcome (highest grade completed), he approached it as a series of binary decisions to continue schooling. 
For each major educational transition — starting with the attainment of 8th grade and ending with entry into graduate school—he used a logistic regression model to estimate the odds of making the transition conditional on having successfully made all prior transitions and observed that the estimated effect of SES was smaller for successively higher transitions. By conditioning out marginal changes in the distribution of education, Mare's approach became important in stratification scholarship because it allowed researchers to compare the extent of socioeconomic advantage across nations (Shavit \& Blossfeld, 1993) and across cohorts (Raftery \& Hout, 1993.) An important limitation of Mare's method is that the true effects of SES may not decrease but only appear to do so because of selective attrition (Cameron \& Heckman, 1998; Mare, 1980). For example, if conscientiousness has a positive impact on one's propensity to make educational transitions, those low-SES persons who graduate high school will be more conscientious than those who do not, and therefore will be a subset of the low-SES population disproportionately likely to enter college. Meanwhile, high-SES students, who can rely on material and sociocultural advantages, are likely to graduate high school even if they lack conscientiousness. Selective attrition may then decrease the apparent association between SES and conscientiousness, translating to a downwardly biased estimate of the effect of SES on college entry. Selective attrition occurs whether or not SES moderates the effect of skills on school continuation (Elwert \& Winship, 2014), but for skills that benefit low-SES individuals more than high-SES individuals (Lundberg, 2013), selective attrition is driven both by uniform screening processes that disproportionately reduce continuation among low-SES people and by socioeconomic differences in the relationship between school continuation and these skills.

Selective attrition has implications not only for intergenerational educational mobility, but also intergenerational mobility more broadly defined. Research in the last three decades has 
asked whether a bachelor's degree makes one's social background irrelevant for achieved occupational status, personal income, and total family income. Estimates from a variety of data sources indicate that social background is not significantly associated with occupational and earnings outcomes among those with a terminal bachelor's degree (Hout, 1988; Torche, 2011). However, if the apparent egalitarianism in graduate school entry (Mare, 1980) is due to selective attrition at the transition to college attainment, then the equal occupational and earnings outcomes of low-SES and high-SES bachelor's degree holders is likely also due to selective attrition. In this case, the bachelor's degree does not actually level the playing field, but rather, low-SES college graduates compensate for their disadvantaged background with exceptional cognitive or noncognitive skills.

This paper explores the extent to which selective attrition based on noncognitive skills contributes to observed declines in the association between social origins and educational continuation across levels of educational attainment. While previous work has estimated the extent of selective attrition bias due to academic and cognitive characteristics of students (Lucas, 1996; Mare, 1980) and general unobserved heterogeneity (Buis, 2011; Cameron \& Heckman, 1998; Holm \& Jæger, 2011; Tam, 2011), noncognitive skills are an empirically unexplored source of additional bias.

\section{Noncognitive Skills and Educational Success}

Noncognitive skills include but are not limited to locus of control, self-esteem, conscientiousness, openness to new experiences, extraversion, agreeableness, emotional stability, grit, and self-discipline. While noncognitive skills in fact involve cognition, they are distinct from cognitive ability, which reflects the ability to solve abstract problems (Borghans, 
Duckworth, Heckman, \& ter Weel, 2008). Farkas (2003, pg. 541) argues that an "emerging interdisciplinary paradigm" suggests that noncognitive skills merge with cognitive skills in driving stratification processes. Noncognitive skills predict not only academic achievement and educational attainment (Heckman \& Kautz, 2012), but also labor market outcomes (Lee \& Ohtake, 2012; Wang, Kick, Fraser, \& Burns, 1999) and health-related behaviors (Hampson, Goldberg, Vogt, \& Dubanoski, 2007; Reed, Pritschet, \& Cutton, 2012). For some outcomes, noncognitive skills appear to be more influential than cognitive ability (Heckman \& Kautz, 2012). Since the present study can include only the noncognitive skills of locus of control, selfesteem, and conscientiousness, we focus the following review on these three skills.

\subsection{Locus of control and educational success}

Individuals who interpret events as the result of luck, chance, or fate are said to have an external locus of control, while those who interpret events as the result of their own actions or characteristics are said to have an internal locus of control (Rotter, 1966). Students with an external locus of control may have worse educational outcomes if, due to their view that actions are unrelated to outcomes, they are not motivated to try harder after initially performing poorly (Coleman et al., 1966). Locus of control may also influence educational attainment by affecting students' cost-benefit analyses of continuing their education: students with an internal locus of control estimate higher returns to additional education than those with an external locus of control, who see their labor market outcomes as largely outside their control (Coleman \& DeLeire, 2003).

Among the most significant work on the relationship between locus of control and educational success is Coleman et al.'s Equality of Educational Opportunity study (1966). 
Coleman and his colleagues found that locus of control was more strongly associated with academic achievement than any social background characteristic, and that an internal locus of control was particularly beneficial for low-SES and racial minority students. Using longitudinal data with locus of control measured before ultimate educational attainment, more recent studies have confirmed that an internal locus of control is associated with educational attainment (Coleman \& DeLeire, 2003; Flouri, 2006; Wang et al., 1999). However, scholars since Coleman have also considered that locus of control may be a realistic perception of the degree to which structural constraints limit one's options, rather than simply a disposition that one ought to acquire regardless of context (Bar-Tal \& Bar-Zohar, 1977). For example, undocumented youth experience real, external barriers that compress their opportunities in life, including educational opportunities. Undocumented youth with an external locus of control may simply be aware of the barriers they face, while those with an internal locus of control may simply be misguided. Any interpretation of the association between locus of control and educational attainment should consider that this association may come from life circumstances that the researcher does not observe and over which the student has no control.

\section{2. $\quad$ Self-esteem and educational success}

An individual's self-esteem is his summative evaluation of his own worth (Rosenberg, 1965). Rosenberg's self-esteem scale is based on responses to items such as "On the whole, I am satisfied with myself" and "I am able to do things as well as most other people." Global selfesteem is distinct from self-concept in a specific domain, for example academic self-concept (Marsh \& O’Mara, 2008; Rosenberg, Schooler, Schoenbach, \& Rosenberg, 1995). Still, academic self-concept influences individuals' global self-esteem, and vice versa, especially for 
those who highly value academics (Rosenberg et al., 1995). Therefore, any effect of self-esteem on educational success is likely due to what self-esteem says about academic self-concept: those with low self-esteem are more likely to have a low academic self-concept, and those with a low academic self-concept are likely to shy away from academic challenges because they judge the potential difficulties as more daunting than they really are.

Coleman and his colleagues (1966) thought the strong association between contemporaneous measures of academic self-concept and academic achievement reflected the effects of the latter on the former, but more recent work has shown that, net of prior achievement, academic self-concept is positively associated with later academic achievement and educational attainment (Marsh \& O’Hara, 2008; Rosenberg et al., 1995). While global selfesteem is also positively associated with later educational success, this association is far weaker than the association with academic self-concept (Marsh \& O’Hara, 2008; Rosenberg et al., 1995). Thus, self-esteem probably has some bearing on academic achievement and educational attainment, but pales in comparison to both academic self-concept and locus of control.

\subsection{Conscientiousness and educational success}

Conscientiousness is the tendency to be organized, responsible, and hardworking. Conscientious people are probably better equipped to succeed academically even net of cognitive ability, since they will work to accomplish the academic tasks in front of them and will navigate the hurdles on the path to attainment. For example, students cannot get satisfactory grades solely by having strong cognitive skills; they must also pay attention in class, come prepared with the requisite books or materials, and, especially at higher levels of education, do work at home. In everyday discourse, parents and teachers lament when students do not "apply themselves," i.e., are not 
conscientious. Research confirms that conscientiousness promotes academic achievement and educational attainment in the U.S. (Hampson et al., 2007; Kaiser \& Diewald, 2014; Trapmann, Hell, Hirn, \& Schuler, 2007).

Conscientiousness is one of the "Big Five" personality traits (Almlund et al., 2011). Of these personality traits, conscientiousness has received the most attention in education research because typically it is the strongest predictor of educational outcomes (Lundberg, 2013). On average, conscientiousness increases with age (Soto, John, Gosling, \& Potter, 2011) and has higher test-retest reliability for older people (Roberts \& DelVecchio, 2000). Conscientiousness is moderately rank-stable even between elementary school and midlife, with a rank-order stability coefficient of 0.25 (Hampson \& Goldberg, 2006). As we will elaborate in later sections of this article, we lack direct measures of conscientiousness in adolescence. As proxies for adolescent conscientiousness, we rely on behavioral indicators in high school as well as a direct measure of conscientiousness for a subsample at midlife.

\section{Hypotheses}

In what follows, we assess how much selective attrition by levels of noncognitive skills (together with selective attrition by cognitive skills) can account for the pattern of waning SES effects. In particular, we test the following hypotheses for a cohort of Americans:

(1) Before conditioning on cognitive and noncognitive skills, the estimated effect of socioeconomic variables wanes across transitions.

(2) Conditioning on cognitive and noncognitive skills adjusts for a substantial share of selection attrition bias, yielding estimated SES effects that do not attenuate across transitions. 
Hypothesis (1) follows directly from the fact that the waning coefficients pattern has arisen in multiple prior studies with nonexhaustive covariates (Mare, 1980; Shavit \& Blossfeld, 1993). Whether it is a statistical artifact or not, logistic response models have often displayed a pattern of waning coefficients.

Hypothesis (2) says that the waning coefficients finding is a statistical artifact. The logic is that bias arises since the subset of low-SES individuals at risk of, say, entering college, is a particularly cognitively and noncognitively skilled subset of the low-SES population, and highSES individuals at risk of entering college probably constitute a less steeply selected subset based on such skills, since they have socioeconomic advantages to carry them forward in lieu of skills. When this is the case, parameter estimates are based on a comparison between exceptional low-SES individuals and fairly typical high-SES individuals. Hence, the effect of SES on college entry may appear small relative to its effect on high school attainment simply because the lowSES students who graduate high school are those who have the academic chops to get into college, the internal locus of control to change their initially unfavorable life circumstances, the high self-esteem to deem themselves capable of completing a postsecondary degree, or the effort to acquire college information not available to them at home. We are especially interested in noncognitive skills' contribution to selective attrition bias above and beyond bias due to cognitive skills.

\section{Data and Methods}

\subsection{Data source}

We use data from High School and Beyond, a nationally representative, longitudinal study of a stratified random sample of American high school students. We specifically use the base year 
(1980) and follow-up (1982, 1984, 1986, 1992, 2014) surveys of the 1980 sophomore cohort. The base-year study surveyed 30,030 high school sophomores. The first follow-up solicited responses from all 30,030 persons in the achieved base-year sample. Additionally, a subsample of about 15,000 individuals was selected for a transcript survey the same year (1982). These 15,000 individuals were solicited to participate in the third follow-up (1984), and 98\% responded for an achieved sample of 14,830 cases. About 12,000 of these individuals were resurveyed in 1986 and 1992, and about 9,000 of them were resurveyed in 2014, with 3,710 taking a long form questionnaire that, among other things, included items for measuring conscientiousness. In this paper, we draw most heavily on the 1980 and 1992 surveys. We restrict our main analytic sample to those who responded to both the 1980 and 1992 surveys and who have nonmissing values on their educational attainment and entry. Our final analytic sample size is 10,510.

\subsection{Model specification}

Following Mare (1980), we consider a series of five school transitions: high school attainment (transition 0), baccalaureate college entry (transition 1), baccalaureate college attainment (transition 2), graduate school entry (transition 3), and graduate school attainment (transition 4). For each transition $j$ in [0,4], our Logistic Response Model (LRM) is of the form

$$
\log \left(\frac{p_{i j}}{1-p_{i j}}\right)=\beta_{j}+\sum_{k=1}^{K} \beta_{j k} X_{i k}+\varepsilon_{i j}
$$

where $p_{i j}$ is the probability that person $i$ will make transition $j$ given that she has made transition $j-1^{1}, X_{i k}$ is the value of the $k$ th explanatory variable for individual $i, \beta_{j}$ is a transition-specific intercept, $\beta_{j k}$ is a transition-specific coefficient corresponding to explanatory variable $k$, and $\varepsilon_{i j}$ is

\footnotetext{
${ }^{1}$ In practice, therefore, we delete persons who did not make transition $j-1$ when estimating the model for transition $j$.
} 
a person-specific and transition-specific error term. The outcome variables, corresponding to transitions $j$ in $[0,4]$ respectively, are summarized in Table 1. Each is based on self-reports from the 1982-1992 follow-up questionnaires. Table 1 also summarizes the explanatory variables, all of which are measured in 1980 and determined by self-report unless otherwise specified. Table A.1 in the Appendix gives descriptive statistics on these measures for the main analytic sample in this study. We estimate each model using cluster standard errors and generally using panel weights corresponding to the 1992 wave of data, although some analyses require panel weights corresponding to the 2014 wave.

We want to estimate the effect of socioeconomic variables for different school transitions, and we are particularly interested in how these effects change when conditioning on confounders between successive school transitions. Accordingly, for each transition, we use three different sets of covariates, each with successively more factors that predict a student's educational trajectory. The first consists of only the demographic variables, including the socioeconomic variables (parental education, family income, parental SEI, and sibship size). The second consists of the demographic variables as well as the cognitive variables. The third consists of all variables: demographic, cognitive, and noncognitive.

\subsection{Missing data}

We delete cases that are missing in any of the outcomes. Percentages of missing observations in the explanatory variables range from $0 \%$ (race, gender) to $25 \%$ (family income). To handle missingness in the explanatory variables, we use multivariate imputation by chained equations. We conduct ten imputations, using all the outcome and explanatory variables detailed above as 
well as a set of auxiliary variables ${ }^{2}$ from both waves 1 and 2 . Because many of the continuous variables appear non-normally distributed, we impute continuous variables using Predictive Mean Matching rather than basic linear regression.

\subsection{Two-Level Regression}

To assess whether SES coefficients wane across transitions, we use a two-level regression approach. This involves three steps:

- (Step 1, "level-1") For each schooling transition, obtain SES coefficients from the LRM.

- (Step 2, "level-2") Code the transitions as 0 (high school attainment) to 4 (grad school attainment). Take the coefficients from Step 1 and regress them on their corresponding transition, using variance weighted least squares with the standard error of each coefficient as a weight.

- (Step 3) Interpret the level-2 slope. If it is negative, then the coefficients wane. If it is positive, then the coefficients grow. If it is practically zero, then the coefficients are stable.

The linear level-2 regressions are a heuristic meant to quantify the overall tendency of SES effects to wane across the five transitions. The SES effects may vary nonlinearly with the transitions, but the purpose is to assess if the SES effects go down on average, rather than to find a model that precisely fits these potential nonlinearities. We focus on SES as measured by parental education and family income and do not present results for which parental SEI and sibship size are the socioeconomic variables of interest, but these results are available upon request. All conclusions we present below also hold in the case of parental SEI and sibship size.

\footnotetext{
${ }^{2}$ Namely: 8-point family income at wave 2, self-report of high school grades at waves 1 and 2, locus of control at wave 2 , self-esteem at wave 2 , and effort at wave 2 .
} 


\section{Results}

\subsection{Selective attrition}

Table 2 demonstrates that the sample of respondents becomes increasingly advantaged when restricting it to those making each successively higher transition. For example, on average, those who attained a graduate or professional degree have parents with about 2.5 more years of education than the parents of those in the original sample of 10th graders. Table 3 demonstrates that the disadvantaged persons who advance in their education are a bit more steeply selected along cognitive skills than advantaged persons. For example, the high school GPA gap between people with low and high parental education for the original sample of 10 th graders is 0.3 grade points, but is only 0.1 grade points for the sample who attained a graduate or professional degree. The gap is even smaller at the college attainment level, where it is virtually nonexistent. For most cognitive variables, the gap between advantaged and disadvantaged people is smallest at the college attainment level, which may help explain the apparent null effect of social origins on the labor market outcomes of terminal bachelor's degree holders despite the importance of social origins among those with a graduate or professional degree (Torche, 2011). Finally, Table 3 also shows that the gap in noncognitive skills substantially narrows for successively higher educational transitions, in some cases even shifting in favor of the people with low parental education. A notable case is effort. People with high parental education in the original sample of 10th graders have an effort advantage of 0.15 standard deviations, but have an effort disadvantage of 0.05 standard deviations in the sample of those who attained a graduate or professional degree. In sum, attrition is mostly selective: the gap between advantaged and disadvantaged people in cognitive and noncognitive skills tends to shrink at successively higher 
levels of education. Still, this is only suggestive evidence of selective attrition bias, since there can be selective attrition without substantial bias.

\subsection{Hypothesis 1: Before conditioning on cognitive and noncognitive skills, the} estimated effect of socioeconomic variables wanes across transitions

The pattern of coefficients shown in Table 4 is generally consistent with Hypothesis (1), with a few important exceptions. Table 4 shows coefficients for socioeconomic variables from each $\mathrm{LRM}^{3}$. Figure 1 plots the level-1 parental education coefficients for each transition along with the level-2 regression lines ${ }^{4}$. Inspecting the solid regression line in Figure 1, it is clear that in the aggregate the effect of parental education gets closer to zero for higher transitions. However, the circular points in Figure 1, representing the effect of parental education at each transition, show that this pattern is not universal. The effect of parental education is greater at college entry than at high school attainment. Family income coefficients display a similar pattern (Figure 2). These results are at odds with Mare's (1980) finding of universally waning coefficients but lend credence to Lucas's (1996) argument that SES became more important for college entry between Mare's cohort and the High School and Beyond 1980 sophomore cohort, who according to Lucas entered adulthood under a hostile regime of Reagan-era policies that made college less affordable for low-income students.

\subsection{Hypothesis 2: Conditioning on cognitive and noncognitive skills adjusts for a substantial share of selection attrition bias, yielding estimated SES effects that do not attenuate across transitions.}

\footnotetext{
${ }^{3}$ Full model output from all LRMs is available in the online supplement.

${ }^{4}$ Table A.2 gives the slopes of the level-2 regression lines corresponding to parental education and family income.
} 
Even though there is marked selective attrition along both cognitive and noncognitive variables (Table 3), we find that only the omission of cognitive variables contributes to selective attrition bias; omitting noncognitive skills does not induce bias, above and beyond the bias corresponding to cognitive skills. With cognitive covariates, the level-2 regression line for parental education is flatter than the level-2 regression line from the models without cognitive covariates, hence omitting cognitive variables induces selective attrition bias (Figure 1). Therefore, failing to control for cognitive skills leads to exaggerated claims of late-stage egalitarianism.

Omitting available measures of noncognitive variables, however, does not induce selective attrition bias net of cognitive skills, since the level-2 regression lines from the models with noncognitive covariates in Figures 1 and 2 are virtually identical to the lines from the models without. Net of demographic characteristics and cognitive skills, noncognitive skills are not outstanding predictors of schooling transitions ${ }^{5}$. Across transitions, coefficients for locus of control and self-esteem tend to be statistically and practically insignificant. Coefficients for effort tend to be significant, ranging from -0.037 at grad school entry to 0.316 at high school attainment, but the estimated effect of this one skill is meager compared to the combined effect of all measured cognitive skills.

Perhaps the point estimates are virtually the same after controlling for the noncognitive skills simply because cognitive skills capture all of the variance that noncognitive skills can capture on their own. For example, effort may have a strong influence on educational attainment but this influence may be mediated by the effect of effort on high school GPA. To test this theory, we estimate models with just demographic and noncognitive covariates. The estimates for this covariate set are closer to the estimates with only demographic covariates than they are to

\footnotetext{
${ }^{5}$ Full model output is available in the online supplement.
} 
the estimates with demographic and cognitive covariates (Figures A.1 and A.2 in the Appendix). Therefore, the noncognitive variables do not induce much selective attrition bias even when considered on their own.

Does previously unobserved conscientiousness induce selective attrition bias? We attempt to answer this question by running a set of LRMs with an additional covariate, namely conscientiousness as measured in 2014, meant to be a proxy for conscientiousness in 1980. While the effort scale probably captures some aspects of conscientiousness, adding an explicit measure of conscientiousness may elucidate some selective attrition bias that would otherwise go uncaptured. However, this specification suffers from a reduction in power because only a fraction of the original 1980 sample took the long form 2014 questionnaire. Perhaps more importantly, conscientiousness measured around age 50 may not be a strong proxy for conscientiousness around age 16; Hampson and Goldberg (2006) estimate a stability coefficient of 0.25 for conscientiousness between elementary school and age $\sim 50$. As it turns out, even after including 2014 conscientiousness as a covariate, SES effects are practically the same with and without noncognitive covariates. Figure 3 illustrates this result in the case of family income: the level-2 regression line from the models with noncognitive covariates is no flatter than the level-2 regression line from the models without. The same is true of parental education (Figures 4). We suspect that the 2014 measure of conscientiousness fails to flatten the trends because it is only moderately related to conscientiousness in adolescence ${ }^{6}$. The lack of selective attrition bias due to this measure of conscientiousness is of interest in its own right, though. Given mounting evidence that conscientiousness affects educational attainment (Burks et al., 2015; Hampson et

\footnotetext{
${ }^{6}$ In case the apparent irrelevance of consciousness arose because the effort scale already accounted for all of the effect of consciousness, we computed the Pearson correlation between consciousness in 2014 and effort in 1980 and found it to be only 0.123 .
} 
al., 2007; Heckman \& Kautz, 2012; Kaiser \& Diewald, 2014; Lee \& Ohtake, 2012; Lundberg, 2013; Trapmann et al., 2007), this result is surprising unless middle-aged conscientiousness is a poor proxy for conscientiousness in adolescence. The available measure of conscientiousness has only a tenuous conditional association with school transition probabilities. Conscientiousness coefficients range from -0.05 to 0.12 depending on the school transition, and none of these coefficients is statistically significant at the 0.05 level $^{7}$.

At least with respect to the cognitive and noncognitive skills that we observe, we cannot claim that selective attrition bias fully explains the waning coefficients pattern. Even after controlling for these skills, there is a general slight pattern of waning coefficients. The dotted level-2 regression lines in Figures 1-4 show that SES effects generally trend towards zero for successively higher transitions even with cognitive and noncognitive covariates, though the trend is slight. However, the level-2 regression lines obscure the important exceptions to this pattern. Notably, we reconfirm Lucas's (1996) finding that SES has a larger effect on college entry than on high school attainment. Family income and parental education are more influential on college entry than on any other transition (Figures 1-2, triangular points), and the effect of each is substantial. The estimated family income and parental education coefficients are, respectively, 0.019 and 0.155 . Hence, holding constant all observed demographic, cognitive, and noncognitive covariates, a family income increase of $\$ 10,000$ (measured in 1980 dollars) is associated with a $20 \%$ increase in the odds of entering college given high school attainment, and a 4 year increase

\footnotetext{
${ }^{7}$ Full model output is available in the online supplement.
} 
in parental education is associated with an $85 \%$ increase in odds ${ }^{8}$. Educational attainment is not egalitarian in its late stages ${ }^{9}$.

\subsection{Robustness to alternative college entry definition}

In our preferred models, we choose to have only one pathway for college entry and operationalize this as having ever entered a baccalaureate college. It is not immediately obvious whether this definition makes more theoretical sense than a definition of college entry that includes entry into two-year colleges. Mare's (1980) conceptualization of educational attainment rests on the sequential nature of school transitions, i.e., transition $j-1$ is a strict prerequisite to transition $j$. For Mare, educational attainment is one non-winding path, starting at school entry and ending at postgraduate education, with a decision to continue at each milestone. While this was more or less the case for Mare's sample born between 1908 and 1953, the rise of two-year postsecondary enrollment has made this type of transition more important to consider. By the 1980s, more people were entering a two-year college and either dropping out, terminating their schooling with an Associate's degree, or transferring to a baccalaureate college before (or after) receiving an Associate's degree. While research on horizontal stratification (e.g., Karlson, 2011; Lucas, 2001) provides a framework to investigate these different pathways, we focus on vertical stratification because we seek to build on Mare's work, and therefore we must devise a hierarchy of schooling transitions based on quantitative differences in schooling. Thus, our preferred

\footnotetext{
${ }^{8}$ These estimates are very robust. We use Frank and Xu's (2017) sensitivity analysis to estimate that a confounding variable would have to be correlated at 0.3 with both parental education and college entry, conditional on all covariates, to drop the coefficient down to statistical insignificance. This correlation corresponds to an impact of 0.09 , which is far greater than the maximum impact of the observed variables ( 0.04 , parental SEI). A confounding variable would have to be conditionally correlated at 0.21 with both family income and college entry to drop the coefficient down to statistical insignificance. This correlation corresponds to an impact of 0.05 , compared to the maximum impact of the observed variables of 0.03 (parental SEI).

${ }^{9}$ For both hypotheses, the substantive conclusions are the same when we stratify the sample by sex.
} 
definition of college entry is entry into a baccalaureate college, since this definition allows us to have one clean pathway for which each transition is a strict prerequisite to the next.

Our definition of college entry has the drawback of conflating high school graduates with persons whose highest educational credential is an Associate's degree, thus we test whether our results change under an alternative definition of college entry based on whether the individual entered either a baccalaureate or a two-year college. Using the alternative college entry definition does not alter the essence of our findings. Table A.3 in the Appendix shows that the results with respect to selective attrition bias are virtually identical under the alternative definition. The main difference that arises is that the college entry coefficients are slightly attenuated and the college (i.e., baccalaureate) attainment coefficients increase in magnitude compared to the coefficients under our preferred definition of college entry. Both of these changes occur because low-SES college attenders have a higher propensity to attend two-year colleges than high-SES college attenders. Nevertheless, these results are still consistent with the essential point that education is not egalitarian in its late stages.

\subsection{Educational inequality later in the life-course}

Does the effect of SES on school transitions look the same later in the life-course, after individuals have had several decades to make further transitions? To address this question, we estimate a set of LRMs with 2014 educational attainment data rather than 1992 educational attainment. Taking a longer view, first, does little to change our understanding of the extent of selective attrition bias induced by ignoring variation in noncognitive skills and, second, reinforces the finding that SES is more associated with college entry than high school attainment (Figures 5 and 6, exact coefficients in Table A.4). However, taking a longer view yields a 
slightly larger estimated effect of SES on college attainment and slightly lower estimated effect on college entry. The pattern is driven by people from low-SES backgrounds who attend college later in adulthood but drop out. Those who drop out later in adulthood are more disadvantaged than those who drop out early in adulthood. For example, among those who attended college but did not complete between 1980 and 1992, the average income for the student's family in 1980 was $\$ 23,000$. In contrast, among those who attended college for the first time between 1993 and 2014 but had not completed, the average was $\$ 18,500$. This difference equals about one third of a standard deviation. The patterns are similar for parental education, parental SEI, and sibship size (Table 5). Hence, time does not erase the socioeconomic inequality that initially exists for this cohort. When considering the cohort's education levels at midlife, college entry remains a highly unequal transition and college attainment becomes an especially unequal transition.

While college entry and attainment are stubbornly unequal transitions over the lifecourse, our findings point to equality at the very latest stage of schooling. Among middle-aged adults who at some point entered graduate school, parental education and family income of origin seem to have no bearing on attainment of a graduate degree (Figures 5 and 6). Graduate school entrants of modest social origins "catch up" to their more advantaged counterparts as they age, even though the odds may have been against them to get to that point.

\section{Conclusion}

The waning coefficients finding (Mare, 1980) has captured the attention of social scientists in part because it has real policy implications. If socioeconomic advantage truly declines for successively higher transitions, then public funding is better spent on alleviating early rather than late educational disparities. However, the coefficients for later educational transitions may be 
downwardly biased due to unobserved, selective attrition that leaves low-SES people holding more atypically high cognitive and noncognitive skills (Cameron \& Heckman, 1998; Mare, 1980). Here, we have assessed the extent of selective attrition bias due to noncognitive variables. The presence of this form of bias contradicts what Lucas, Fucella, and Berends (2011, pg. 283) call "the claim of late stage egalitarianism."

Analyzing data from the High School and Beyond 1980 high school sophomore cohort, we find that marginal SES associations across schooling transitions generally wane, though this pattern is not universal; omitting cognitive skills induces selective attrition bias in the SES effect estimates, but omitting noncognitive skills does not induce additional bias; and that in the aggregate, SES effects wane slightly after controlling for cognitive and noncognitive skills, but socioeconomic status appears especially important at the college entry transition.

Socioeconomically disadvantaged and advantaged individuals in this cohort do not fare similarly in the educational sphere, even once they have finished high school. Hence, any effort to focus attention solely on early interventions misses inequality at later stages. Socioeconomic advantage appears especially strong at the point of college entry. We find that net of high school attainment and demographic, cognitive, and noncognitive covariates, a \$10,000 increase in (1980) family income is associated with a $20 \%$ increase in the odds of entering college given high school completion, and a four-year increase in parental education is associated with an $85 \%$ increase in these odds. The transitions at later stages are thus far from equal.

Even though estimated SES effects on educational transitions are biased when not controlling for cognitive skills, noncognitive skills appear to contribute little of anything to this bias. This result is surprising given the established importance of noncognitive skills for educational success. Scholars have speculated that unobserved heterogeneity in noncognitive 
skills could help explain the waning coefficients finding (Cameron \& Heckman, 1998; Holm \& Jaeger, 2011), but the findings of this study fail to support this hypothesis. Additional noncognitive skills that we do not observe may play a role, but the skills we do observe capture much of the variation in these other skills (Judge, Erez, Bono, \& Thoresen, 2002; Nakaya, Oshio, \& Kaneko, 2006). Our findings, then, could reflect a legitimate lack of selective attrition bias due to noncognitive skills, or flawed measurement. If selective attrition along noncognitive skills truly does not help explain the waning coefficients finding, researchers should reconsider why coefficients wane in so many contexts. Selective attrition by noncognitive skills has been a leading explanation, but Müller and Karle's (1993) life-course perspective provides a possible alternative: the effect of SES might wane as parents' influence on habits, tastes, and material richness weakens. Perhaps noncognitive skills do help explain the waning coefficients finding, though, and the noncognitive skills at our disposal are error-prone. In this case, stratification researchers should gather better longitudinal data containing noncognitive skills. We suspect that our findings would be different with better measures of conscientiousness in particular. Ample research points to the importance of conscientiousness for educational attainment, but most of this research measures conscientiousness prior to or contemporaneously with educational attainment. Our measure of conscientiousness comes well after most respondents had finished their education. As better longitudinal data become available, future research might replicate this study using more appropriate measures of conscientiousness.

\section{References}

Almlund, M., Duckworth, A. L., Heckman, J. J., \& Kautz, T. D. (2011). Personality psychology and economics (No. w16822). National Bureau of Economic Research. 
Ashenfelter, O., \& Rouse, C. (1998). Income, schooling, and ability: Evidence from a new sample of identical twins. The Quarterly Journal of Economics, 113(1), 253-284.

Bailey, M. J., \& Dynarski, S. M. (2011). Inequality in postsecondary education. In Whither Opportunity?: Rising Inequality and the Uncertain Life Chances of Low-Income Children (pp. 117-131). Russell Sage Foundation.

Bar-Tal, D., \& Bar-Zohar, Y. (1977). The relationship between perception of locus of control and academic achievement: Review and some educational implications. Contemporary Educational Psychology, 2(2), 181-199.

Blau, P. M., \& Duncan, O. D. The American occupational structure. New York: Wiley, 1967.

Borghans, L., Duckworth, A. L., Heckman, J. J., \& Ter Weel, B. (2008). The economics and psychology of personality traits. Journal of human Resources, 43(4), 972-1059.

Buis, M. L. (2011). The consequences of unobserved heterogeneity in a sequential logit model. Research in Social Stratification and Mobility, 29(3), 247-262.

Burks, S. V., Lewis, C., Kivi, P. A., Wiener, A., Anderson, J. E., Götte, L., ... \& Rustichini, A. (2015). Cognitive skills, personality, and economic preferences in collegiate success. Journal of Economic Behavior \& Organization, 115, 30-44. 
Cameron, S.V. and J.J. Heckman. 1998. "Life Cycle Schooling and Dynamic Selection Bias: Models and Evidence for Five Cohorts of American Males." The Journal of Political Economy 106:262-333.

Cobb-Clark, D. A., \& Schurer, S. (2012). The stability of big-five personality traits. Economics Letters, 115(1), 11-15.

Coleman, J. S., \& Department of Health USA. (1966). Equality of educational opportunity (Vol. 2). Washington, DC: US Department of Health, Education, and Welfare, Office of Education.

Cutler, D. M., \& Lleras-Muney, A. (2006). Education and health: evaluating theories and evidence (No. w12352). National bureau of economic research.

Duckworth, A. L., \& Seligman, M. E. (2005). Self-discipline outdoes IQ in predicting academic performance of adolescents. Psychological science, 16(12), 939-944.

Duckworth, A. L., Peterson, C., Matthews, M. D., \& Kelly, D. R. (2007). Grit: perseverance and passion for long-term goals. Journal of personality and social psychology, 92(6), 1087.

Elwert, F., \& Winship, C. (2014). Endogenous selection bias: The problem of conditioning on a collider variable. Annual Review of Sociology, 40, 31-53. 
Farkas, G. (2003). Cognitive skills and noncognitive traits and behaviors in stratification processes. Annual review of sociology, 29(1), 541-562.

Finn, J. D., \& Rock, D. A. (1997). Academic success among students at risk for school failure. Journal of applied psychology, 82(2), 221.

Flouri, E. (2006). Parental interest in children's education, children's self-esteem and locus of control, and later educational attainment: Twenty-six year follow-up of the 1970 British Birth Cohort. British journal of Educational psychology, 76(1), 41-55.

Frank, K. A., \& Xu, R. (2017). KONFOUND: Stata module to quantify robustness of causal inferences. Statistical Software Components.

Gamoran, A. (2001). American schooling and educational inequality: A forecast for the $21^{\text {st }}$ century. Sociology of education, 135-153.

Hampson, S. E., \& Goldberg, L. R. (2006). A first large cohort study of personality trait stability over the 40 years between elementary school and midlife. Journal of personality and social psychology, 91(4), 763.

Hampson, S. E., Goldberg, L. R., Vogt, T. M., \& Dubanoski, J. P. (2007). Mechanisms by which childhood personality traits influence adult health status: educational attainment and 
healthy behaviors. Health psychology, 26(1), 121.

Heckman, J. J., \& Kautz, T. (2012). Hard evidence on soft skills. Labour economics, 19(4), 451464.

Hertz, T., Jayasundera, T., Piraino, P., Selcuk, S., Smith, N., \& Verashchagina, A. (2007). The inheritance of educational inequality: International comparisons and fifty-year trends. The BE Journal of Economic Analysis \& Policy, 7(2).

Hodge, R.W. 1981. "The measurement of occupational status." Social Science Research 10:396415.

Holm, A., \& Jæger, M. M. (2011). Dealing with selection bias in educational transition models: The bivariate probit selection model. Research in Social Stratification and Mobility, 29(3), 311-322.

Hout, M. (1988). More universalism, less structural mobility: The American occupational structure in the 1980s. American Journal of sociology, 93(6), 1358-1400.

Hout, M., \& Janus, A. (2011). Educational mobility in the United States since the 1930s. In Whither Opportunity?: Rising Inequality, Schools, and Children's Life Chances (pp. 165-185). Russell Sage Foundation. 
Hout, M., T.W. Smith, and P.V. Marsden. 2015. "Prestige and Socioeconomic Scores for the 2010 Census Codes." Methodological Report MR124, Chicago, NORC. http://gss.norc.org/get-documentation/methodological-reports

Judge, T. A., Erez, A., Bono, J. E., \& Thoresen, C. J. (2002). Are measures of self-esteem, neuroticism, locus of control, and generalized self-efficacy indicators of a common core construct?. Journal of personality and social psychology, 83(3), 693.

Kaiser, T., \& Diewald, M. (2014). Social origin, conscientiousness, and school grades: Does early socialization of the characteristics orderliness and focus contribute to the reproduction of social inequality?. Research in Social Stratification and Mobility, 38, 93105.

Karlson, K. B. (2011). Multiple paths in educational transitions: A multinomial transition model with unobserved heterogeneity. Research in Social Stratification and Mobility, 29(3), 323-341.

Lee, S., \& Ohtake, F. (2012). The Effect of Personality Traits and Behavioral Characteristics on Schooling, Earnings and Career Promotion. Journal of Behavioral Economics and Finance, 5, 231-238.

Lucas, S. R. (1996). Selective attrition in a newly hostile regime: The case of 1980 sophomores. Social forces, 75(2), 511-533. 
Lucas, S. R., Fucella, P. N., \& Berends, M. (2011). A neo-classical education transitions approach: A corrected tale for three cohorts. Research in Social Stratification and Mobility, 29(3), 263-285.

Lucas, S. R. (2001). Effectively maintained inequality: Education transitions, track mobility, and social background effects 1. American journal of sociology, 106(6), 1642-1690.

Lundberg, S. (2013). The college type: Personality and educational inequality. Journal of Labor Economics, 31(3), 421-441.

Mare, Robert D. 1980. "Social Background and School Continuation Decisions." Journal of the American Statistical Association 75:295-305.

Marsh, H. W., \& O'Mara, A. (2008). Reciprocal effects between academic self-concept, selfesteem, achievement, and attainment over seven adolescent years: Unidimensional and multidimensional perspectives of self-concept. Personality and Social Psychology Bulletin, 34(4), 542-552.

Nakaya, M., Oshio, A., \& Kaneko, H. (2006). Correlations for Adolescent Resilience Scale with big five personality traits. Psychological reports, 98(3), 927-930.

Olneck, M. R., \& Bills, D. B. (1980). What makes Sammy run? An empirical assessment of the 
Bowles-Gintis correspondence theory. American Journal of Education, 89(1), 27-61.

Plug, E., \& Vijverberg, W. (2005). Does family income matter for schooling outcomes? Using adoptees as a natural experiment. The Economic Journal,115(506), 879-906.

Raftery, A. E., \& Hout, M. (1993). Maximally maintained inequality: Expansion, reform, and opportunity in Irish education, 1921-75. Sociology of education, 41-62.

Reardon, S. F. (2011). The widening academic achievement gap between the rich and the poor: New evidence and possible explanations. In Whither Opportunity? Rising Inequality and the Uncertain Life Chances of Low-Income Children (pp. 91-116). Russell Sage Foundation.

Reed, J., Pritschet, B. L., \& Cutton, D. M. (2013). Grit, conscientiousness, and the transtheoretical model of change for exercise behavior. Journal of health psychology, $18(5), 612-619$.

Roberts, B. W. (2009). Back to the future: Personality and assessment and personality development. Journal of research in personality, 43(2), 137-145.

Roberts, B. W., \& DelVecchio, W. F. (2000). The rank-order consistency of personality traits from childhood to old age: a quantitative review of longitudinal studies. Psychological bulletin, 126(1), 3. 
Rosenberg, M. (1965). Society and the adolescent self-image (Vol. 11). Princeton, NJ: Princeton University Press.

Rosenberg, M., Schooler, C., Schoenbach, C., \& Rosenberg, F. (1995). Global self-esteem and specific self-esteem: Different concepts, different outcomes. American sociological review, 141-156.

Rotter, J. B. (1966). Generalized expectancies for internal versus external control of reinforcement. Psychological monographs: General and applied, 80(1), 1.

Sewell, W. H., Haller, A. O., \& Ohlendorf, G. W. (1970). The educational and early occupational status attainment process: Replication and revision. American Sociological Review, 1014-1027.

Shavit, Y., \& Blossfeld, H. P. (1993). Persistent Inequality: Changing Educational Attainment in Thirteen Countries. Social Inequality Series. Westview Press, 5500 Central Avenue, Boulder, CO 80301-2847.

Snyder, T. D. (Ed.). (1993). 120 years of American education: A statistical portrait. DIANE Publishing.

Soto, C. J., John, O. P., Gosling, S. D., \& Potter, J. (2011). Age differences in personality traits 
from 10 to 65: Big Five domains and facets in a large cross-sectional sample. Journal of personality and social psychology, 100(2), 330.

Tam, T. (2011). Accounting for dynamic selection bias in educational transitions: The CameronHeckman latent class estimator and its generalizations. Research in Social Stratification and Mobility, 29(3), 287-310.

Thiel, H., \& Thomsen, S. L. (2013). Noncognitive skills in economics: Models, measurement, and empirical evidence. Research in economics, 67(2), 189-214.

Torche, F. (2011). Is a college degree still the great equalizer? Intergenerational mobility across levels of schooling in the United States. American Journal of Sociology, 117(3), 763-807.

Trapmann, S., Hell, B., Hirn, J. O. W., \& Schuler, H. (2007). Meta-analysis of the relationship between the Big Five and academic success at university. Zeitschrift für Psychologie/Journal of Psychology, 215(2), 132-151.

Wang, L. Y., Kick, E., Fraser, J., \& Burns, T. J. (1999). Status attainment in America: The roles of locus of control and self-esteem in educational and occupational outcomes. Sociological Spectrum, 19(3), 281-298.

Young, K., Drought, N., \& Bergstresser, J. (1937). Social and emotional adjustments of freshmen at the University of Wisconsin. American Sociological Review, 2(2), 166-177. 


\section{Tables}

Table 1. Summary of variables used in Logistic Response Models.

\section{OUTCOME VARIABLES}

High School Attainment. Indicator equal to 1 if respondent has at least attained a high school diploma or GED by 1992,0 otherwise.

College Entry. Indicator equal to 1 if respondent has at least entered a baccalaureate college by 1992, 0 otherwise.

College Attainment. Indicator equal to 1 if respondent has at least attained a baccalaureate college degree by 1992, 0 otherwise.

Grad School Entry. Indicator equal to 1 if respondent has at least entered a graduate or professional degree program by 1992, 0 otherwise.

Grad School Attainment. Indicator equal to 1 if respondent has attained a graduate or professional degree by 1992, 0 otherwise.

\section{EXPLANATORY VARIABLES}

\section{Demographic Variables}

Parental Education. The average of the highest years of schooling completed by the respondent's mother and father. Respondents report their parents' highest level of education completed (categorically) and we code each category as follows: Less than high school $=8$ years; High school $=12$ years; Some college $=14$ years; associate's degree $=14$ years; bachelor's degree $=16$ years; Master's degree or higher $=18$ years. We estimate that the typical HSB sample member's parent who completed less than high school had completed 8 grades of schooling-we assume that sample members' parents were about 25 years old in 1964 and, using National Center for Education Statistics (Snyder, 1993, pg. 18) grade completion rates for age 25+ men, we estimate the average years of schooling for those who did not finish high school. The average comes to 7.3 years, and we round up to 8 years since HSB parents are probably more educated than others in their generation, given that their children entered 10th grade. We also tried using the education level of the more educated parent but found that this specification yielded worse-performing models on the basis of F-statistics.

Family Income. Transformation of a 7-point family income scale from 1 ( $\$ 6,999$ or less) to 7 (\$38,000 or more). We take the midpoint of each response category (except for the top response category, for which we take the minimum and add the range of the previous response category) and obtain the following seven values: $\$ 3,500$, $\$ 9,500, \$ 14,000, \$ 18,000, \$ 22,500, \$ 31,500, \$ 51,000$. We divide each by 1,000 in order to measure family income in thousands of dollars.

Parental SEI. Maximum socioeconomic index (Hodge, 1981) between the respondent's parents. Respondents' free-form reports of their parents' occupations were translated into Standard Occupational Classification 2010 codes. We transformed these codes into Census 2010 occupation codes, and obtained SEI values for each Census 2010 occupation code, following Hout, Smith, and Marsden (2015). Some respondents provided a general occupational category but no free-form report. We assign these respondents a parental SEI value equal to the average SEI of example occupations within the specified general category, as listed in the survey item that asks for a general occupational category. Range: 1 to 100, higher implies greater occupational standing. We also tried using the average SEI between the two parents but found that this specification yielded worse-performing models on the basis of F-statistics.

Sibship Size. Respondent's number of siblings, reported at first follow-up (top coded at 6).

Race. Respondent's race, with response categories "Black," "White," "American Indian or Alaskan Native," "Asian or Pacific Islander," and "Other." If respondent also indicates that their "origin or descent" is "Hispanic or Spanish," the respondent's racial category is coded as "Hispanic or Spanish."

Female. Indicator equal to 1 if female, 0 otherwise.

Foreign Born. Indicator equal to 1 if born outside of the U.S., 0 otherwise. 
Mother in Home. Indicator equal to 1 if respondent lives with mother, 0 otherwise.

Father in Home. Indicator equal to 1 if respondent lives with father, 0 otherwise.

Vocabulary. Z-score on a test of vocabulary.

\section{Academic Variables}

Reading. Z-score on a test of reading ability.

Math. Z-score on a test of mathematics ability.

Science. Z-score on test of science knowledge.

Writing. Z-score on test of writing ability.

Civics. Z-score on test of civics knowledge.

High School GPA. High school GPA determined by final transcripts. On 4.0 scale.

Highest Math Course. Highest math course taken by spring of 1982. 1=Less than first year algebra, 2=First year algebra, $3=$ Geometry, $4=$ Second year algebra, $5=$ Trigonometry, $6=$ Calculus. The F-statistics from our models are not meaningfully different whether we specify highest math course as a categorical or interval-ratio variable, so we specify it as the latter for the sake of simplicity.

Noncognitive Variables

Self-Esteem. Composite score on scale derived from self-esteem items, in z-scores. Items are a subsample of those from Rosenberg's (1965) self-esteem scale.

Locus of Control. Composite score on scale derived from locus of control items, in z-scores, where a higher score denotes a more internal locus of control. Items are a subsample of those from Rotter's (1966) locus of control scale.

Effort. Composite score on scale derived from effort-related items, in z-scores. The effort-related items are selfreports from the base year of (1) average amount of time the student spends on homework per week, (2) how often the student comes to class without pencil or paper, (3) how often the student comes to class without books, (4) how often the student comes to class without her homework done, (5) how often the student is absent from school not counting instances of illness, (6) how often the student is late to school, and (7) the student's longest string of absences so far that school year. We conjecture that this scale predicts educational attainment approximately, but not precisely, how conscientiousness would if a 10th grade measure of it were available, noting that prior work has shown that scales derived from measures of effort-making behavior predict educational success (Finn \& Rock, 1997; Olneck \& Bills, 1980).

Conscientiousness (only used in small-sample analyses). Composite score on scale derived from conscientiousness items, in z-scores. Measured in 2014. Items are a subsample of those used in the Big Five Inventory. 
Table 2. Means of socioeconomic variables among those who made each educational transition (or a higher transition) by 1992 .

\begin{tabular}{lllllll}
\hline & $\begin{array}{l}\text { Enter 10th } \\
\text { Grade }\end{array}$ & $\begin{array}{l}\text { Attain High } \\
\text { School }\end{array}$ & $\begin{array}{l}\text { Enter } \\
\text { College }\end{array}$ & $\begin{array}{l}\text { Attain } \\
\text { College }\end{array}$ & $\begin{array}{l}\text { Enter Grad } \\
\text { School }\end{array}$ & $\begin{array}{l}\text { Attain Grad } \\
\text { School }\end{array}$ \\
\hline Sample Size & 10,510 & 9,640 & 4,560 & 2,890 & 840 & 440 \\
Parental Education Mean & 13.2 & 13.4 & 14.4 & 14.8 & 15.2 & 15.6 \\
Family Income Mean & $\$ 21,000$ & $\$ 22,000$ & $\$ 25,000$ & $\$ 26,000$ & $\$ 28,000$ & $\$ 29,000$ \\
Parental SEI Mean & 47.6 & 48.4 & 54.0 & 55.9 & 59.9 & 61.6 \\
Sibship Size Mean & 3.0 & 2.9 & 2.6 & 2.6 & 2.5 & 2.4 \\
\hline
\end{tabular}


Table 3. Means of academic and noncognitive variables for those who made each educational transition (or a higher transition) by 1992, by parental education (college graduate or higher vs. high school graduate or less). Categories correspond roughly to the top third and bottom third of the parental education distribution.

\begin{tabular}{|c|c|c|c|c|c|c|c|}
\hline & $\begin{array}{l}\text { Parental } \\
\text { Education }\end{array}$ & $\begin{array}{l}\text { 10th } \\
\text { Grade } \\
\text { Entry }\end{array}$ & $\begin{array}{l}\text { High } \\
\text { School } \\
\text { Attainment }\end{array}$ & $\begin{array}{l}\text { Bachelor's } \\
\text { Entry }\end{array}$ & $\begin{array}{l}\text { Bachelor's } \\
\text { Attainment }\end{array}$ & $\begin{array}{l}\text { Grad } \\
\text { School } \\
\text { Entry }\end{array}$ & $\begin{array}{l}\text { Grad } \\
\text { School } \\
\text { Attainment }\end{array}$ \\
\hline \multirow{2}{*}{$\begin{array}{l}\text { Mean Vocabulary } \\
\text { Scores }\end{array}$} & $\leq \mathrm{HS}$ & -0.24 & -0.14 & 0.27 & 0.40 & 0.49 & 0.60 \\
\hline & College + & 0.42 & 0.50 & 0.75 & 0.83 & 1.00 & 1.07 \\
\hline \multirow{2}{*}{$\begin{array}{l}\text { Mean Reading } \\
\text { Scores }\end{array}$} & $\leq \mathrm{HS}$ & -0.20 & -0.10 & 0.30 & 0.46 & 0.56 & 0.77 \\
\hline & College + & 0.36 & 0.43 & 0.70 & 0.79 & 1.02 & 1.03 \\
\hline \multirow{2}{*}{$\begin{array}{l}\text { Mean Math } \\
\text { Scores }\end{array}$} & $\leq \mathrm{HS}$ & -0.20 & -0.10 & 0.35 & 0.54 & 0.71 & 0.81 \\
\hline & College + & 0.40 & 0.47 & 0.75 & 0.87 & 1.13 & 1.20 \\
\hline \multirow{2}{*}{$\begin{array}{l}\text { Mean Science } \\
\text { Scores }\end{array}$} & $\leq \mathrm{HS}$ & -0.18 & -0.08 & 0.27 & 0.40 & 0.54 & 0.71 \\
\hline & College + & 0.31 & 0.39 & 0.61 & 0.69 & 0.86 & 0.90 \\
\hline \multirow{2}{*}{$\begin{array}{l}\text { Mean Writing } \\
\text { Scores }\end{array}$} & $\leq \mathrm{HS}$ & -0.17 & -0.06 & 0.31 & 0.46 & 0.52 & 0.63 \\
\hline & College + & 0.34 & 0.42 & 0.64 & 0.74 & 0.89 & 0.93 \\
\hline \multirow{2}{*}{$\begin{array}{l}\text { Mean Civics } \\
\text { Scores }\end{array}$} & $\leq \mathrm{HS}$ & -0.14 & -0.05 & 0.32 & 0.44 & 0.51 & 0.64 \\
\hline & College + & 0.27 & 0.33 & 0.53 & 0.61 & 0.75 & 0.80 \\
\hline \multirow{2}{*}{$\begin{array}{l}\text { Mean High } \\
\text { School GPA }\end{array}$} & $\leq \mathrm{HS}$ & 2.4 & 2.5 & 2.9 & 3.0 & 3.1 & 3.2 \\
\hline & College + & 2.7 & 2.8 & 2.9 & 3.0 & 3.2 & 3.3 \\
\hline \multirow{2}{*}{$\begin{array}{l}\text { Mean Highest } \\
\text { Math Course }\end{array}$} & $\leq \mathrm{HS}$ & 3.1 & 3.2 & 4.2 & 4.5 & 4.7 & 4.9 \\
\hline & College + & 4.2 & 4.2 & 4.6 & 4.8 & 5.1 & 5.2 \\
\hline \multirow{2}{*}{$\begin{array}{l}\text { Mean Self- } \\
\text { Concept }\end{array}$} & $\leq \mathrm{HS}$ & -0.07 & -0.04 & 0.08 & 0.11 & 0.15 & 0.28 \\
\hline & College + & 0.07 & 0.10 & 0.18 & 0.21 & 0.21 & 0.22 \\
\hline \multirow{2}{*}{$\begin{array}{l}\text { Mean Locus of } \\
\text { Control }\end{array}$} & $\leq \mathrm{HS}$ & -0.15 & -0.06 & 0.26 & 0.32 & 0.41 & 0.51 \\
\hline & College + & 0.24 & 0.29 & 0.46 & 0.51 & 0.54 & 0.52 \\
\hline \multirow[t]{2}{*}{ Mean Effort } & $\leq \mathrm{HS}$ & -0.07 & 0.05 & 0.35 & 0.47 & 0.49 & 0.60 \\
\hline & College + & 0.16 & 0.22 & 0.36 & 0.44 & 0.44 & 0.54 \\
\hline Mean & $\leq \mathrm{HS}$ & -0.01 & 0.01 & 0.03 & 0.02 & 0.01 & -0.03 \\
\hline Conscientiousness & College + & -0.01 & 0.00 & 0.00 & 0.04 & 0.08 & 0.16 \\
\hline
\end{tabular}


Table 4. Coefficients for socioeconomic variables from 15 logistic response models ( 1 for each schooling transition predicted with the listed covariate sets). Clustered standard errors are in parentheses and asterisks $\left({ }^{*}\right)$ denote statistical significance at the 0.05 level.

\begin{tabular}{l|lll}
\hline \multirow{2}{*}{ Covariate Set } & Transition & $\begin{array}{l}\text { Parental } \\
\text { Education } \\
\text { Coefficient }\end{array}$ & $\begin{array}{l}\text { Family Income } \\
\text { Coefficient }\end{array}$ \\
\hline \multirow{4}{*}{$\begin{array}{l}\text { Demographic } \\
\text { Covariates }\end{array}$} & Attain High School & $0.232^{*}(0.028)$ & $0.018^{*}(0.006)$ \\
& Enter College & $0.293^{*}(0.018)$ & $0.018^{*}(0.003)$ \\
& Attain College & $0.133^{*}(0.023)$ & $0.000(0.004)$ \\
& Enter Grad School & $0.069^{*}(0.030)$ & $0.004(0.005)$ \\
& Attain Grad School & $0.125(0.051)$ & $0.011(0.008)$ \\
\hline \multirow{4}{*}{ Covariates } & Attain High School & $0.143^{*}(0.032)$ & $0.015^{*}(0.006)$ \\
& Enter College & $0.202^{*}(0.019)$ & $0.019^{*}(0.003)$ \\
& Attain College & $0.109^{*}(0.024)$ & $0.001(0.004)$ \\
& Enter Grad School & $0.051(0.031)$ & $0.003(0.005)$ \\
& Attain Grad School & $0.128^{*}(0.053)$ & $0.013(0.009)$ \\
\hline \multirow{4}{*}{ Covariates } & Attain High School & $0.143^{*}(0.032)$ & $0.016^{*}(0.006)$ \\
& Enter College & $0.202^{*}(0.019)$ & $0.019^{*}(0.003)$ \\
& Attain College & $0.114^{*}(0.024)$ & $0.002(0.004)$ \\
& Enter Grad School & $0.051(0.031)$ & $0.004(0.005)$ \\
& Attain Grad School & $0.126^{*}(0.054)$ & $0.014(0.009)$ \\
\hline
\end{tabular}

Demographic covariates are parental education, family income, parental SEI, sibship size, race, sex, whether the respondent is foreign born, whether the mother is in the home, and whether the father is in the home. Academic covariates are high school GPA, highest math course taken in high school, and test scores in vocabulary, reading, math, science, writing, and civics. Noncognitive covariates are self-esteem, locus of control, and effort. 
Table 5. Statistics on socioeconomic status of origin for those who attended a baccalaureate college but did not attain a bachelor's degree between 1980 and 1992 (top row), and those who attended a baccalaureate college for the first time between 1993 and 2014 but had no bachelor's degree by 2014 (bottom row).

\begin{tabular}{lllll}
\hline \multirow{2}{*}{ Period } & $\begin{array}{l}\text { Mean (SD) of } \\
\text { Parental Education }\end{array}$ & $\begin{array}{l}\text { Mean }(\mathrm{SD}) \text { of Family } \\
\text { Income }\end{array}$ & $\begin{array}{l}\text { Mean (SD) of } \\
\text { Parental SEI }\end{array}$ & $\begin{array}{l}\text { Mean (SD) of Sibship } \\
\text { Size }\end{array}$ \\
\hline $1980-1992$ & $13.81(2.82)$ & $\$ 23,010(\$ 13,240)$ & $50.68(21.01)$ & $2.67(1.65)$ \\
$1993-2014$ & $12.77(2.76)$ & $\$ 18,480(\$ 9,400)$ & $45.93(19.57)$ & $3.14(1.72)$ \\
\hline
\end{tabular}




\section{Figures}

Figure 1. Level-2 regression lines of Level-1 parental education coefficients (represented by points) for each covariate set.

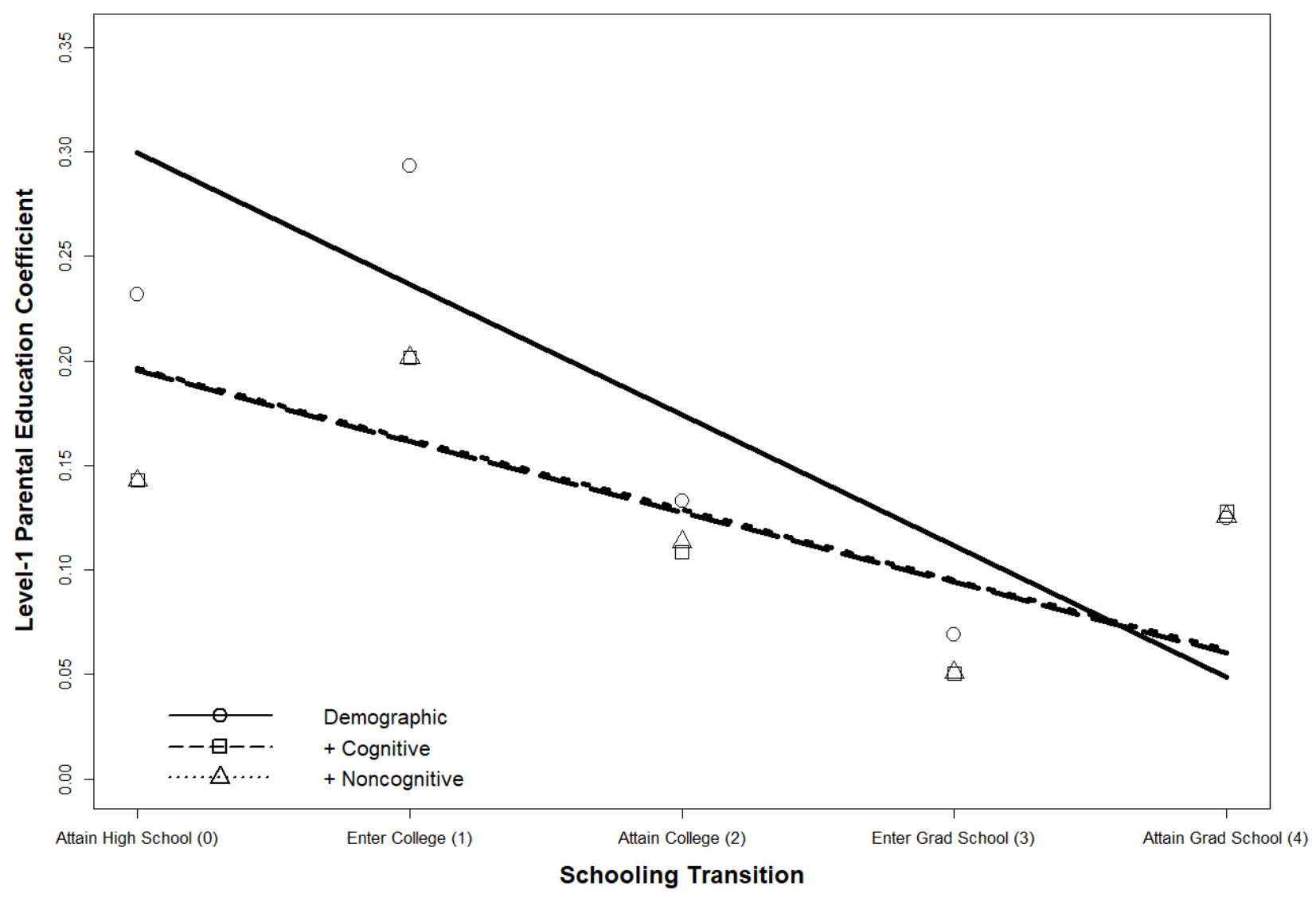


Figure 2. Level-2 regression lines of Level-1 family income coefficients (represented by points) for each covariate set.

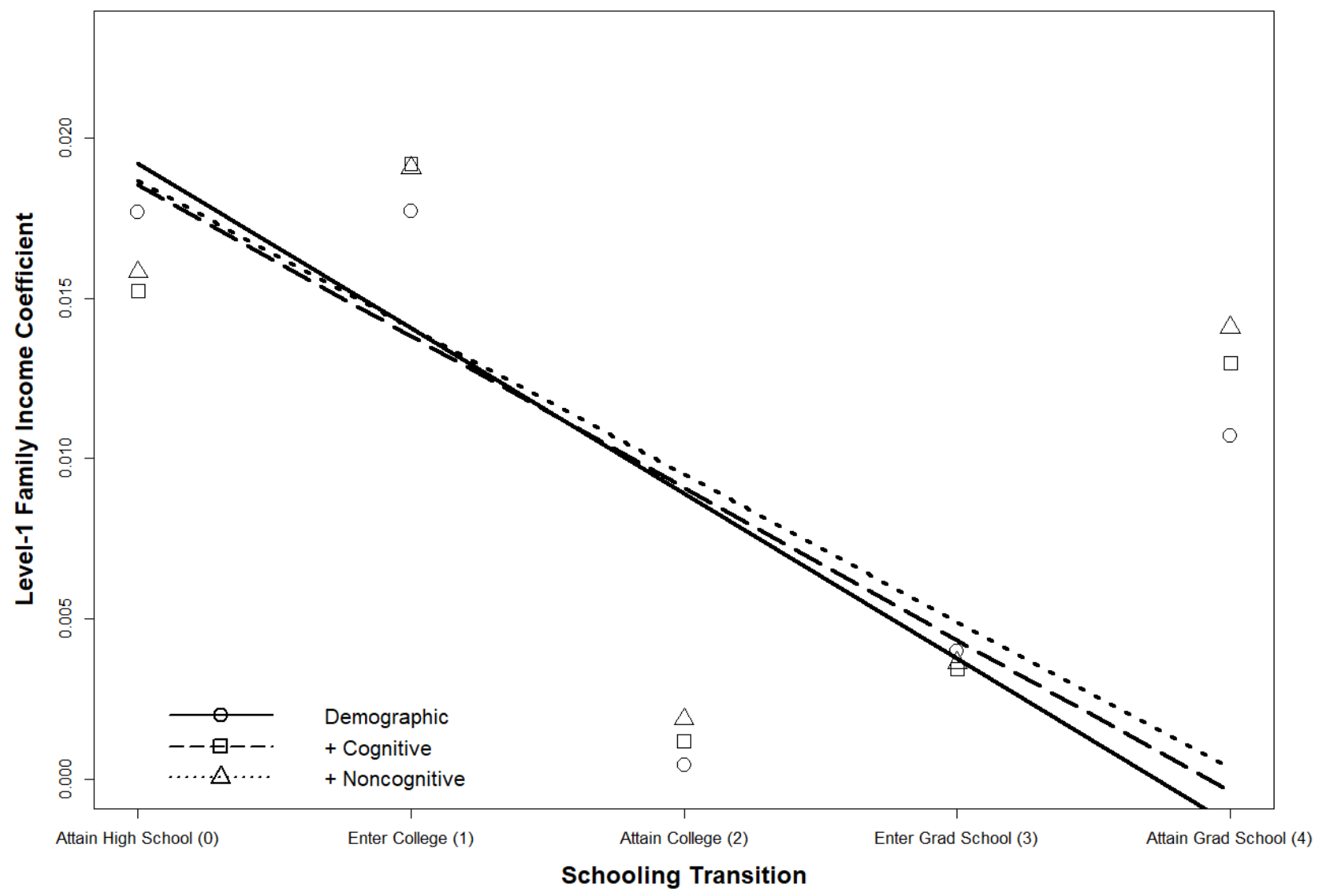


Figure 3. Level-2 regression lines of Level-1 family income coefficients (represented by points) for each covariate set, using the smaller sample of respondents who completed the long-form 2014 questionnaire and with 2014 conscientiousness as an additional noncognitive covariate.

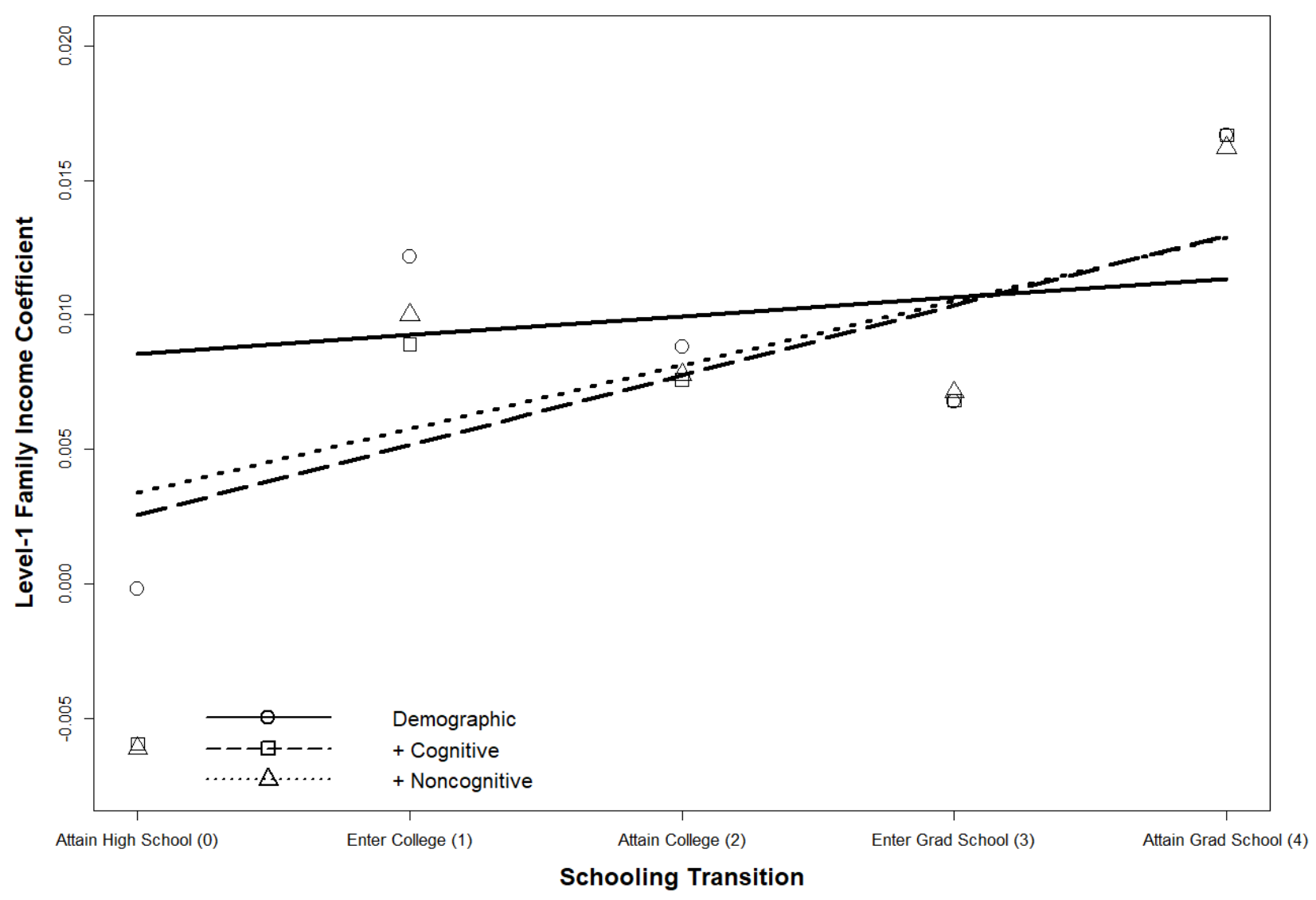


Figure 4. Level-2 regression lines of Level-1 parental education coefficients (represented by points) for each covariate set, using the smaller sample of respondents who completed the long-form 2014 questionnaire and with 2014 conscientiousness as an additional noncognitive covariate.

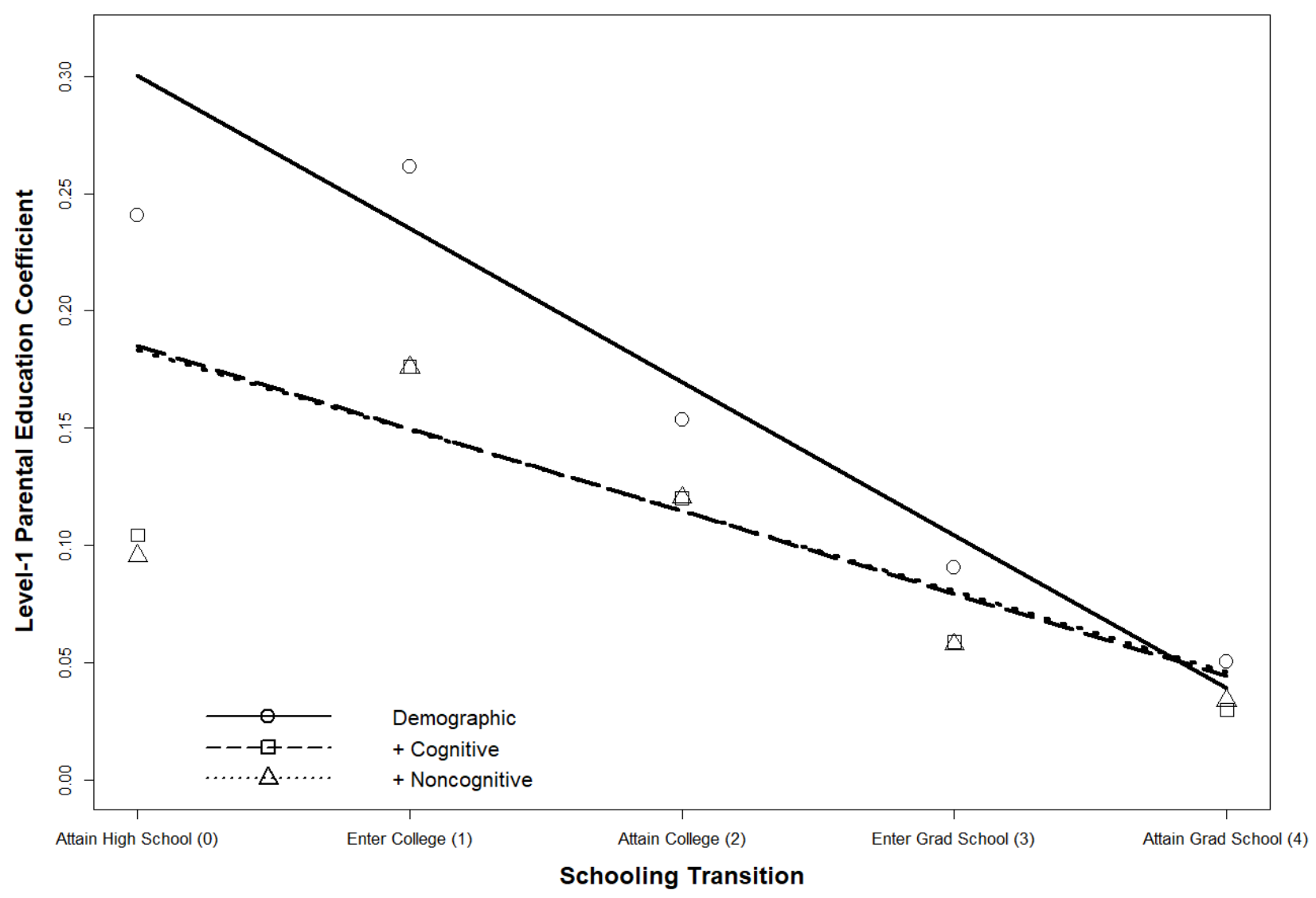


Figure 5. Level-2 regression lines of Level-1 parental education coefficients (represented by points) for each covariate set, with educational attainment determined by 2014 reports as well as 1992 reports. Results corresponding to models with only demographic and cognitive covariates are omitted because they are virtually identical to results corresponding to models with all covariates.

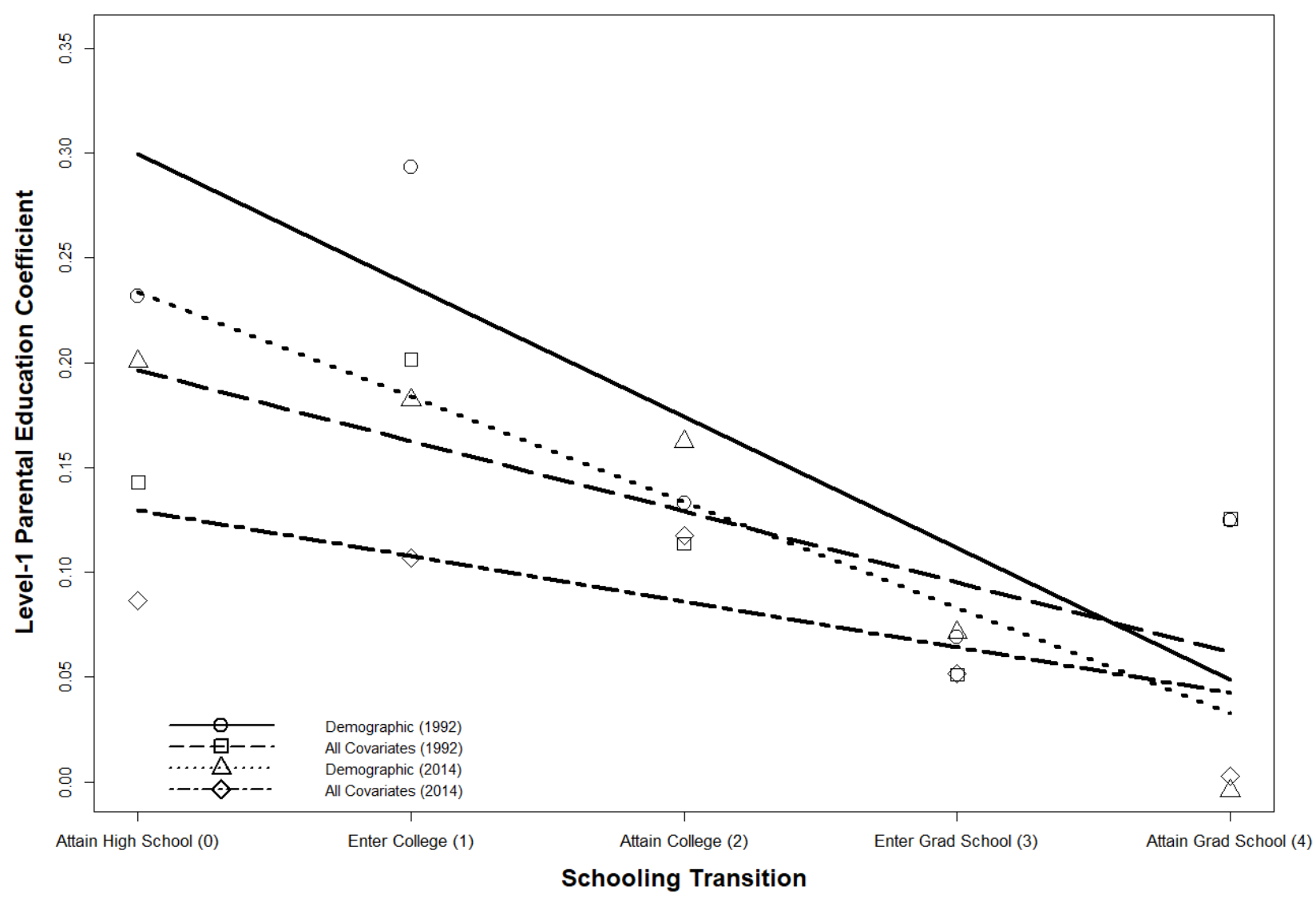


Figure 6. Level-2 regression lines of Level-1 family income coefficients (represented by points) for each covariate set, with educational attainment determined by 2014 reports as well as 1992 reports. Results corresponding to models with only demographic and cognitive covariates are omitted because they are virtually identical to results corresponding to models with all covariates.

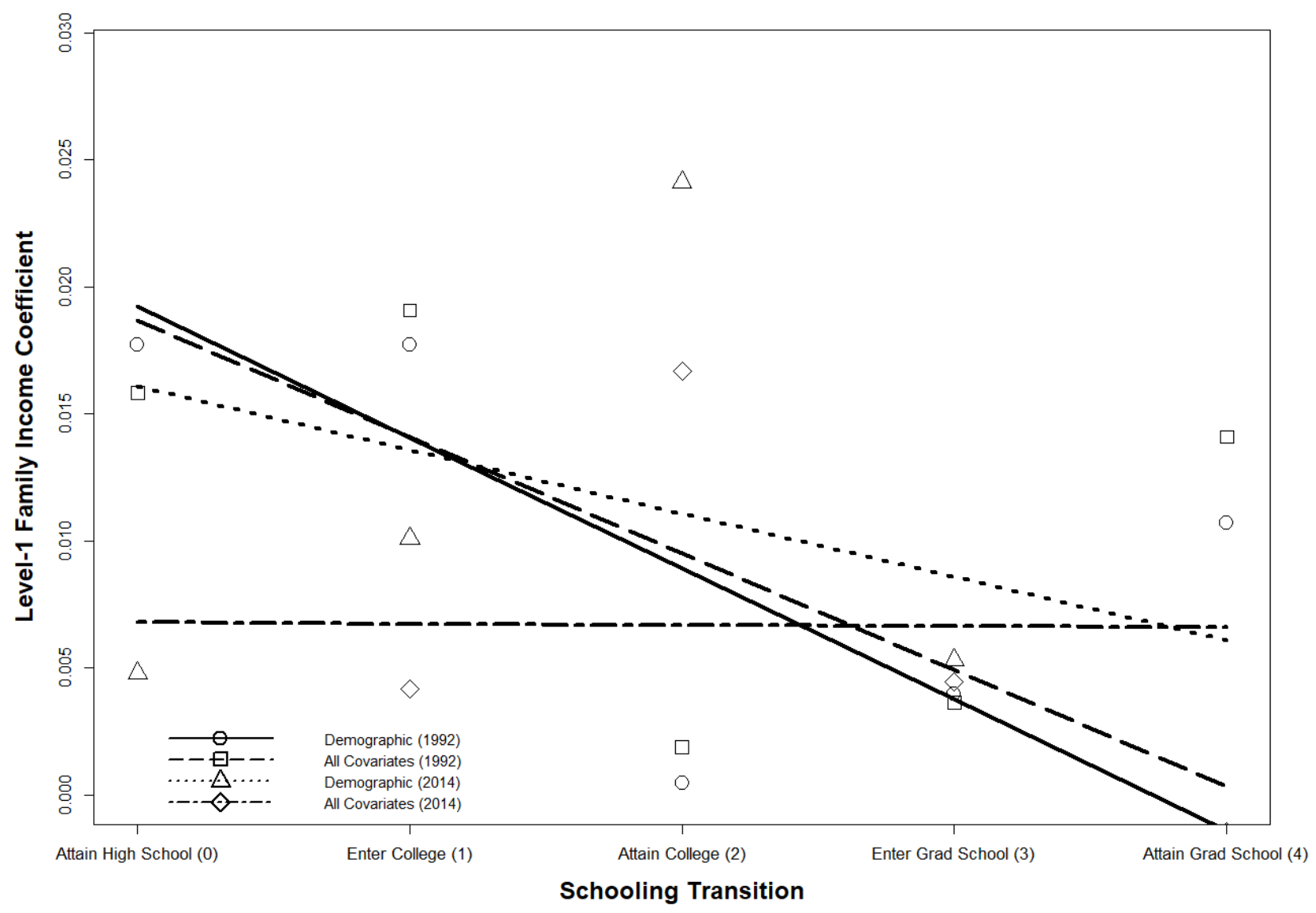




\section{Appendix Tables}

Table A.1. Descriptive statistics of measures used in this study for the main analytic sample of $10^{\text {th }}$ grade students.

\begin{tabular}{|c|c|c|}
\hline & Mean & Standard Deviation \\
\hline Family Income & $\$ 21,000$ & $\$ 13,000$ \\
\hline Parental Education & 13.2 & 3.0 \\
\hline Parental SEI & 47.6 & 20.9 \\
\hline Sibship Size & 3.0 & 1.8 \\
\hline Race (Black) & 0.13 & N/A \\
\hline Race (White) & 0.61 & $\mathrm{~N} / \mathrm{A}$ \\
\hline Race (American Indian or Alaskan Native) & 0.02 & $\mathrm{~N} / \mathrm{A}$ \\
\hline Race (Asian or Pacific Islander) & 0.03 & $\mathrm{~N} / \mathrm{A}$ \\
\hline Race (Hispanic or Spanish) & 0.21 & N/A \\
\hline Race (Other) & 0.01 & $\mathrm{~N} / \mathrm{A}$ \\
\hline Female & 0.52 & N/A \\
\hline Foreign Born & 0.07 & $\mathrm{~N} / \mathrm{A}$ \\
\hline Vocabulary Score & 0.05 & 0.99 \\
\hline Reading Score & 0.05 & 1.00 \\
\hline Math Score & 0.05 & 1.00 \\
\hline Science Score & 0.05 & 0.99 \\
\hline Writing Score & 0.06 & 0.99 \\
\hline Civics Score & 0.04 & 0.99 \\
\hline High School GPA & 2.6 & 0.7 \\
\hline Highest Math Course & 3.6 & 1.6 \\
\hline Self-Esteem & 0.01 & 0.99 \\
\hline Locus of Control & 0.04 & 0.98 \\
\hline Effort & 0.04 & 0.98 \\
\hline Conscientiousness & 0.00 & 1.00 \\
\hline
\end{tabular}


Table A.2. Level-2 slopes estimated using variance-weighted least squares regressions of socioeconomic coefficients on corresponding schooling transitions, with transitions 0 (high school attainment) to 4 (grad school attainment). Standard errors are in parentheses and asterisks $(*)$ denote statistical significance at the 0.05 level.

\begin{tabular}{lll}
\hline Covariate Set & $\begin{array}{l}\text { Parental } \\
\text { Education }\end{array}$ & Family Income \\
\hline Demographic Covariates & $-0.0626^{*}(0.011)$ & $-0.0051^{*}(0.002)$ \\
+Academic Covariates & $-0.0339(0.011)$ & $-0.0047 *(0.002)$ \\
+ Noncognitive Covariates & $-0.0337(0.011)$ & $-0.0046^{*}(0.002)$ \\
\hline
\end{tabular}


Table A.3. Coefficients for socioeconomic variables from 15 logistic response models ( 1 for each schooling transition predicted with the listed covariate sets), where college entry is defined as attendance at either a 2-year or a Baccalaureate institution. Clustered standard errors are in parentheses and asterisks $\left({ }^{*}\right)$ denote statistical significance at the 0.05 level.

\begin{tabular}{l|lll}
\hline \multirow{2}{*}{ Covariate Set } & Transition & $\begin{array}{l}\text { Parental } \\
\text { Education } \\
\text { Coefficient }\end{array}$ & $\begin{array}{l}\text { Family Income } \\
\text { Coefficient }\end{array}$ \\
\hline \multirow{4}{*}{$\begin{array}{l}\text { Demographic } \\
\text { Covariates }\end{array}$} & Attain High School & $0.232^{*}(0.028)$ & $0.018^{*}(0.006)$ \\
& Enter College & $0.240^{*}(0.16)$ & $0.014^{*}(0.003)$ \\
& Attain College & $0.213^{*}(0.020)$ & $0.008^{*}(0.003)$ \\
& Enter Grad School & $0.069^{*}(0.030)$ & $0.004(0.005)$ \\
& Attain Grad School & $0.125(0.051)$ & $0.011(0.008)$ \\
\hline \multirow{4}{*}{ Covariates } & Attain High School & $0.143^{*}(0.032)$ & $0.015^{*}(0.006)$ \\
& Enter College & $0.153^{*}(0.017)$ & $0.013^{*}(0.003)$ \\
& Attain College & $0.166^{*}(0.022)$ & $0.008^{*}(0.004)$ \\
& Enter Grad School & $0.051(0.031)$ & $0.003(0.005)$ \\
& Attain Grad School & $0.128^{*}(0.053)$ & $0.013(0.009)$ \\
\hline \multirow{4}{*}{ Covariates } & Attain High School & $0.143^{*}(0.032)$ & $0.016^{*}(0.006)$ \\
& Enter College & $0.152^{*}(0.017)$ & $0.013^{*}(0.003)$ \\
& Attain College & $0.171^{*}(0.022)$ & $0.009^{*}(0.004)$ \\
& Enter Grad School & $0.051(0.031)$ & $0.004(0.005)$ \\
& Attain Grad School & $0.126^{*}(0.054)$ & $0.014(0.009)$ \\
\hline
\end{tabular}

Demographic covariates are parental education, family income, parental SEI, sibship size, race, sex, whether the respondent is foreign born, whether the mother is in the home, and whether the father is in the home. Academic covariates are high school GPA, highest math course taken in high school, and test scores in vocabulary, reading, math, science, writing, and civics. Noncognitive covariates are self-esteem, locus of control, and effort. 
Table A.4. Coefficients for socioeconomic variables from logistic response models using 1992 educational attainment for outcome variables, compared to coefficients using 2014 educational attainment. For both educational attainment specifications, the coefficients are estimated using each listed covariate set.

\begin{tabular}{l|lrccc}
\hline \multirow{2}{*}{ Covariate Set } & \multicolumn{1}{c}{ Transition } & \multicolumn{2}{c}{$\begin{array}{c}\text { Parental } \\
\text { Education } \\
\text { Coefficient }\end{array}$} & \multicolumn{2}{c}{ Family Income } \\
& & 1992 & 2014 & 1992 & 2014 \\
\hline \multirow{4}{*}{$\begin{array}{l}\text { Demographic } \\
\text { Covariates }\end{array}$} & Attain High School & 0.232 & 0.272 & 0.018 & -0.012 \\
& Enter College & 0.293 & 0.238 & 0.018 & 0.006 \\
& Attain College & 0.133 & 0.173 & 0.000 & 0.018 \\
& Enter Grad School & 0.069 & 0.096 & 0.004 & 0.003 \\
& Attain Grad School & 0.125 & 0.043 & 0.011 & -0.004 \\
\hline \multirow{5}{*}{ Covariates } & Attain High School & 0.143 & 0.135 & 0.015 & -0.015 \\
& Enter College & 0.202 & 0.161 & 0.019 & 0.000 \\
& Attain College & 0.109 & 0.114 & 0.001 & 0.014 \\
& Enter Grad School & 0.051 & 0.073 & 0.003 & 0.002 \\
& Attain Grad School & 0.128 & 0.041 & 0.013 & -0.001 \\
\hline Covariates & Attain High School & 0.143 & 0.127 & 0.016 & -0.014 \\
& Enter College & 0.202 & 0.162 & 0.019 & 0.000 \\
& Attain College & 0.114 & 0.115 & 0.002 & 0.014 \\
& Enter Grad School & 0.051 & 0.073 & 0.004 & 0.002 \\
& Attain Grad School & 0.126 & 0.039 & 0.014 & -0.004 \\
\hline
\end{tabular}

Demographic covariates are parental education, family income, parental SEI, sibship size, race, sex, whether the respondent is foreign born, whether the mother is in the home, and whether the father is in the home. Academic covariates are high school GPA, highest math course taken in high school, and test scores in vocabulary, reading, math, science, writing, and civics. Noncognitive covariates are self-esteem, locus of control, and effort. 


\section{Appendix Figures}

Figure A.1. Level-2 regression lines of Level-1 parental education coefficients (represented by points) for each covariate set, with a fourth covariate set containing only demographic and noncognitive variables.

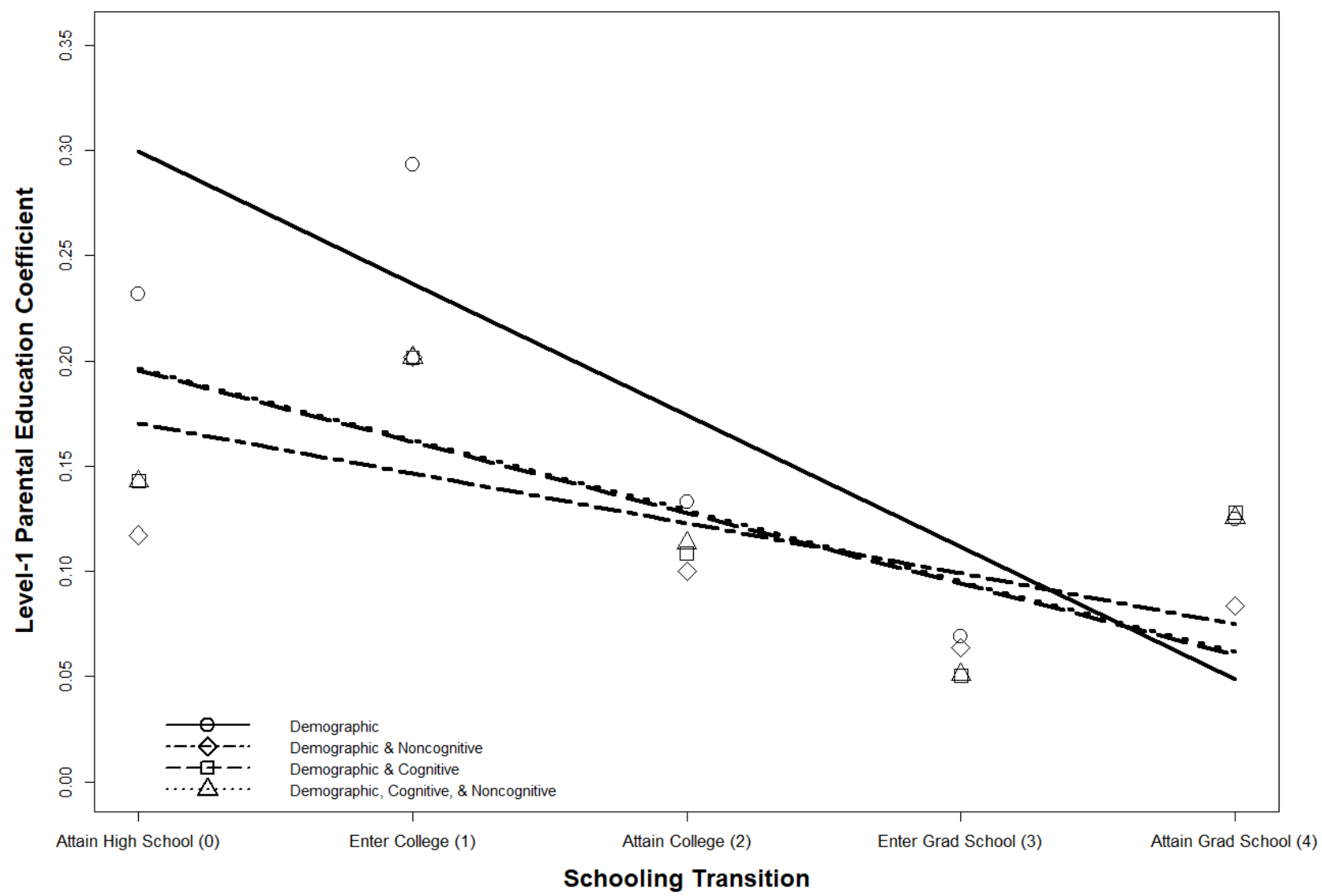


Figure A.2. Level-2 regression lines of Level-1 family income coefficients (represented by points) for each covariate set, with a fourth covariate set containing only demographic and noncognitive variables.

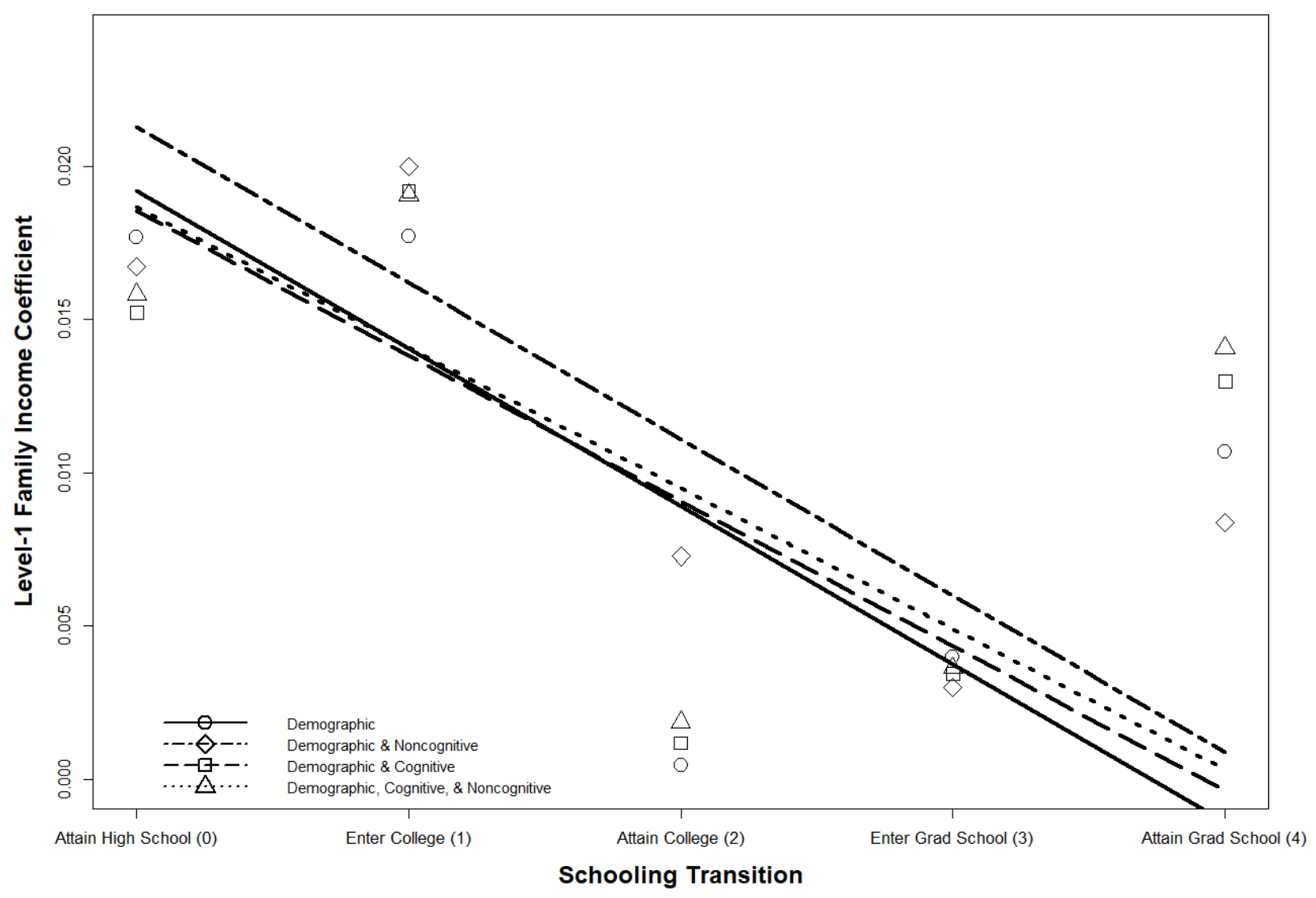


Online Supplement for "Late-Stage Educational Inequality: Can Selection on Noncognitive Skills Explain Waning Social Background Effects?"

\section{Contents}

pp. 2-27: Models Using the Main Analytic Data Set

pp. $2-5$

Outcome: High School Attainment

pp. 6-9

Outcome: College Entry

pp. $10-13$

Outcome: College Attainment

pp. $14-17$

Outcome: Grad School Entry

pp. $18-21$

Outcome: Grad School Attainment

pp. $22-24$

Outcome: Alternate College Entry

pp. $25-27$

Outcome: College Attainment Given Alternate College Entry

pp. 28-42: Models Using Smaller Sample who Completed Long-Form 2014 Questionnaire (1992

Educational Attainment)

pp. $28-30$

Outcome: High School Attainment

pp. 31-33

pp. $34-36$

pp. 37-39

Outcome: College Entry

pp. $40-42$

Outcome: College Attainment

Outcome: Grad School Entry

Outcome: Grad School Attainment

pp. 43-57: Models Using Smaller Sample who Completed Long-Form 2014 Questionnaire (2014

Educational Attainment)

pp. $43-45$

Outcome: High School Attainment

pp. $46-48$

pp. $49-51$

pp. $52-54$

Outcome: College Entry

Outcome: College Attainment

pp. $55-57$

Outcome: Grad School Entry

Outcome: Grad School Attainment 
Table S.1. Logistic response model of high school attainment estimated with demographic covariates and the main analytic data set.

\begin{tabular}{|c|c|}
\hline & High School Attainment \\
\hline Family Income & $\begin{array}{l}0.018 * * * \\
(0.006)\end{array}$ \\
\hline Parental Education & $\begin{array}{l}0.232 * * * \\
(0.028)\end{array}$ \\
\hline Parental SEI & $\begin{array}{l}0.005 \\
(0.003)\end{array}$ \\
\hline Sibship Size & $\begin{array}{l}-0.137^{* * *} \\
(0.031)\end{array}$ \\
\hline Hispanic or Spanish (ref.: White) & $\begin{array}{l}-0.394^{* * *} \\
(0.133)\end{array}$ \\
\hline American Indian or Alaskan Native (ref.: White) & $\begin{array}{l}-0.016 \\
(0.357)\end{array}$ \\
\hline Asian or Pacific Islander (ref.: White) & $\begin{array}{l}1.853 * * * \\
(0.652)\end{array}$ \\
\hline Black (ref.: White) & $\begin{array}{l}0.156 \\
(0.153)\end{array}$ \\
\hline Other (ref.: White) & $\begin{array}{l}-0.061 \\
(1.101)\end{array}$ \\
\hline Female & $\begin{array}{l}0.378^{* * *} \\
(0.096)\end{array}$ \\
\hline Foreign Born & $\begin{array}{l}0.310 \\
(0.257)\end{array}$ \\
\hline Mother in Home & $\begin{array}{l}0.763 * * * \\
(0.137)\end{array}$ \\
\hline Father in Home & $\begin{array}{l}0.401 * * * \\
(0.113)\end{array}$ \\
\hline Constant & $\begin{array}{l}-1.598^{* * *} \\
(0.346)\end{array}$ \\
\hline Observations & 10,508 \\
\hline
\end{tabular}


Table S.2. Logistic response model of high school attainment estimated with demographic and cognitive covariates and the main analytic data set.

\begin{tabular}{|c|c|}
\hline & High School Attainment \\
\hline Family Income & $\begin{array}{l}0.015 * * \\
(0.006)\end{array}$ \\
\hline Parental Education & $\begin{array}{l}0.143 * * * \\
(0.032)\end{array}$ \\
\hline Parental SEI & $\begin{array}{l}0.002 \\
(0.003)\end{array}$ \\
\hline Sibship Size & $\begin{array}{l}-0.111^{* * *} \\
(0.033)\end{array}$ \\
\hline Hispanic or Spanish (ref.: White) & $\begin{array}{l}0.209 \\
(0.148)\end{array}$ \\
\hline American Indian or Alaskan Native (ref.: White) & $\begin{array}{l}0.230 \\
(0.379)\end{array}$ \\
\hline Asian or Pacific Islander (ref.: White) & $\begin{array}{l}1.594^{* *} \\
(0.801)\end{array}$ \\
\hline Black (ref.: White) & $\begin{array}{l}0.829 * * * \\
(0.174)\end{array}$ \\
\hline Other (ref:: White) & $\begin{array}{l}1.109 \\
(1.054)\end{array}$ \\
\hline Female & $\begin{array}{l}0.062 \\
(0.116)\end{array}$ \\
\hline Foreign Born & $\begin{array}{l}0.387 * \\
(0.230)\end{array}$ \\
\hline Mother in Home & $\begin{array}{l}0.639 * * * \\
(0.162)\end{array}$ \\
\hline Father in Home & $\begin{array}{l}0.259 * * \\
(0.124)\end{array}$ \\
\hline Vocabulary & $\begin{array}{l}0.165 \\
(0.108)\end{array}$ \\
\hline Reading & $\begin{array}{l}-0.038 \\
(0.101)\end{array}$ \\
\hline Math & $\begin{array}{l}0.309 * * * \\
(0.111)\end{array}$ \\
\hline Science & $\begin{array}{l}0.111 \\
(0.098)\end{array}$ \\
\hline Writing & $\begin{array}{l}0.201 * * \\
(0.102)\end{array}$ \\
\hline Civics & $\begin{array}{l}0.040 \\
(0.083)\end{array}$ \\
\hline High School GPA & $\begin{array}{l}1.662^{* * *} \\
(0.145)\end{array}$ \\
\hline Highest Math Course & $\begin{array}{l}0.134^{* *} \\
(0.065)\end{array}$ \\
\hline Constant & $\begin{array}{l}-3.944 * * * \\
(0.526)\end{array}$ \\
\hline Observations & 10,508 \\
\hline
\end{tabular}


Table S.3. Logistic response model of high school attainment estimated with demographic, cognitive, and noncognitive covariates and the main analytic data set.

\begin{tabular}{|c|c|}
\hline & High School Attainment \\
\hline Family Income & $\begin{array}{l}0.016^{* * *} \\
(0.006)\end{array}$ \\
\hline Parental Education & $0.143 * * *$ \\
\hline Parental SEI & $\begin{array}{l}0.002 \\
(0.004)\end{array}$ \\
\hline Sibship Size & $\begin{array}{l}-0.101 * * * \\
(0.034)\end{array}$ \\
\hline Hispanic or Spanish (ref.: White) & $\begin{array}{l}0.210 \\
(0.144)\end{array}$ \\
\hline American Indian or Alaskan Native (ref:: White) & $\begin{array}{l}0.369 \\
(0.395)\end{array}$ \\
\hline Asian or Pacific Islander (ref.: White) & $\begin{array}{l}1.624 * * \\
(0.768)\end{array}$ \\
\hline Black (ref.: White) & $\begin{array}{l}0.721 * * * \\
(0.176)\end{array}$ \\
\hline Other (ref.: White) & $\begin{array}{l}1.404 \\
(1.213)\end{array}$ \\
\hline Foreign Born & $\begin{array}{l}0.459 * \\
(0.236)\end{array}$ \\
\hline Mother in Home & $\begin{array}{l}0.650 * * * \\
(0.169)\end{array}$ \\
\hline Father in Home & $\begin{array}{l}0.197 \\
(0.125)\end{array}$ \\
\hline Vocabulary & $\begin{array}{l}0.141 \\
(0.106)\end{array}$ \\
\hline Reading & $\begin{array}{l}-0.015 \\
(0.103)\end{array}$ \\
\hline Math & $\begin{array}{l}0.328 * * * \\
(0.112)\end{array}$ \\
\hline Science & $\begin{array}{l}0.073 \\
(0.100)\end{array}$ \\
\hline Writing & $\begin{array}{l}0.202^{*} \\
(0.105)\end{array}$ \\
\hline Civics & $\begin{array}{l}-0.014 \\
(0.084)\end{array}$ \\
\hline Highest Math Course & $\begin{array}{l}0.094 \\
(0.066)\end{array}$ \\
\hline Self-Esteem & $\begin{array}{l}0.044 \\
(0.052)\end{array}$ \\
\hline Locus of Control & $\begin{array}{l}0.092 \\
(0.058)\end{array}$ \\
\hline Effort & $\begin{array}{l}0.436 * * * \\
(0.055)\end{array}$ \\
\hline Constant & $\begin{array}{l}-3.207 * * * \\
(0.546)\end{array}$ \\
\hline Observations & 10,508 \\
\hline
\end{tabular}


Table S.4. Logistic response model of high school attainment estimated with demographic and noncognitive covariates and the main analytic data set.

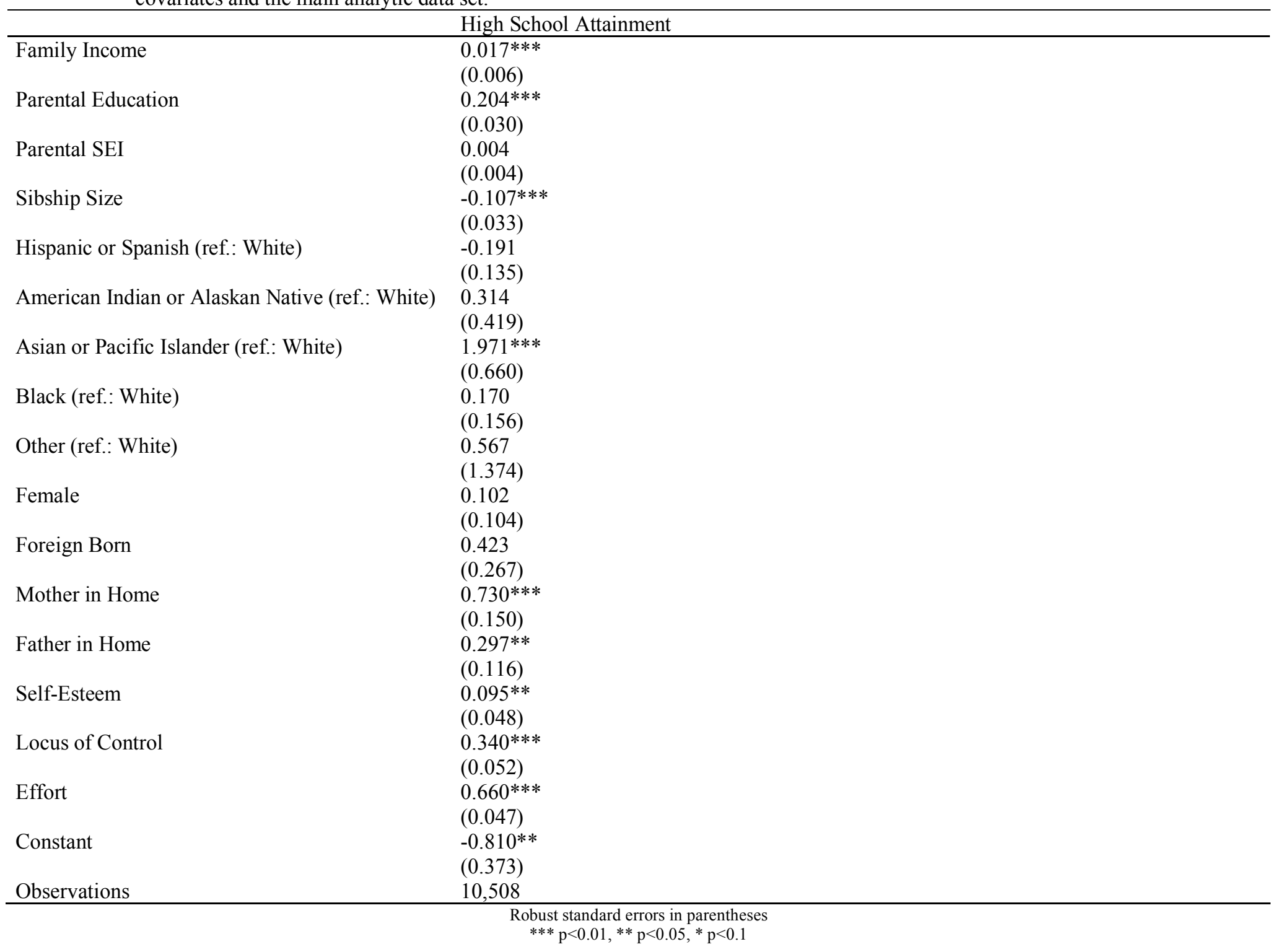


Table S.5. Logistic response model of college entry estimated with demographic covariates and the main analytic data set.

\begin{tabular}{ll}
\hline & College Entry \\
\hline Family Income & $0.018^{* * * *}$ \\
& $(0.003)$ \\
Parental Education & $0.293^{* * *}$ \\
& $(0.018)$ \\
Parental SEI & $0.007^{* * *}$ \\
& $(0.002)$ \\
Sibship Size & $-0.090^{* * *}$ \\
& $(0.019)$ \\
Hispanic or Spanish (ref.: White) & $-0.380^{* * *}$ \\
& $(0.092)$ \\
American Indian or Alaskan Native (ref.: White) & $-0.656^{* *}$ \\
& $(0.280)$ \\
Asian or Pacific Islander (ref.: White) & $0.736^{* * *}$ \\
& $(0.218)$ \\
Black (ref.: White) & -0.040 \\
& $(0.106)$ \\
Other (ref.: White) & 0.259 \\
& $(0.770)$ \\
Female & -0.070 \\
Foreign Born & $(0.058)$ \\
& 0.011 \\
Mother in Home & $(0.192)$ \\
Father in Home & $0.315^{* *}$ \\
Constant & $(0.134)$ \\
Observations & 0.055 \\
& $(0.081)$ \\
& $-4.772^{* * *}$ \\
& $(0.278)$ \\
& 9,636 \\
\hline & Robust standard errors in parentheses \\
& $* * * \mathrm{p}<0.01, * * 0.05, * \mathrm{p}<0.1$ \\
\end{tabular}


Table S.6. Logistic response model of college entry estimated with demographic and cognitive covariates and the main analytic data set.

\begin{tabular}{|c|c|}
\hline & College Entry \\
\hline Family Income & $\begin{array}{l}0.019 * * * \\
(0.003)\end{array}$ \\
\hline Parental Education & $\begin{array}{l}0.202 * * * \\
(0.019)\end{array}$ \\
\hline Parental SEI & $\begin{array}{l}0.003 \\
(0.002)\end{array}$ \\
\hline Sibship Size & $\begin{array}{l}-0.052 * * \\
(0.022)\end{array}$ \\
\hline Hispanic or Spanish (ref.: White) & $\begin{array}{l}0.340 * * * \\
(0.112)\end{array}$ \\
\hline American Indian or Alaskan Native (ref.: White) & $\begin{array}{l}-0.288 \\
(0.305)\end{array}$ \\
\hline Asian or Pacific Islander (ref.: White) & $\begin{array}{l}0.538^{* *} \\
(0.220)\end{array}$ \\
\hline Black (ref.: White) & $\begin{array}{l}0.745 * * * \\
(0.130)\end{array}$ \\
\hline Other (ref.: White) & $\begin{array}{l}1.232 \\
(1.217)\end{array}$ \\
\hline Female & $\begin{array}{l}-0.238^{* * * *} \\
(0.081)\end{array}$ \\
\hline Foreign Born & $\begin{array}{l}-0.051 \\
(0.248)\end{array}$ \\
\hline Mother in Home & $\begin{array}{l}0.091 \\
(0.167)\end{array}$ \\
\hline Father in Home & $\begin{array}{l}-0.206^{* *} \\
(0.096)\end{array}$ \\
\hline Vocabulary & $\begin{array}{l}0.199 * * * \\
(0.058)\end{array}$ \\
\hline Reading & $\begin{array}{l}0.114 * \\
(0.059)\end{array}$ \\
\hline Math & $\begin{array}{l}0.040 \\
(0.057)\end{array}$ \\
\hline Science & $\begin{array}{l}0.097^{*} \\
(0.059)\end{array}$ \\
\hline Writing & $\begin{array}{l}0.010 \\
(0.061)\end{array}$ \\
\hline Civics & $\begin{array}{l}0.153 * * * \\
(0.048)\end{array}$ \\
\hline High School GPA & $\begin{array}{l}0.836 * * * \\
(0.074)\end{array}$ \\
\hline Highest Math Course & $\begin{array}{l}0.494 * * * \\
(0.030)\end{array}$ \\
\hline Constant & $\begin{array}{l}-7.220 * * * \\
(0.400)\end{array}$ \\
\hline Observations & 9,636 \\
\hline
\end{tabular}


Table S.7. Logistic response model of college entry estimated with demographic, cognitive, and noncognitive covariates and the main analytic data set.

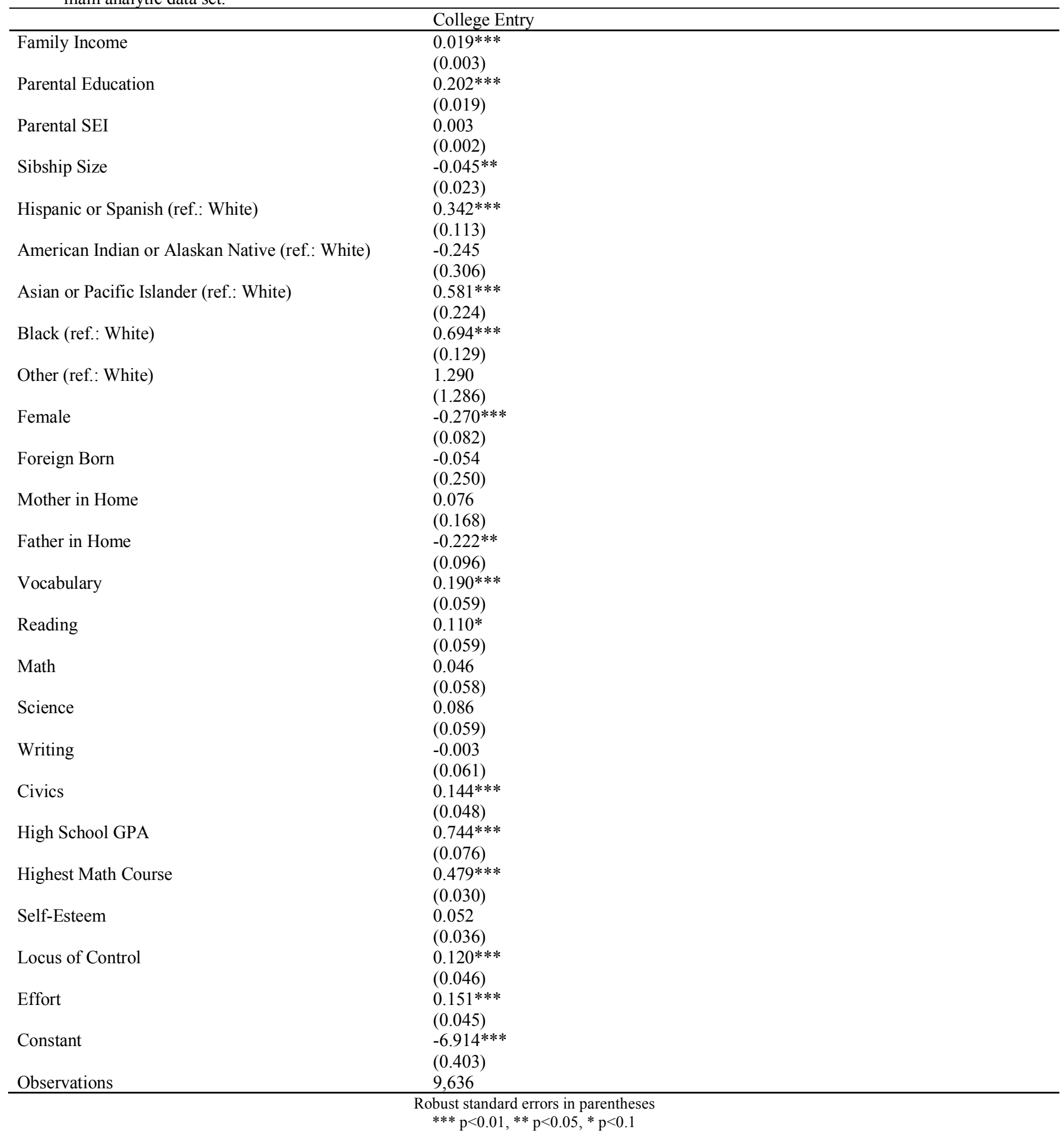


Table S.8. Logistic response model of college entry estimated with demographic and noncognitive covariates and the main analytic data set.

\begin{tabular}{|c|c|}
\hline ( & College Entry \\
\hline Family Income & $\begin{array}{l}0.018 * * * \\
(0.003)\end{array}$ \\
\hline Parental Education & $\begin{array}{l}0.274 * * * \\
(0.018)\end{array}$ \\
\hline Parental SEI & $\begin{array}{l}0.007 * * * \\
(0.002)\end{array}$ \\
\hline Sibship Size & $\begin{array}{l}-0.063^{* * *} \\
(0.020)\end{array}$ \\
\hline Hispanic or Spanish (ref.: White) & $\begin{array}{l}-0.218^{* *} \\
(0.097)\end{array}$ \\
\hline American Indian or Alaskan Native (ref.: White) & $\begin{array}{l}-0.410 \\
(0.282)\end{array}$ \\
\hline Asian or Pacific Islander (ref.: White) & $\begin{array}{l}0.855^{* * *} * \\
(0.228)\end{array}$ \\
\hline Black (ref.: White) & $\begin{array}{l}0.021 \\
(0.109)\end{array}$ \\
\hline Other (ref.: White) & $\begin{array}{l}0.866 \\
(1.172)\end{array}$ \\
\hline Female & $\begin{array}{l}-0.280^{* * *} \\
(0.062)\end{array}$ \\
\hline Foreign Born & $\begin{array}{l}-0.005 \\
(0.210)\end{array}$ \\
\hline Mother in Home & $\begin{array}{l}0.238^{*} \\
(0.142)\end{array}$ \\
\hline Father in Home & $\begin{array}{l}-0.050 \\
(0.086)\end{array}$ \\
\hline Self-Esteem & $\begin{array}{l}0.088 * * * \\
(0.033)\end{array}$ \\
\hline Locus of Control & $\begin{array}{l}0.455^{* * *} * \\
(0.037)\end{array}$ \\
\hline Effort & $\begin{array}{l}0.471 * * * \\
(0.041)\end{array}$ \\
\hline Constant & $\begin{array}{l}-4.465^{* * *} \\
(0.288)\end{array}$ \\
\hline Observations & 9,636 \\
\hline
\end{tabular}


Table S.9. Logistic response model of college attainment estimated with demographic covariates and the main analytic data set.

\begin{tabular}{|c|c|}
\hline 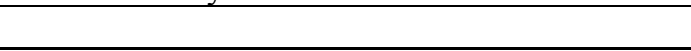 & College Attainment \\
\hline Family Income & $\begin{array}{l}0.000 \\
(0.004)\end{array}$ \\
\hline Parental Education & $\begin{array}{l}0.133 * * * \\
(0.023)\end{array}$ \\
\hline Parental SEI & $\begin{array}{l}0.001 \\
(0.002)\end{array}$ \\
\hline Sibship Size & $\begin{array}{l}-0.017 \\
(0.026)\end{array}$ \\
\hline Hispanic or Spanish (ref.: White) & $\begin{array}{l}-0.438 * * * \\
(0.151)\end{array}$ \\
\hline American Indian or Alaskan Native (ref.: White) & $\begin{array}{l}-0.772 * * \\
(0.336)\end{array}$ \\
\hline Asian or Pacific Islander (ref.: White) & $\begin{array}{l}0.281 \\
(0.237)\end{array}$ \\
\hline Black (ref.: White) & $\begin{array}{l}-0.582 * * * \\
(0.157)\end{array}$ \\
\hline Other (ref.: White) & $\begin{array}{l}-1.072 \\
(1.219)\end{array}$ \\
\hline Female & $\begin{array}{l}0.002 \\
(0.089)\end{array}$ \\
\hline Foreign Born & $\begin{array}{l}0.208 \\
(0.236)\end{array}$ \\
\hline Mother in Home & $\begin{array}{l}0.219 \\
(0.178)\end{array}$ \\
\hline Father in Home & $\begin{array}{l}0.466^{* * *} \\
(0.117)\end{array}$ \\
\hline Constant & $\begin{array}{l}-1.776^{* * *} \\
(0.346)\end{array}$ \\
\hline Observations & 4,562 \\
\hline
\end{tabular}


Table S.10. Logistic response model of college attainment estimated with demographic and cognitive covariates and the main analytic data set.

\begin{tabular}{|c|c|}
\hline & College Attainment \\
\hline Family Income & $\begin{array}{l}0.001 \\
(0.004)\end{array}$ \\
\hline Parental Education & $\begin{array}{l}0.109 * * * \\
(0.024)\end{array}$ \\
\hline Parental SEI & $\begin{array}{l}-0.002 \\
(0.003)\end{array}$ \\
\hline Sibship Size & $\begin{array}{l}-0.012 \\
(0.027)\end{array}$ \\
\hline Hispanic or Spanish (ref.: White) & $\begin{array}{l}-0.174 \\
(0.160)\end{array}$ \\
\hline American Indian or Alaskan Native (ref.: White) & $\begin{array}{l}-0.584 \\
(0.372)\end{array}$ \\
\hline Asian or Pacific Islander (ref.: White) & $\begin{array}{l}0.009 \\
(0.245)\end{array}$ \\
\hline Black (ref.: White) & $\begin{array}{l}-0.240 \\
(0.172)\end{array}$ \\
\hline Other (ref.: White) & $\begin{array}{l}-0.022 \\
(1.058)\end{array}$ \\
\hline Female & $\begin{array}{l}-0.142 \\
(0.100)\end{array}$ \\
\hline Foreign Born & $\begin{array}{l}0.167 \\
(0.226)\end{array}$ \\
\hline Mother in Home & $\begin{array}{l}0.066 \\
(0.197)\end{array}$ \\
\hline Father in Home & $\begin{array}{l}0.317^{* * * *} \\
(0.120)\end{array}$ \\
\hline Vocabulary & $\begin{array}{l}0.037 \\
(0.078)\end{array}$ \\
\hline Reading & $\begin{array}{l}-0.060 \\
(0.077)\end{array}$ \\
\hline Math & $\begin{array}{l}0.024 \\
(0.073)\end{array}$ \\
\hline Science & $\begin{array}{l}-0.089 \\
(0.076)\end{array}$ \\
\hline Writing & $\begin{array}{l}-0.017 \\
(0.086)\end{array}$ \\
\hline Civics & $\begin{array}{l}0.203 * * * \\
(0.064)\end{array}$ \\
\hline High School GPA & $\begin{array}{l}0.779 * * * \\
(0.099)\end{array}$ \\
\hline Highest Math Course & $\begin{array}{l}0.264 * * * \\
(0.045)\end{array}$ \\
\hline Constant & $\begin{array}{l}-4.472 * * * \\
(0.478)\end{array}$ \\
\hline Observations & 4,562 \\
\hline
\end{tabular}


Table S.11. Logistic response model of college attainment estimated with demographic, cognitive, and noncognitive covariates and the main analytic data set.

\begin{tabular}{|c|c|}
\hline & College Attainment \\
\hline Family Income & $\begin{array}{l}0.002 \\
(0.004)\end{array}$ \\
\hline Parental Education & $\begin{array}{l}0.114 * * * \\
(0.024)\end{array}$ \\
\hline Parental SEI & $\begin{array}{l}-0.002 \\
(0.003)\end{array}$ \\
\hline Sibship Size & $\begin{array}{l}-0.005 \\
(0.027)\end{array}$ \\
\hline Hispanic or Spanish (ref.: White) & $\begin{array}{l}-0.138 \\
(0.161)\end{array}$ \\
\hline American Indian or Alaskan Native (ref.: White) & $\begin{array}{l}-0.566 \\
(0.361)\end{array}$ \\
\hline Asian or Pacific Islander (ref.: White) & $\begin{array}{l}0.035 \\
(0.251)\end{array}$ \\
\hline Black (ref.: White) & $\begin{array}{l}-0.266 \\
(0.171)\end{array}$ \\
\hline Other (ref.: White) & $\begin{array}{l}0.072 \\
(1.044)\end{array}$ \\
\hline Female & $\begin{array}{l}-0.178 * \\
(0.101)\end{array}$ \\
\hline Foreign Born & $\begin{array}{l}0.169 \\
(0.227)\end{array}$ \\
\hline Mother in Home & $\begin{array}{l}0.032 \\
(0.196)\end{array}$ \\
\hline Father in Home & $\begin{array}{l}0.281 * * \\
(0.120)\end{array}$ \\
\hline Vocabulary & $\begin{array}{l}0.033 \\
(0.078)\end{array}$ \\
\hline Reading & $\begin{array}{l}-0.048 \\
(0.078)\end{array}$ \\
\hline Math & $\begin{array}{l}0.035 \\
(0.073)\end{array}$ \\
\hline Science & $\begin{array}{l}-0.092 \\
(0.077)\end{array}$ \\
\hline Writing & $\begin{array}{l}-0.021 \\
(0.085)\end{array}$ \\
\hline Civics & $\begin{array}{l}0.201 * * * \\
(0.064)\end{array}$ \\
\hline High School GPA & $\begin{array}{l}0.680 * * * \\
(0.103)\end{array}$ \\
\hline Highest Math Course & $\begin{array}{l}0.242 * * * \\
(0.046)\end{array}$ \\
\hline Self-Esteem & $\begin{array}{l}-0.010 \\
(0.049)\end{array}$ \\
\hline Locus of Control & $\begin{array}{l}0.048 \\
(0.057)\end{array}$ \\
\hline Effort & $\begin{array}{l}0.234 * * * \\
(0.056)\end{array}$ \\
\hline Constant & $\begin{array}{l}-4.207 * * * \\
(0.482)\end{array}$ \\
\hline Observations & 4,562 \\
\hline
\end{tabular}


Table S.12. Logistic response model of college attainment estimated with demographic and noncognitive covariates and the main analytic data set.

\begin{tabular}{|c|c|c|c|}
\hline & & & College Attainment \\
\hline & & Family Income & $\begin{array}{l}0.002 \\
(0.004)\end{array}$ \\
\hline & & Parental Education & $\begin{array}{l}0.137^{* * * *} \\
(0.023)\end{array}$ \\
\hline & & Parental SEI & $\begin{array}{l}-0.000 \\
(0.002)\end{array}$ \\
\hline & & Sibship Size & $\begin{array}{l}-0.001 \\
(0.026)\end{array}$ \\
\hline & & Hispanic or Spanish (ref.: White) & $\begin{array}{l}-0.319 * * \\
(0.156)\end{array}$ \\
\hline & & American Indian or Alaskan Native (ref.: White) & $\begin{array}{l}-0.697^{* *} \\
(0.325)\end{array}$ \\
\hline & & Asian or Pacific Islander (ref.: White) & $\begin{array}{l}0.289 \\
(0.249)\end{array}$ \\
\hline & & Black (ref.: White) & $\begin{array}{l}-0.580 * * * \\
(0.157)\end{array}$ \\
\hline & & Other (ref.: White) & $\begin{array}{l}-0.561 \\
(1.014)\end{array}$ \\
\hline & & Female & $\begin{array}{l}-0.106 \\
(0.091)\end{array}$ \\
\hline & & Foreign Born & $\begin{array}{l}0.201 \\
(0.242)\end{array}$ \\
\hline & & Mother in Home & $\begin{array}{l}0.138 \\
(0.177)\end{array}$ \\
\hline & & Father in Home & $\begin{array}{l}0.360 * * * \\
(0.117)\end{array}$ \\
\hline & & Self-Esteem & $\begin{array}{l}0.006 \\
(0.047)\end{array}$ \\
\hline & & Locus of Control & $\begin{array}{l}0.181 * * * \\
(0.051)\end{array}$ \\
\hline & & Effort & $\begin{array}{l}0.427 * * * \\
(0.052)\end{array}$ \\
\hline & & Constant & $\begin{array}{l}-1.858 * * * \\
(0.340)\end{array}$ \\
\hline & & Observations & 4,562 \\
\hline
\end{tabular}


Table S.13. Logistic response model of grad school entry estimated with demographic covariates and the main analytic data set.

\begin{tabular}{ll}
\hline & Grad School Entry \\
\hline Family Income & 0.004 \\
Parental Education & $(0.005)$ \\
& $0.069^{* *}$ \\
Parental SEI & $(0.030)$ \\
& $0.008^{* *}$ \\
Sibship Size & $(0.003)$ \\
& 0.031 \\
Hispanic or Spanish (ref.: White) & $(0.038)$ \\
& -0.014 \\
American Indian or Alaskan Native (ref.: White) & $(0.223)$ \\
& -0.395 \\
Asian or Pacific Islander (ref.: White) & $(0.625)$ \\
& $0.717^{* * *}$ \\
Black (ref.: White) & $(0.273)$ \\
& 0.038 \\
Other (ref.: White) & $(0.212)$ \\
& - \\
Female & -0.085 \\
Foreign Born & $(0.106)$ \\
Mother in Home & 0.274 \\
Father in Home & $(0.254)$ \\
Constant & 0.090 \\
& $(0.286)$ \\
Observations & 0.083 \\
& $(0.156)$ \\
& $-2.812^{* * *}$ \\
& $(0.496)$ \\
& 2,894 \\
\hline & Robust standard errors in parentheses \\
&
\end{tabular}


Table S.14. Logistic response model of grad school entry estimated with demographic and cognitive covariates and the main analytic data set.

\begin{tabular}{|c|c|}
\hline & Grad School Entry \\
\hline Family Income & $\begin{array}{l}0.003 \\
(0.005)\end{array}$ \\
\hline Parental Education & $\begin{array}{l}0.051 \\
(0.031)\end{array}$ \\
\hline Parental SEI & $\begin{array}{l}0.007 * * \\
(0.003)\end{array}$ \\
\hline Sibship Size & $\begin{array}{l}0.037 \\
(0.040)\end{array}$ \\
\hline Hispanic or Spanish (ref.: White) & $\begin{array}{l}0.216 \\
(0.238)\end{array}$ \\
\hline American Indian or Alaskan Native (ref.: White) & $\begin{array}{l}-0.158 \\
(0.635)\end{array}$ \\
\hline Asian or Pacific Islander (ref.: White) & $\begin{array}{l}0.701 * * \\
(0.282)\end{array}$ \\
\hline Black (ref.: White) & $\begin{array}{l}0.391^{*} \\
(0.226)\end{array}$ \\
\hline Other (ref.: White) & - \\
\hline Female & $\begin{array}{l}-0.011 \\
(0.124)\end{array}$ \\
\hline Foreign Born & $\begin{array}{l}0.230 \\
(0.255)\end{array}$ \\
\hline Mother in Home & $\begin{array}{l}0.038 \\
(0.294)\end{array}$ \\
\hline Father in Home & $\begin{array}{l}0.025 \\
(0.161)\end{array}$ \\
\hline Vocabulary & $\begin{array}{l}0.023 \\
(0.101)\end{array}$ \\
\hline Reading & $\begin{array}{l}0.071 \\
(0.098)\end{array}$ \\
\hline Math & $\begin{array}{l}0.186^{*} \\
(0.097)\end{array}$ \\
\hline Science & $\begin{array}{l}0.103 \\
(0.099)\end{array}$ \\
\hline Writing & $\begin{array}{l}-0.140 \\
(0.114)\end{array}$ \\
\hline Civics & $\begin{array}{l}0.094 \\
(0.088)\end{array}$ \\
\hline High School GPA & $\begin{array}{l}0.308^{* *} \\
(0.140)\end{array}$ \\
\hline Highest Math Course & $\begin{array}{l}0.085 \\
(0.064)\end{array}$ \\
\hline Constant & $\begin{array}{l}-4.109 * * * \\
(0.676)\end{array}$ \\
\hline Observations & 2,894 \\
\hline
\end{tabular}


Table S.15. Logistic response model of grad school entry estimated with demographic, cognitive, and noncognitive covariates and the main analytic data set.

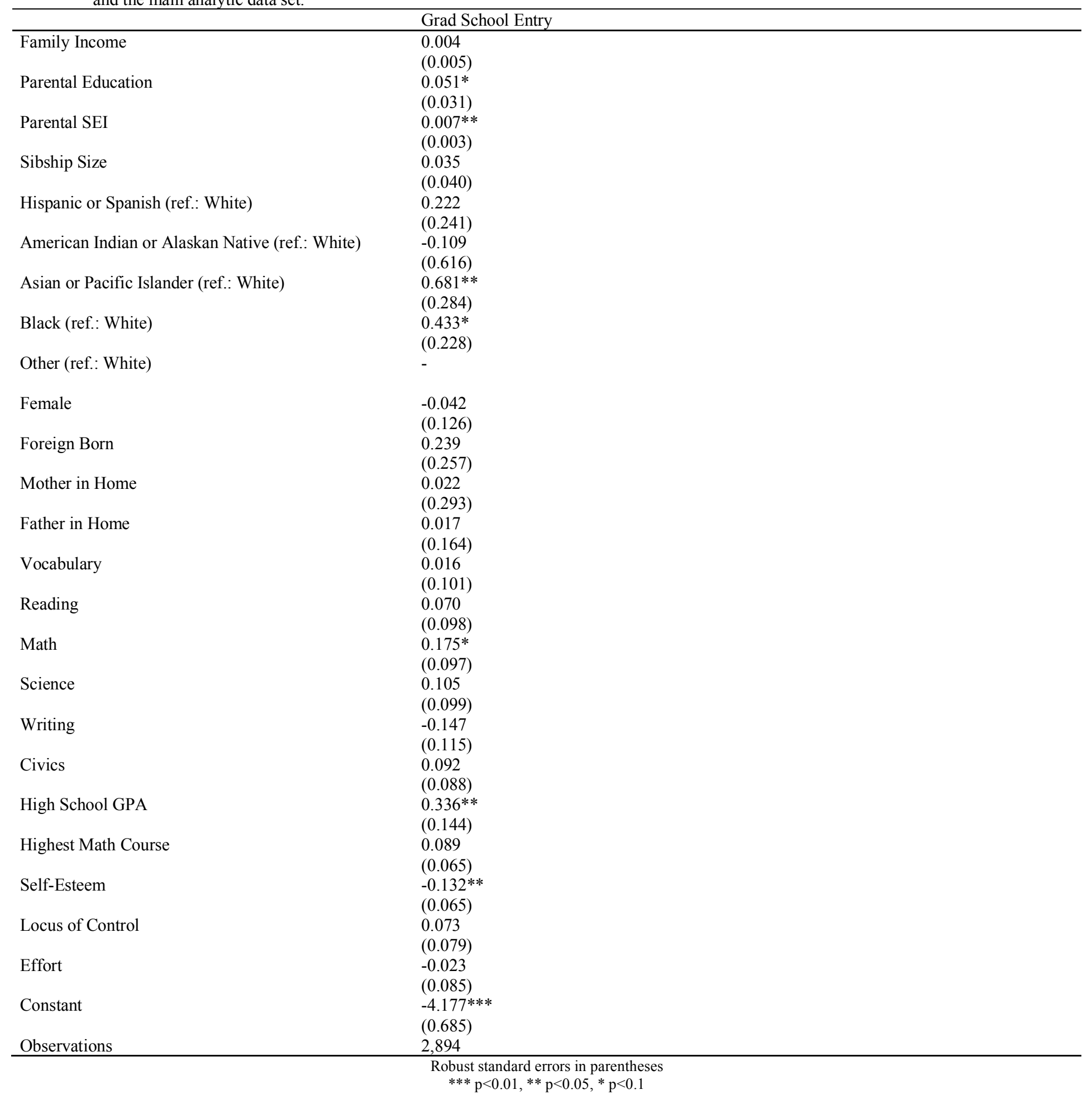


Table S.16. Logistic response model of grad school entry estimated with demographic and noncognitive covariates and the main analytic data set.

\begin{tabular}{|c|c|c|c|}
\hline & & & Grad School Entry \\
\hline & & Family Income & $\begin{array}{l}0.004 \\
(0.005)\end{array}$ \\
\hline & & Parental Education & $\begin{array}{l}0.067 * * \\
(0.030)\end{array}$ \\
\hline & & Parental SEI & $\begin{array}{l}0.008 * * \\
(0.003)\end{array}$ \\
\hline & & Sibship Size & $\begin{array}{l}0.033 \\
(0.038)\end{array}$ \\
\hline & & Hispanic or Spanish (ref.: White) & $\begin{array}{l}0.035 \\
(0.226)\end{array}$ \\
\hline & & American Indian or Alaskan Native (ref.: White) & $\begin{array}{l}-0.320 \\
(0.606)\end{array}$ \\
\hline & & Asian or Pacific Islander (ref.: White) & $\begin{array}{l}0.710^{* *} \\
(0.276)\end{array}$ \\
\hline & & Black (ref.: White) & $\begin{array}{l}0.091 \\
(0.213)\end{array}$ \\
\hline & & Other (ref.: White) & - \\
\hline & & Female & $\begin{array}{l}-0.148 \\
(0.109)\end{array}$ \\
\hline & & Foreign Born & $\begin{array}{l}0.285 \\
(0.258)\end{array}$ \\
\hline & & Mother in Home & $\begin{array}{l}0.067 \\
(0.284)\end{array}$ \\
\hline & & Father in Home & $\begin{array}{l}0.062 \\
(0.158)\end{array}$ \\
\hline & & Self-Esteem & $\begin{array}{l}-0.122 * \\
(0.064)\end{array}$ \\
\hline & & Locus of Control & $\begin{array}{l}0.192 * * \\
(0.076)\end{array}$ \\
\hline & & Effort & $\begin{array}{l}0.072 \\
(0.082)\end{array}$ \\
\hline & & Constant & $\begin{array}{l}-2.835 * * * \\
(0.491)\end{array}$ \\
\hline & & Observations & 2,894 \\
\hline
\end{tabular}


Table S.17. Logistic response model of grad school attainment estimated with demographic covariates and the main analytic data set.

\begin{tabular}{|c|c|}
\hline & Grad School Attainment \\
\hline Family Income & $\begin{array}{l}0.011 \\
(0.008)\end{array}$ \\
\hline Parental Education & $\begin{array}{l}0.125 * * \\
(0.051)\end{array}$ \\
\hline Parental SEI & $\begin{array}{l}-0.003 \\
(0.005)\end{array}$ \\
\hline Sibship Size & $\begin{array}{l}-0.119 * \\
(0.064)\end{array}$ \\
\hline Hispanic or Spanish (ref.: White) & $\begin{array}{l}-0.689^{* *} \\
(0.331)\end{array}$ \\
\hline American Indian or Alaskan Native (ref.: White) & $\begin{array}{l}-0.373 \\
(0.957)\end{array}$ \\
\hline Asian or Pacific Islander (ref.: White) & $\begin{array}{l}-0.113 \\
(0.440)\end{array}$ \\
\hline Black (ref.: White) & $\begin{array}{l}0.027 \\
(0.368)\end{array}$ \\
\hline Foreign Born & $\begin{array}{l}0.196 \\
(0.413)\end{array}$ \\
\hline Mother in Home & $\begin{array}{l}-0.598 \\
(0.419)\end{array}$ \\
\hline Father in Home & $\begin{array}{l}-0.175 \\
(0.277)\end{array}$ \\
\hline Constant & $\begin{array}{l}-0.836 \\
(0.803)\end{array}$ \\
\hline Observations & 841 \\
\hline
\end{tabular}


Table S.18. Logistic response model of grad school attainment estimated with demographic and cognitive covariates and the main analytic data set.

\begin{tabular}{|c|c|}
\hline$\rightarrow$ & Grad School Attainment \\
\hline Family Income & $\begin{array}{l}0.013 \\
(0.009)\end{array}$ \\
\hline Parental Education & $\begin{array}{l}0.128 * * \\
(0.053)\end{array}$ \\
\hline Parental SEI & $\begin{array}{l}-0.004 \\
(0.006)\end{array}$ \\
\hline Sibship Size & $\begin{array}{l}-0.133 * * \\
(0.065)\end{array}$ \\
\hline Hispanic or Spanish (ref.: White) & $\begin{array}{l}-0.545 \\
(0.370)\end{array}$ \\
\hline American Indian or Alaskan Native (ref.: White) & $\begin{array}{l}-0.163 \\
(0.998)\end{array}$ \\
\hline Asian or Pacific Islander (ref.: White) & $\begin{array}{l}-0.232 \\
(0.443)\end{array}$ \\
\hline Black (ref.: White) & $\begin{array}{l}0.213 \\
(0.409)\end{array}$ \\
\hline Female & $\begin{array}{l}-0.107 \\
(0.209)\end{array}$ \\
\hline Foreign Born & $\begin{array}{l}0.253 \\
(0.436)\end{array}$ \\
\hline Mother in Home & $\begin{array}{l}-0.522 \\
(0.450)\end{array}$ \\
\hline Father in Home & $\begin{array}{l}-0.251 \\
(0.290)\end{array}$ \\
\hline Vocabulary & $\begin{array}{l}0.017 \\
(0.190)\end{array}$ \\
\hline Reading & $\begin{array}{l}-0.327^{* *} \\
(0.166)\end{array}$ \\
\hline Math & $\begin{array}{l}-0.034 \\
(0.160)\end{array}$ \\
\hline Science & $\begin{array}{l}0.151 \\
(0.168)\end{array}$ \\
\hline Writing & $\begin{array}{l}0.070 \\
(0.196)\end{array}$ \\
\hline Civics & $\begin{array}{l}0.143 \\
(0.143)\end{array}$ \\
\hline High School GPA & $\begin{array}{l}0.753 * * * \\
(0.219)\end{array}$ \\
\hline Highest Math Course & $\begin{array}{l}-0.067 \\
(0.112)\end{array}$ \\
\hline Constant & $\begin{array}{l}-2.856^{* *} \\
(1.119)\end{array}$ \\
\hline Observations & 841 \\
\hline
\end{tabular}


Table S.19. Logistic response model of grad school attainment estimated with demographic, cognitive, and noncognitive covariates and the main analytic data set.

\begin{tabular}{|c|c|}
\hline & Grad School Attainment \\
\hline Family Income & $\begin{array}{l}0.014 \\
(0.009)\end{array}$ \\
\hline Parental Education & $\begin{array}{l}0.126^{* *} \\
(0.054)\end{array}$ \\
\hline Parental SEI & $\begin{array}{l}-0.003 \\
(0.006)\end{array}$ \\
\hline Sibship Size & $\begin{array}{l}-0.130 * * \\
(0.066)\end{array}$ \\
\hline Hispanic or Spanish (ref.: White) & $\begin{array}{l}-0.559 \\
(0.372)\end{array}$ \\
\hline American Indian or Alaskan Native (ref.: White) & $\begin{array}{l}-0.254 \\
(1.026)\end{array}$ \\
\hline Asian or Pacific Islander (ref.: White) & $\begin{array}{l}-0.255 \\
(0.435)\end{array}$ \\
\hline Black (ref.: White) & $\begin{array}{l}0.209 \\
(0.421)\end{array}$ \\
\hline Foreign Born & $\begin{array}{l}0.258 \\
(0.422)\end{array}$ \\
\hline Mother in Home & $\begin{array}{l}-0.563 \\
(0.465)\end{array}$ \\
\hline Father in Home & $\begin{array}{l}-0.234 \\
(0.293)\end{array}$ \\
\hline Vocabulary & $\begin{array}{l}0.035 \\
(0.195)\end{array}$ \\
\hline Reading & $\begin{array}{l}-0.308 * \\
(0.170)\end{array}$ \\
\hline Math & $\begin{array}{l}0.016 \\
(0.163)\end{array}$ \\
\hline Science & $\begin{array}{l}0.151 \\
(0.170)\end{array}$ \\
\hline Writing & $\begin{array}{l}0.095 \\
(0.200)\end{array}$ \\
\hline High School GPA & $\begin{array}{l}0.673^{* * *} \\
(0.228)\end{array}$ \\
\hline Highest Math Course & $\begin{array}{l}-0.100 \\
(0.119)\end{array}$ \\
\hline Self-Esteem & $\begin{array}{l}0.101 \\
(0.109)\end{array}$ \\
\hline Locus of Control & $\begin{array}{l}-0.194 \\
(0.134)\end{array}$ \\
\hline Effort & $\begin{array}{l}0.198 \\
(0.125)\end{array}$ \\
\hline Constant & $\begin{array}{l}-2.573 * * \\
(1.132)\end{array}$ \\
\hline Observations & 841 \\
\hline
\end{tabular}


Table S.20. Logistic response model of grad school attainment estimated with demographic and noncognitive covariates and the main analytic data set.

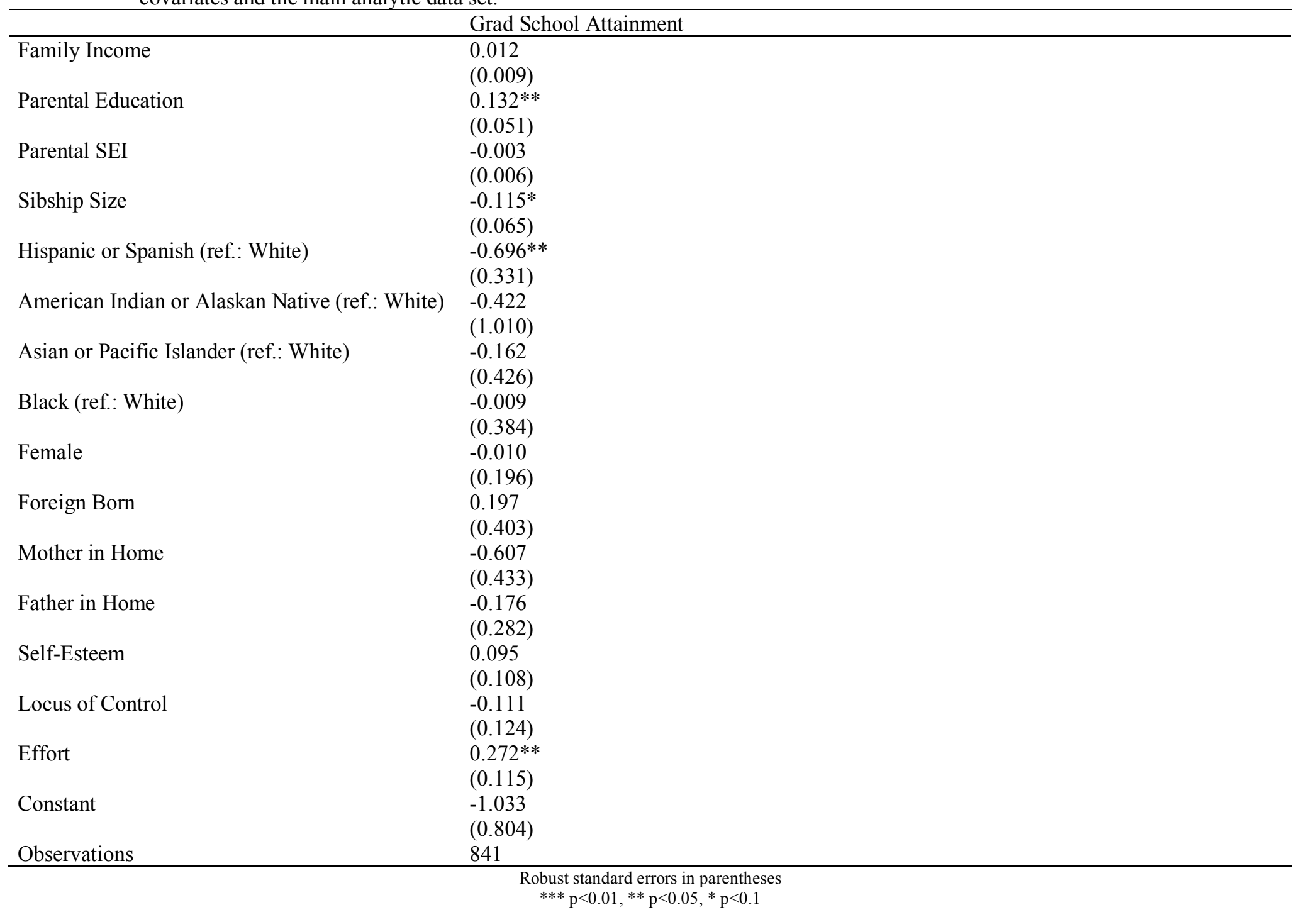


Table S.21. Logistic response model of alternately defined college entry, estimated with demographic covariates and the main analytic data set. College entry is defined as entry into either a baccalaureate college or a two-year college.

\begin{tabular}{|c|c|}
\hline & College Entry (2yr or $4 y r)$ \\
\hline Family Income & $\begin{array}{l}0.014 * * * \\
(0.003)\end{array}$ \\
\hline Parental Education & $\begin{array}{l}0.240 * * * \\
(0.016)\end{array}$ \\
\hline Parental SEI & $\begin{array}{l}0.008 * * * \\
(0.002)\end{array}$ \\
\hline Sibship Size & $\begin{array}{l}-0.083 * * * \\
(0.019)\end{array}$ \\
\hline Hispanic or Spanish (ref.: White) & $\begin{array}{l}-0.435 * * * \\
(0.087)\end{array}$ \\
\hline American Indian or Alaskan Native (ref.: White) & $\begin{array}{l}-0.406^{*} \\
(0.221)\end{array}$ \\
\hline Asian or Pacific Islander (ref.: White) & $\begin{array}{l}0.435 * * \\
(0.213)\end{array}$ \\
\hline Black (ref.: White) & $\begin{array}{l}-0.052 \\
(0.102)\end{array}$ \\
\hline Other (ref.: White) & $\begin{array}{l}0.219 \\
(0.748)\end{array}$ \\
\hline Female & $\begin{array}{l}0.143 * * \\
(0.057)\end{array}$ \\
\hline Foreign Born & $\begin{array}{l}0.302 * \\
(0.175)\end{array}$ \\
\hline Mother in Home & $\begin{array}{l}0.267 * * \\
(0.125)\end{array}$ \\
\hline Father in Home & $\begin{array}{l}0.097 \\
(0.076)\end{array}$ \\
\hline Constant & $\begin{array}{l}-3.427 * * * \\
(0.246)\end{array}$ \\
\hline Observations & 9,636 \\
\hline
\end{tabular}


Table S.22. Logistic response model of alternately defined college entry, estimated with demographic and cognitive covariates and the main analytic data set. College entry is defined as entry into either a baccalaureate college or a two-year college.

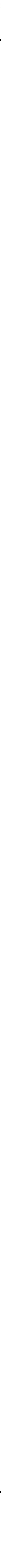


Table S.23. Logistic response model of alternately defined college entry, estimated with demographic, cognitive, and noncognitive covariates and the main analytic data set. College entry is defined as entry into either a baccalaureate college or a two-year college.

\begin{tabular}{|c|c|}
\hline & College Entry (2yr or 4yr) \\
\hline Family Income & $\begin{array}{l}0.013 * * * \\
(0.003)\end{array}$ \\
\hline Parental Education & $\begin{array}{l}0.152 * * * \\
(0.017)\end{array}$ \\
\hline Parental SEI & $\begin{array}{l}0.004 * * \\
(0.002)\end{array}$ \\
\hline Sibship Size & $\begin{array}{l}-0.043^{*} \\
(0.022)\end{array}$ \\
\hline Hispanic or Spanish (ref.: White) & $\begin{array}{l}0.114 \\
(0.098)\end{array}$ \\
\hline American Indian or Alaskan Native (ref.: White) & $\begin{array}{l}-0.025 \\
(0.262)\end{array}$ \\
\hline Asian or Pacific Islander (ref.: White) & $\begin{array}{l}0.232 \\
(0.212)\end{array}$ \\
\hline Black (ref.: White) & $\begin{array}{l}0.461 * * * \\
(0.118)\end{array}$ \\
\hline Other (ref.: White) & $\begin{array}{l}0.917 \\
(1.236)\end{array}$ \\
\hline Female & $\begin{array}{l}0.044 \\
(0.078)\end{array}$ \\
\hline Foreign Born & $\begin{array}{l}0.301^{*} \\
(0.183)\end{array}$ \\
\hline Mother in Home & $\begin{array}{l}0.075 \\
(0.150)\end{array}$ \\
\hline Father in Home & $\begin{array}{l}-0.091 \\
(0.086)\end{array}$ \\
\hline Vocabulary & $\begin{array}{l}0.140 * * \\
(0.055)\end{array}$ \\
\hline Reading & $\begin{array}{l}0.188 * * * \\
(0.054)\end{array}$ \\
\hline Math & $\begin{array}{l}0.047 \\
(0.058)\end{array}$ \\
\hline Science & $\begin{array}{l}0.059 \\
(0.055)\end{array}$ \\
\hline Writing & $\begin{array}{l}-0.051 \\
(0.058)\end{array}$ \\
\hline Civics & $\begin{array}{l}0.099 * * \\
(0.046)\end{array}$ \\
\hline High School GPA & $\begin{array}{l}0.595 * * * \\
(0.074)\end{array}$ \\
\hline Highest Math Course & $\begin{array}{l}0.384 * * * \\
(0.028)\end{array}$ \\
\hline Self-Esteem & $\begin{array}{l}0.061^{*} \\
(0.034)\end{array}$ \\
\hline Locus of Control & $\begin{array}{l}0.090 * * \\
(0.039)\end{array}$ \\
\hline Effort & $\begin{array}{l}0.134 * * * \\
(0.041)\end{array}$ \\
\hline Constant & $\begin{array}{l}-4.777 * * * \\
(0.338)\end{array}$ \\
\hline Observations & 9,636 \\
\hline
\end{tabular}


Table S.24. Logistic response model of college attainment given alternate college entry definition, estimated with demographic covariates and the main analytic data set. College entry is defined as entry into either a baccalaureate college or a two-year college.

College Attainment

\begin{tabular}{|c|c|}
\hline Family Income & $\begin{array}{l}0.008 * * \\
(0.003)\end{array}$ \\
\hline Parental Education & $\begin{array}{l}0.213 * * * \\
(0.020)\end{array}$ \\
\hline Parental SEI & $\begin{array}{l}0.002 \\
(0.002)\end{array}$ \\
\hline Sibship Size & $\begin{array}{l}-0.039 * \\
(0.023)\end{array}$ \\
\hline Hispanic or Spanish (ref.: White) & $\begin{array}{l}-0.360^{* * *} \\
(0.131)\end{array}$ \\
\hline American Indian or Alaskan Native (ref.: White) & $\begin{array}{l}-0.793 * * * \\
(0.299)\end{array}$ \\
\hline Asian or Pacific Islander (ref.: White) & $\begin{array}{l}0.584 * * * \\
(0.218)\end{array}$ \\
\hline Black (ref.: White) & $\begin{array}{l}-0.429 * * * \\
(0.132)\end{array}$ \\
\hline Other (ref.: White) & $\begin{array}{l}-0.964 \\
(0.990)\end{array}$ \\
\hline Female & $\begin{array}{l}-0.145^{*} \\
(0.074)\end{array}$ \\
\hline Foreign Born & $\begin{array}{l}-0.009 \\
(0.209)\end{array}$ \\
\hline Mother in Home & $\begin{array}{l}0.235 \\
(0.156)\end{array}$ \\
\hline Father in Home & $\begin{array}{l}0.345^{* * *} \\
(0.103)\end{array}$ \\
\hline Constant & $\begin{array}{l}-3.529 * * * \\
(0.304)\end{array}$ \\
\hline Observations & 5,996 \\
\hline
\end{tabular}


Table S.25. Logistic response model of college attainment given alternate college entry definition, estimated with demographic and cognitive covariates and the main analytic data set. College entry is defined as entry into either a baccalaureate college or a two-year college.

\begin{tabular}{|c|c|}
\hline & College Attainment \\
\hline Family Income & $\begin{array}{l}0.008^{* *} \\
(0.004)\end{array}$ \\
\hline Parental Education & $\begin{array}{l}0.166 * * * \\
(0.022)\end{array}$ \\
\hline Parental SEI & $\begin{array}{l}-0.002 \\
(0.002)\end{array}$ \\
\hline Sibship Size & $\begin{array}{l}-0.019 \\
(0.025)\end{array}$ \\
\hline Hispanic or Spanish (ref.: White) & $\begin{array}{l}0.045 \\
(0.149)\end{array}$ \\
\hline American Indian or Alaskan Native (ref.: White) & $\begin{array}{l}-0.455 \\
(0.322)\end{array}$ \\
\hline Asian or Pacific Islander (ref.: White) & $\begin{array}{l}0.307 \\
(0.230)\end{array}$ \\
\hline Black (ref.: White) & $\begin{array}{l}0.075 \\
(0.156)\end{array}$ \\
\hline Other (ref.: White) & $\begin{array}{l}0.031 \\
(1.010)\end{array}$ \\
\hline Female & $\begin{array}{l}-0.253^{* * *} \\
(0.089)\end{array}$ \\
\hline Foreign Born & $\begin{array}{l}-0.093 \\
(0.233)\end{array}$ \\
\hline Mother in Home & $\begin{array}{l}0.020 \\
(0.179)\end{array}$ \\
\hline Father in Home & $\begin{array}{l}0.187 * \\
(0.110)\end{array}$ \\
\hline Vocabulary & $\begin{array}{l}0.105 \\
(0.070)\end{array}$ \\
\hline Reading & $\begin{array}{l}-0.062 \\
(0.072)\end{array}$ \\
\hline Math & $\begin{array}{l}0.039 \\
(0.067)\end{array}$ \\
\hline Science & $\begin{array}{l}-0.048 \\
(0.068)\end{array}$ \\
\hline Writing & $\begin{array}{l}0.010 \\
(0.077)\end{array}$ \\
\hline Civics & $\begin{array}{l}0.222 * * * \\
(0.056)\end{array}$ \\
\hline High School GPA & $\begin{array}{l}0.875^{* * *} \\
(0.089)\end{array}$ \\
\hline Highest Math Course & $\begin{array}{l}0.391 * * * \\
(0.040)\end{array}$ \\
\hline Constant & $\begin{array}{l}-6.651^{* * *} \\
(0.436)\end{array}$ \\
\hline Observations & 5,996 \\
\hline
\end{tabular}


Table S.26. Logistic response model of college attainment given alternate college entry definition, estimated with demographic, cognitive, and noncognitive covariates and the main analytic data set. College entry is defined as entry into either a baccalaureate college or a two-year college.

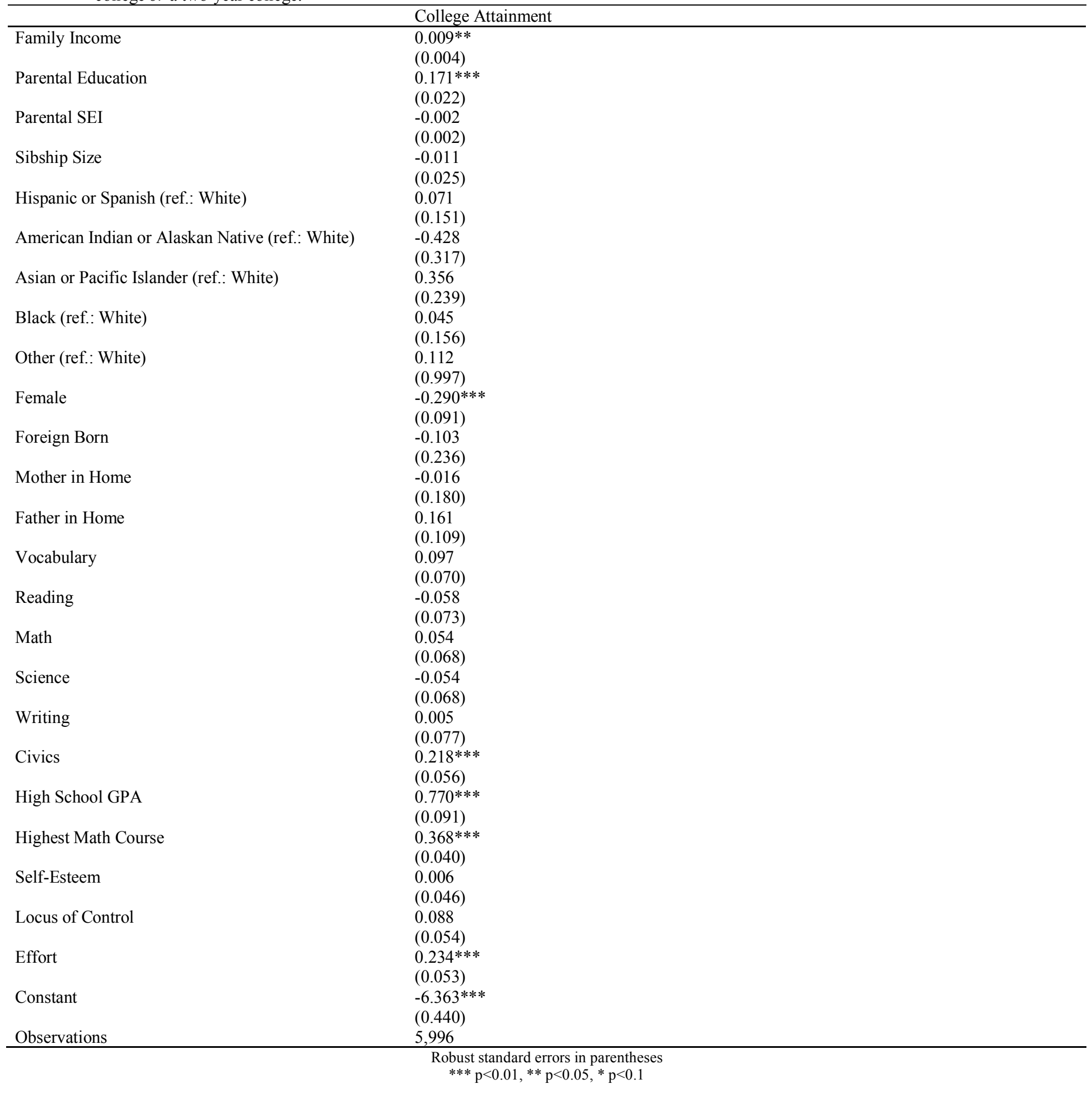


Table S.27. Logistic response model of high school attainment estimated with demographic covariates and the smaller sample of respondents who completed the long-form 2014 questionnaire.

\begin{tabular}{ll}
\hline & High School Attainment \\
\hline Family Income & -0.000 \\
& $(0.010)$ \\
Parental Education & $0.241^{* * *}$ \\
& $(0.043)$ \\
Parental SEI & 0.002 \\
& $(0.006)$ \\
Sibship Size & $-0.172^{* * *}$ \\
& $(0.051)$ \\
Hispanic or Spanish (ref.: White) & -0.154 \\
& $(0.229)$ \\
American Indian or Alaskan Native (ref.: White) & - \\
& \\
Asian or Pacific Islander (ref.: White) & 0.948 \\
& $(1.029)$ \\
Black (ref.: White) & -0.186 \\
Other (ref.: White) & $(0.260)$ \\
& -0.705 \\
Female & $(1.151)$ \\
Foreign Born & $0.340^{* *}$ \\
& $(0.168)$ \\
Mother in Home & 0.596 \\
Father in Home & $(0.544)$ \\
Constant & $0.711^{* * *}$ \\
Observations & $(0.246)$ \\
& $0.491^{* *}$ \\
& $(0.204)$ \\
& -0.626 \\
& $(0.533)$ \\
& 3,369 \\
\hline & Robust standard errors in parentheses \\
& \\
&
\end{tabular}

Robust standard errors in parenthese

$* * * \mathrm{p}<0.01, * * \mathrm{p}<0.05, * \mathrm{p}<0.1$ 
Table S.28. Logistic response model of high school attainment estimated with demographic and cognitive covariates and the smaller sample of respondents who completed the long-form 2014 questionnaire.

\begin{tabular}{|c|c|}
\hline & High School Attainment \\
\hline Family Income & $\begin{array}{l}-0.006 \\
(0.010)\end{array}$ \\
\hline Parental Education & $0.104^{* *}$ \\
\hline Parental SEI & $\begin{array}{l}(0.048) \\
-0.005 \\
(0.006)\end{array}$ \\
\hline Sibship Size & $\begin{array}{l}-0.119 * * \\
(0.056)\end{array}$ \\
\hline Hispanic or Spanish (ref.: White) & $\begin{array}{l}0.489 * * \\
(0.243)\end{array}$ \\
\hline American Indian or Alaskan Native (ref:: White) & - \\
\hline Asian or Pacific Islander (ref.: White) & $\begin{array}{l}0.612 \\
(1.103)\end{array}$ \\
\hline Black (ref.: White) & $\begin{array}{l}0.514^{*} \\
(0.303)\end{array}$ \\
\hline Other (ref.: White) & $\begin{array}{l}-0.359 \\
(1.430)\end{array}$ \\
\hline Female & $\begin{array}{l}0.204 \\
(0.199)\end{array}$ \\
\hline Foreign Born & $\begin{array}{l}0.740 \\
(0.578)\end{array}$ \\
\hline Mother in Home & $\begin{array}{l}0.309 \\
(0.276)\end{array}$ \\
\hline Father in Home & $\begin{array}{l}0.257 \\
(0.224)\end{array}$ \\
\hline Vocabulary & $\begin{array}{l}0.151 \\
(0.179)\end{array}$ \\
\hline Reading & $\begin{array}{l}0.205 \\
(0.188)\end{array}$ \\
\hline Math & $\begin{array}{l}0.238 \\
(0.213)\end{array}$ \\
\hline Science & $\begin{array}{l}0.354 * * \\
(0.170)\end{array}$ \\
\hline Writing & $\begin{array}{l}0.333 * * \\
(0.152)\end{array}$ \\
\hline Civics & $\begin{array}{l}0.025 \\
(0.151)\end{array}$ \\
\hline High School GPA & $\begin{array}{l}1.233^{* * *} \\
(0.208)\end{array}$ \\
\hline Highest Math Course & $\begin{array}{l}0.209 * * \\
(0.098)\end{array}$ \\
\hline Constant & $\begin{array}{l}-1.541^{*} \\
(0.825)\end{array}$ \\
\hline Observations & 3,369 \\
\hline
\end{tabular}


Table S.29. Logistic response model of high school attainment estimated with demographic, cognitive, and noncognitive covariates and the smaller sample of respondents who completed the long-form 2014 questionnaire.

\begin{tabular}{|c|c|}
\hline & High School Attainment \\
\hline Family Income & $\begin{array}{l}-0.006 \\
(0.010)\end{array}$ \\
\hline Parental Education & $0.095^{*}$ \\
\hline & $(0.050)$ \\
\hline Parental SEI & -0.005 \\
\hline & $(0.006)$ \\
\hline Sibship Size & $-0.126^{* *}$ \\
\hline & $(0.058)$ \\
\hline Hispanic or Spanish (ref.: White) & $0.466^{*}$ \\
\hline & $(0.243)$ \\
\hline American Indian or Alaskan Native (ref.: White) & - \\
\hline Asian or Pacific Islander (ref.: White) & 0.960 \\
\hline & $(1.249)$ \\
\hline Black (ref:: White) & 0.463 \\
\hline & $(0.308)$ \\
\hline Other (ref.: White) & -0.553 \\
\hline & $(1.480)$ \\
\hline Female & 0.074 \\
\hline & $(0.207)$ \\
\hline Foreign Born & 0.762 \\
\hline & $(0.680)$ \\
\hline Mother in Home & 0.294 \\
\hline & $(0.283)$ \\
\hline Father in Home & 0.196 \\
\hline & $(0.223)$ \\
\hline Vocabulary & 0.137 \\
\hline & $(0.178)$ \\
\hline Reading & 0.246 \\
\hline & $(0.190)$ \\
\hline Math & 0.247 \\
\hline & $(0.220)$ \\
\hline Science & $0.324 *$ \\
\hline & $(0.171)$ \\
\hline Writing & $0.323 * *$ \\
\hline & $(0.155)$ \\
\hline Civics & -0.014 \\
\hline & $(0.157)$ \\
\hline High School GPA & $1.096^{* * *}$ \\
\hline & $(0.221)$ \\
\hline Highest Math Course & 0.162 \\
\hline & $(0.100)$ \\
\hline Self-Esteem & 0.015 \\
\hline & $(0.088)$ \\
\hline Locus of Control & 0.065 \\
\hline & $(0.121)$ \\
\hline Effort & $0.349 * * *$ \\
\hline & $(0.099)$ \\
\hline Conscientiousness & 0.147 \\
\hline & $(0.090)$ \\
\hline Constant & -0.730 \\
\hline & $(0.866)$ \\
\hline Observations & 3,369 \\
\hline
\end{tabular}


Table S.30. Logistic response model of college entry estimated with demographic covariates and the smaller sample of respondents who completed the long-form 2014 questionnaire.

\begin{tabular}{ll}
\hline & College Entry \\
\hline Family Income & $0.012^{* * * *}$ \\
& $(0.004)$ \\
Parental Education & $0.261^{* * *}$ \\
& $(0.021)$ \\
Parental SEI & $0.008^{* * *}$ \\
& $(0.002)$ \\
Sibship Size & $-0.118^{* * *}$ \\
& $(0.025)$ \\
Hispanic or Spanish (ref.: White) & 0.082 \\
& $(0.126)$ \\
American Indian or Alaskan Native (ref.: White) & -0.583 \\
& $(0.407)$ \\
Asian or Pacific Islander (ref.: White) & $0.629^{* *}$ \\
& $(0.251)$ \\
Black (ref.: White) & $0.283^{* *}$ \\
Other (ref.: White) & $(0.143)$ \\
& -0.318 \\
Female & $(0.915)$ \\
& -0.014 \\
Foreign Born & $(0.085)$ \\
& 0.323 \\
Mother in Home & $(0.209)$ \\
Father in Home & $0.619^{* * *}$ \\
& $(0.170)$ \\
Constant & $0.386^{* * *}$ \\
& $(0.105)$ \\
Observations & $-4.291^{* * *}$ \\
& $(0.318)$ \\
& 3,245 \\
\hline & Robust standard errors in parentheses \\
& $* * * \mathrm{p}<0.01, * * \mathrm{p}<0.05, * \mathrm{p}<0.1$ \\
\end{tabular}


Table S.31. Logistic response model of college entry estimated with demographic and cognitive covariates and the smaller sample of respondents who completed the long-form 2014 questionnaire.

\begin{tabular}{|c|c|}
\hline & College Entry \\
\hline Family Income & $\begin{array}{l}0.009^{*} \\
(0.005)\end{array}$ \\
\hline Parental Education & $\begin{array}{l}0.176^{* * *} \\
(0.024)\end{array}$ \\
\hline Parental SEI & $\begin{array}{l}0.006^{* *} \\
(0.003)\end{array}$ \\
\hline Sibship Size & $\begin{array}{l}-0.078 * * \\
(0.031)\end{array}$ \\
\hline Hispanic or Spanish (ref.: White) & $\begin{array}{l}0.579 * * * \\
(0.144)\end{array}$ \\
\hline American Indian or Alaskan Native (ref.: White) & $\begin{array}{l}0.004 \\
(0.486)\end{array}$ \\
\hline Asian or Pacific Islander (ref.: White) & $\begin{array}{l}0.414 \\
(0.311)\end{array}$ \\
\hline Black (ref.: White) & $\begin{array}{l}0.820 * * * \\
(0.162)\end{array}$ \\
\hline Other (ref.: White) & $\begin{array}{l}0.548 \\
(1.266)\end{array}$ \\
\hline Female & $\begin{array}{l}-0.100 \\
(0.115)\end{array}$ \\
\hline Foreign Born & $\begin{array}{l}0.231 \\
(0.253)\end{array}$ \\
\hline Mother in Home & $\begin{array}{l}0.360^{*} \\
(0.201)\end{array}$ \\
\hline Father in Home & $\begin{array}{l}0.213^{*} \\
(0.124)\end{array}$ \\
\hline Vocabulary & $\begin{array}{l}0.400 * * * \\
(0.082)\end{array}$ \\
\hline Reading & $\begin{array}{l}0.129 \\
(0.079)\end{array}$ \\
\hline Math & $\begin{array}{l}-0.038 \\
(0.083)\end{array}$ \\
\hline Science & $\begin{array}{l}0.000 \\
(0.083)\end{array}$ \\
\hline Writing & $\begin{array}{l}-0.050 \\
(0.088)\end{array}$ \\
\hline Civics & $\begin{array}{l}0.148^{* *} \\
(0.067)\end{array}$ \\
\hline High School GPA & $\begin{array}{l}0.805^{* * * *} \\
(0.101)\end{array}$ \\
\hline Highest Math Course & $\begin{array}{l}0.541 * * * \\
(0.043)\end{array}$ \\
\hline Constant & $\begin{array}{l}-7.269 * * * \\
(0.490)\end{array}$ \\
\hline Observations & 3,245 \\
\hline
\end{tabular}


Table S.32. Logistic response model of college entry estimated with demographic, cognitive, and noncognitive covariates and the smaller sample of respondents who completed the long-form 2014 questionnaire.

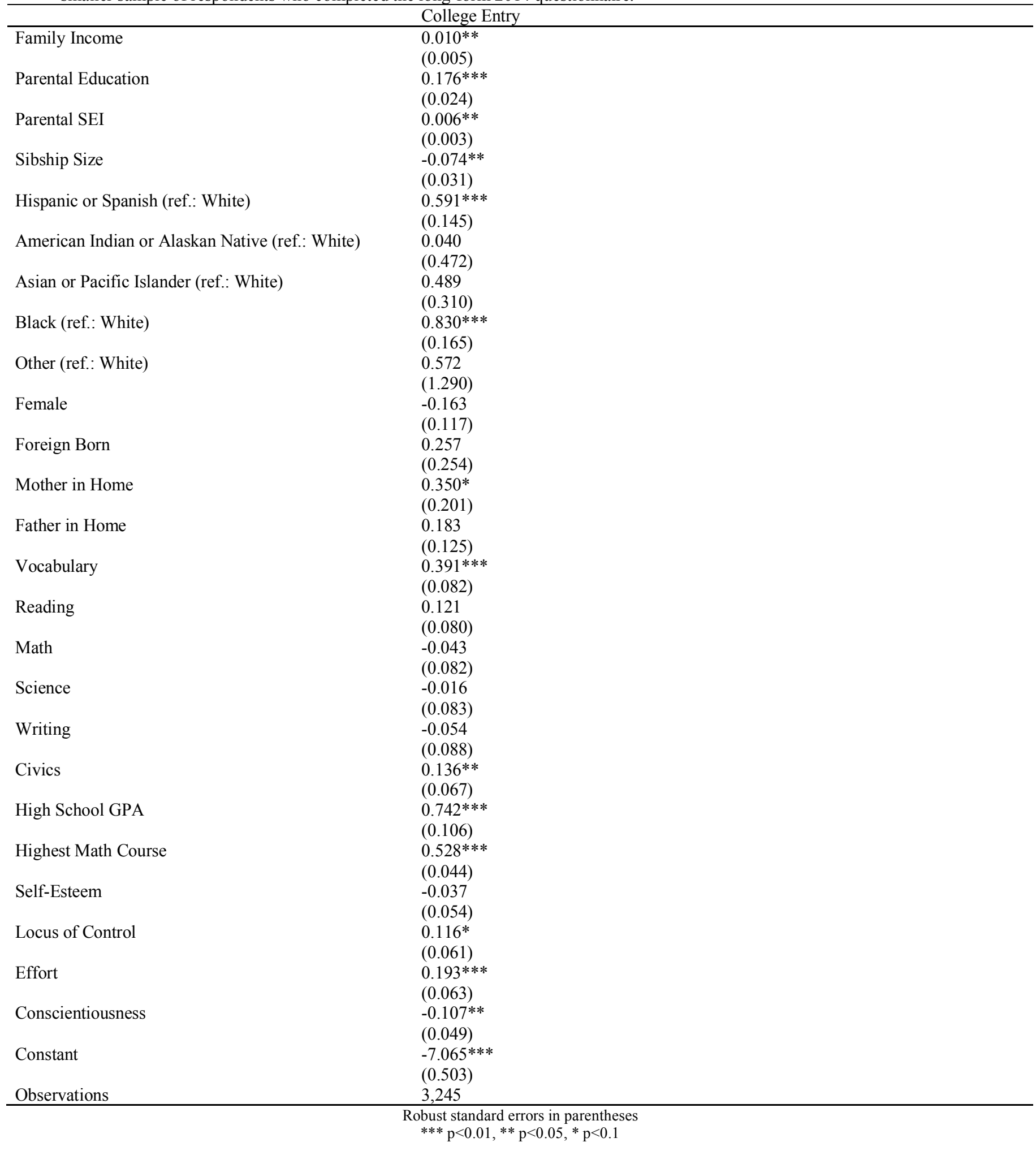


Table S.33. Logistic response model of college attainment estimated with demographic covariates and the smaller sample of respondents who completed the long-form 2014 questionnaire.

\begin{tabular}{|c|c|}
\hline & College Attainment \\
\hline Family Income & $\begin{array}{l}0.009 * \\
(0.005)\end{array}$ \\
\hline Parental Education & $\begin{array}{l}0.153 * * * \\
(0.028)\end{array}$ \\
\hline Parental SEI & $\begin{array}{l}-0.004 \\
(0.003)\end{array}$ \\
\hline Sibship Size & $\begin{array}{l}0.035 \\
(0.038)\end{array}$ \\
\hline Hispanic or Spanish (ref.: White) & $\begin{array}{l}-0.481 * * * \\
(0.161)\end{array}$ \\
\hline American Indian or Alaskan Native (ref.: White) & $\begin{array}{l}-0.435 \\
(0.579)\end{array}$ \\
\hline Asian or Pacific Islander (ref.: White) & $\begin{array}{l}0.149 \\
(0.320)\end{array}$ \\
\hline Black (ref.: White) & $\begin{array}{l}-0.546^{* * *} \\
(0.186)\end{array}$ \\
\hline Other (ref.: White) & $\begin{array}{l}0.099 \\
(1.018)\end{array}$ \\
\hline Female & $\begin{array}{l}0.081 \\
(0.106)\end{array}$ \\
\hline Foreign Born & $\begin{array}{l}0.345 \\
(0.232)\end{array}$ \\
\hline Mother in Home & $\begin{array}{l}0.174 \\
(0.243)\end{array}$ \\
\hline Father in Home & $\begin{array}{l}0.487 * * * \\
(0.141)\end{array}$ \\
\hline Constant & $\begin{array}{l}-1.955 * * * \\
(0.432)\end{array}$ \\
\hline Observations & 1,883 \\
\hline
\end{tabular}


Table S.34. Logistic response model of college attainment estimated with demographic and cognitive covariates and the smaller sample of respondents who completed the long-form 2014 questionnaire.

\begin{tabular}{|c|c|}
\hline & College Attainment \\
\hline Family Income & $\begin{array}{l}0.008 \\
(0.005)\end{array}$ \\
\hline Parental Education & $\begin{array}{l}0.120 * * * \\
(0.029)\end{array}$ \\
\hline Parental SEI & $\begin{array}{l}-0.003 \\
(0.003)\end{array}$ \\
\hline Sibship Size & $\begin{array}{l}0.045 \\
(0.039)\end{array}$ \\
\hline Hispanic or Spanish (ref.: White) & $\begin{array}{l}-0.377 * * \\
(0.168)\end{array}$ \\
\hline American Indian or Alaskan Native (ref.: White) & $\begin{array}{l}-0.121 \\
(0.745)\end{array}$ \\
\hline Asian or Pacific Islander (ref:: White) & $\begin{array}{l}-0.167 \\
(0.346)\end{array}$ \\
\hline Black (ref.: White) & $\begin{array}{l}-0.300 \\
(0.207)\end{array}$ \\
\hline Other (ref.: White) & $\begin{array}{l}0.310 \\
(0.880)\end{array}$ \\
\hline Female & $\begin{array}{l}0.055 \\
(0.127)\end{array}$ \\
\hline Foreign Born & $\begin{array}{l}0.328 \\
(0.237)\end{array}$ \\
\hline Mother in Home & $\begin{array}{l}0.000 \\
(0.276)\end{array}$ \\
\hline Father in Home & $\begin{array}{l}0.385^{* *} \\
(0.150)\end{array}$ \\
\hline Vocabulary & $\begin{array}{l}0.001 \\
(0.101)\end{array}$ \\
\hline Reading & $\begin{array}{l}-0.093 \\
(0.096)\end{array}$ \\
\hline Math & $\begin{array}{l}0.153 \\
(0.095)\end{array}$ \\
\hline Science & $\begin{array}{l}-0.054 \\
(0.104)\end{array}$ \\
\hline Writing & $\begin{array}{l}-0.053 \\
(0.108)\end{array}$ \\
\hline Civics & $\begin{array}{l}0.115 \\
(0.075)\end{array}$ \\
\hline High School GPA & $\begin{array}{l}0.659 * * * \\
(0.124)\end{array}$ \\
\hline Highest Math Course & $\begin{array}{l}0.335^{* * *} \\
(0.058)\end{array}$ \\
\hline Constant & $\begin{array}{l}-4.752 * * * \\
(0.612)\end{array}$ \\
\hline Observations & 1,883 \\
\hline
\end{tabular}


Table S.35. Logistic response model of college attainment estimated with demographic, cognitive, and noncognitive covariates and the smaller sample of respondents who completed the long-form 2014 questionnaire.

\begin{tabular}{|c|c|}
\hline 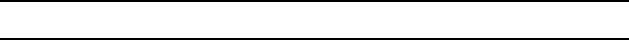 & College Attainment \\
\hline Family Income & $\begin{array}{l}0.008 \\
(0.005)\end{array}$ \\
\hline Parental Education & $\begin{array}{l}0.120 * * * \\
(0.029)\end{array}$ \\
\hline Parental SEI & $\begin{array}{l}-0.004 \\
(0.003)\end{array}$ \\
\hline Sibship Size & $\begin{array}{l}0.048 \\
(0.039)\end{array}$ \\
\hline Hispanic or Spanish (ref.: White) & $\begin{array}{l}-0.389 * * \\
(0.168)\end{array}$ \\
\hline American Indian or Alaskan Native (ref.: White) & $\begin{array}{l}-0.158 \\
(0.751)\end{array}$ \\
\hline Asian or Pacific Islander (ref.: White) & $\begin{array}{l}-0.159 \\
(0.352)\end{array}$ \\
\hline Black (ref:: White) & $\begin{array}{l}-0.336 \\
(0.212)\end{array}$ \\
\hline Other (ref.: White) & $\begin{array}{l}0.320 \\
(0.896)\end{array}$ \\
\hline Female & $\begin{array}{l}0.065 \\
(0.128)\end{array}$ \\
\hline Foreign Born & $\begin{array}{l}0.335 \\
(0.241)\end{array}$ \\
\hline Mother in Home & $\begin{array}{l}-0.022 \\
(0.277)\end{array}$ \\
\hline Father in Home & $\begin{array}{l}0.376^{* *} \\
(0.151)\end{array}$ \\
\hline Vocabulary & $\begin{array}{l}0.015 \\
(0.100)\end{array}$ \\
\hline Reading & $\begin{array}{l}-0.073 \\
(0.097)\end{array}$ \\
\hline Math & $\begin{array}{l}0.163^{*} \\
(0.095)\end{array}$ \\
\hline Science & $\begin{array}{l}-0.056 \\
(0.106)\end{array}$ \\
\hline Writing & $\begin{array}{l}-0.057 \\
(0.109)\end{array}$ \\
\hline Civics & $\begin{array}{l}0.115 \\
(0.076)\end{array}$ \\
\hline High School GPA & $\begin{array}{l}0.588 * * * \\
(0.128)\end{array}$ \\
\hline Highest Math Course & $\begin{array}{l}0.316^{* * *} \\
(0.058)\end{array}$ \\
\hline Self-Esteem & $\begin{array}{l}0.088 \\
(0.058)\end{array}$ \\
\hline Locus of Control & $\begin{array}{l}-0.043 \\
(0.077)\end{array}$ \\
\hline Effort & $\begin{array}{l}0.133^{*} \\
(0.072)\end{array}$ \\
\hline Conscientiousness & $\begin{array}{l}0.031 \\
(0.061)\end{array}$ \\
\hline Constant & $\begin{array}{l}-4.496 * * * \\
(0.623)\end{array}$ \\
\hline Observations & 1,883 \\
\hline
\end{tabular}


Table S.36. Logistic response model of grad school entry estimated with demographic covariates and the smaller sample of respondents who completed the long-form 2014 questionnaire.

\begin{tabular}{|c|c|}
\hline & Grad School Entry \\
\hline Family Income & $\begin{array}{l}0.007 \\
(0.006)\end{array}$ \\
\hline Parental Education & $\begin{array}{l}0.090 * * \\
(0.036)\end{array}$ \\
\hline Parental SEI & $\begin{array}{l}0.001 \\
(0.004)\end{array}$ \\
\hline Sibship Size & $\begin{array}{l}-0.027 \\
(0.043)\end{array}$ \\
\hline Hispanic or Spanish (ref.: White) & $\begin{array}{l}-0.343 \\
(0.222)\end{array}$ \\
\hline American Indian or Alaskan Native (ref.: White) & $\begin{array}{l}-0.875 \\
(0.900)\end{array}$ \\
\hline Asian or Pacific Islander (ref.: White) & $\begin{array}{l}0.242 \\
(0.314)\end{array}$ \\
\hline Black (ref.: White) & $\begin{array}{l}0.070 \\
(0.222)\end{array}$ \\
\hline Other (ref.: White) & - \\
\hline Female & $\begin{array}{l}-0.190 \\
(0.126)\end{array}$ \\
\hline Foreign Born & $\begin{array}{l}0.194 \\
(0.286)\end{array}$ \\
\hline Mother in Home & $\begin{array}{l}0.489 \\
(0.372)\end{array}$ \\
\hline Father in Home & $\begin{array}{l}-0.162 \\
(0.194)\end{array}$ \\
\hline Constant & $\begin{array}{l}-2.474 * * * \\
(0.642)\end{array}$ \\
\hline Observations & 1,282 \\
\hline
\end{tabular}


Table S.37. Logistic response model of grad school entry estimated with demographic and cognitive covariates and the smaller sample of respondents who completed the long-form 2014 questionnaire.

\begin{tabular}{|c|c|c|c|}
\hline & & & Grad School Entry \\
\hline & & Family Income & $\begin{array}{l}0.007 \\
(0.006)\end{array}$ \\
\hline & & Parental Education & $\begin{array}{l}0.059 \\
(0.038)\end{array}$ \\
\hline & & Parental SEI & $\begin{array}{l}0.002 \\
(0.004)\end{array}$ \\
\hline & & Sibship Size & $\begin{array}{l}-0.011 \\
(0.044)\end{array}$ \\
\hline & & Hispanic or Spanish (ref.: White) & $\begin{array}{l}-0.242 \\
(0.225)\end{array}$ \\
\hline & & American Indian or Alaskan Native (ref.: White) & $\begin{array}{l}-0.589 \\
(1.038)\end{array}$ \\
\hline & & Asian or Pacific Islander (ref.: White) & $\begin{array}{l}0.117 \\
(0.318)\end{array}$ \\
\hline & & Black (ref.: White) & $\begin{array}{l}0.396 * \\
(0.232)\end{array}$ \\
\hline & & Other (ref:: White) & - \\
\hline & & Female & $\begin{array}{l}-0.143 \\
(0.144)\end{array}$ \\
\hline & & Foreign Born & $\begin{array}{l}0.203 \\
(0.288)\end{array}$ \\
\hline & & Mother in Home & $\begin{array}{l}0.362 \\
(0.385)\end{array}$ \\
\hline & & Father in Home & $\begin{array}{l}-0.193 \\
(0.198)\end{array}$ \\
\hline & & Vocabulary & $\begin{array}{l}-0.047 \\
(0.121)\end{array}$ \\
\hline & & Reading & $\begin{array}{l}0.061 \\
(0.106)\end{array}$ \\
\hline & & Math & $\begin{array}{l}0.187 \\
(0.115)\end{array}$ \\
\hline & & Science & $\begin{array}{l}0.074 \\
(0.124)\end{array}$ \\
\hline & & Writing & $\begin{array}{l}-0.027 \\
(0.130)\end{array}$ \\
\hline & & Civics & $\begin{array}{l}0.158 \\
(0.100)\end{array}$ \\
\hline & & High School GPA & $\begin{array}{l}0.398 * * * \\
(0.141)\end{array}$ \\
\hline & & Highest Math Course & $\begin{array}{l}0.225^{* * *} \\
(0.087)\end{array}$ \\
\hline & & Constant & $\begin{array}{l}-4.712 * * * \\
(0.861)\end{array}$ \\
\hline & & Observations & 1,282 \\
\hline
\end{tabular}


Table S.38. Logistic response model of grad school entry estimated with demographic, cognitive, and noncognitive covariates and the smaller sample of respondents who completed the long-form 2014 questionnaire.

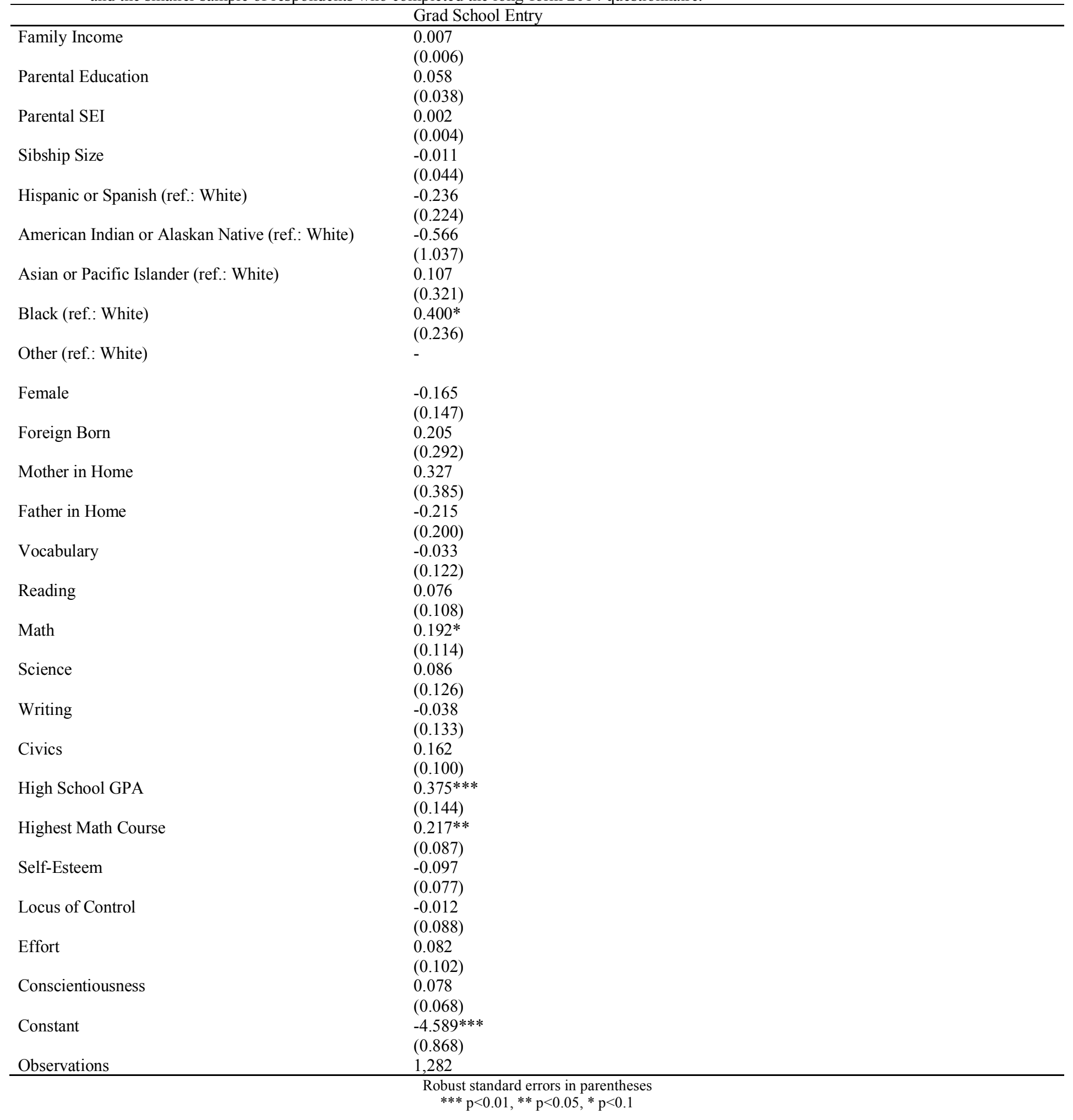


Table S.39. Logistic response model of grad school attainment estimated with demographic covariates and the smaller sample of respondents who completed the long-form 2014 questionnaire.

\begin{tabular}{|c|c|}
\hline & Grad School Attainment \\
\hline Family Income & $\begin{array}{l}0.017 * \\
(0.009)\end{array}$ \\
\hline Parental Education & $\begin{array}{l}0.050 \\
(0.057)\end{array}$ \\
\hline Parental SEI & $\begin{array}{l}-0.004 \\
(0.006)\end{array}$ \\
\hline Sibship Size & $\begin{array}{l}-0.127^{*} \\
(0.072)\end{array}$ \\
\hline Hispanic or Spanish (ref.: White) & $\begin{array}{l}-0.460 \\
(0.360)\end{array}$ \\
\hline American Indian or Alaskan Native (ref.: White) & $\begin{array}{l}0.714 \\
(1.827)\end{array}$ \\
\hline Asian or Pacific Islander (ref.: White) & $\begin{array}{l}0.092 \\
(0.438)\end{array}$ \\
\hline Black (ref.: White) & $\begin{array}{l}-0.226 \\
(0.378)\end{array}$ \\
\hline Other (ref.: White) & $\begin{array}{l}-0.881 \\
(1.168)\end{array}$ \\
\hline Female & $\begin{array}{l}-0.025 \\
(0.213)\end{array}$ \\
\hline Foreign Born & $\begin{array}{l}0.345 \\
(0.414)\end{array}$ \\
\hline Mother in Home & $\begin{array}{l}-0.087 \\
(0.674)\end{array}$ \\
\hline Father in Home & $\begin{array}{l}-0.320 \\
(0.304)\end{array}$ \\
\hline Constant & $\begin{array}{l}-0.149 \\
(1.025)\end{array}$ \\
\hline Observations & 435 \\
\hline
\end{tabular}


Table S.40. Logistic response model of grad school attainment estimated with demographic and cognitive covariates and the smaller sample of respondents who completed the long-form 2014 questionnaire.

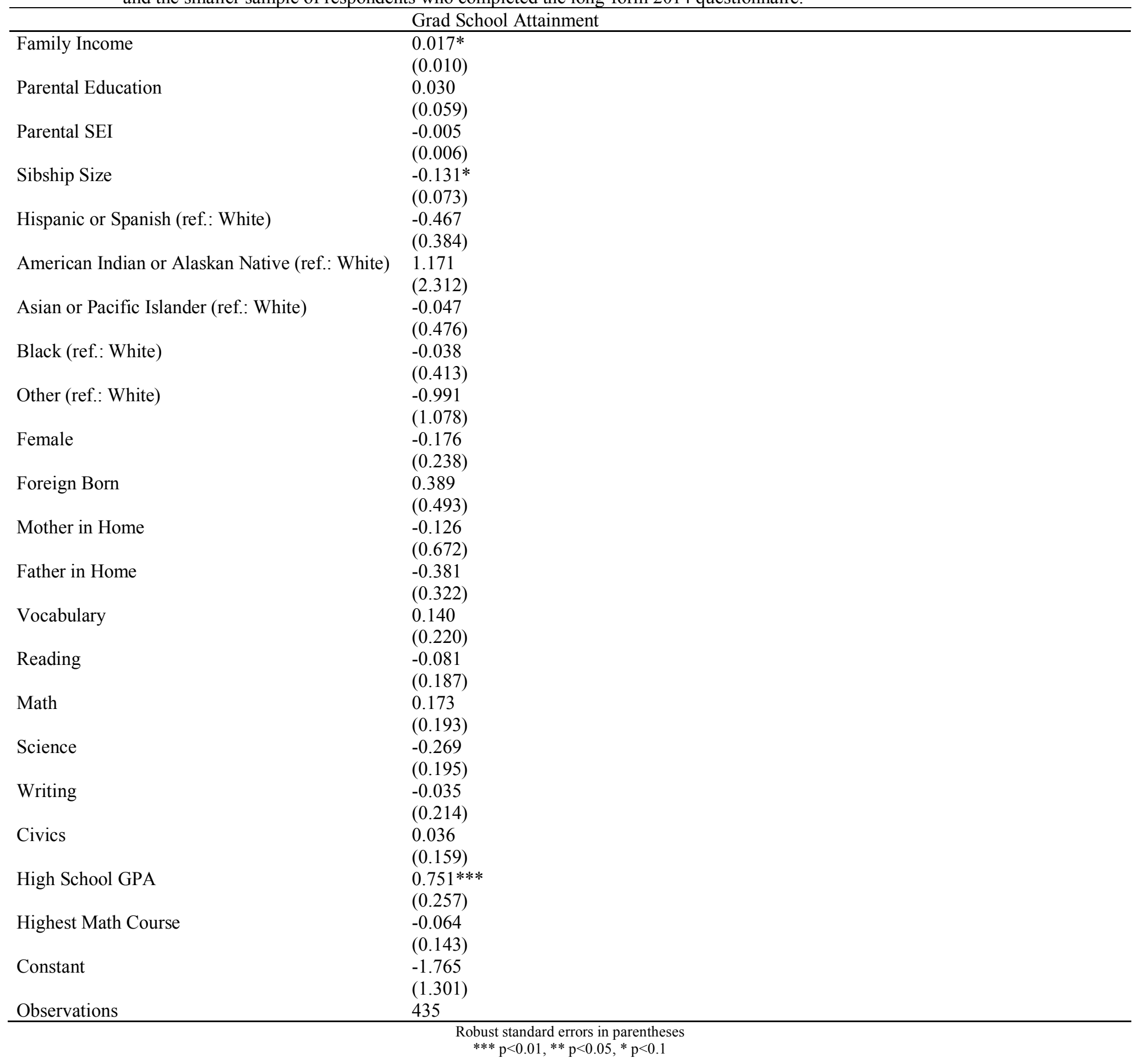


Table S.41. Logistic response model of grad school attainment estimated with demographic, cognitive, and noncognitive covariates and the smaller sample of respondents who completed the long-form 2014 questionnaire.

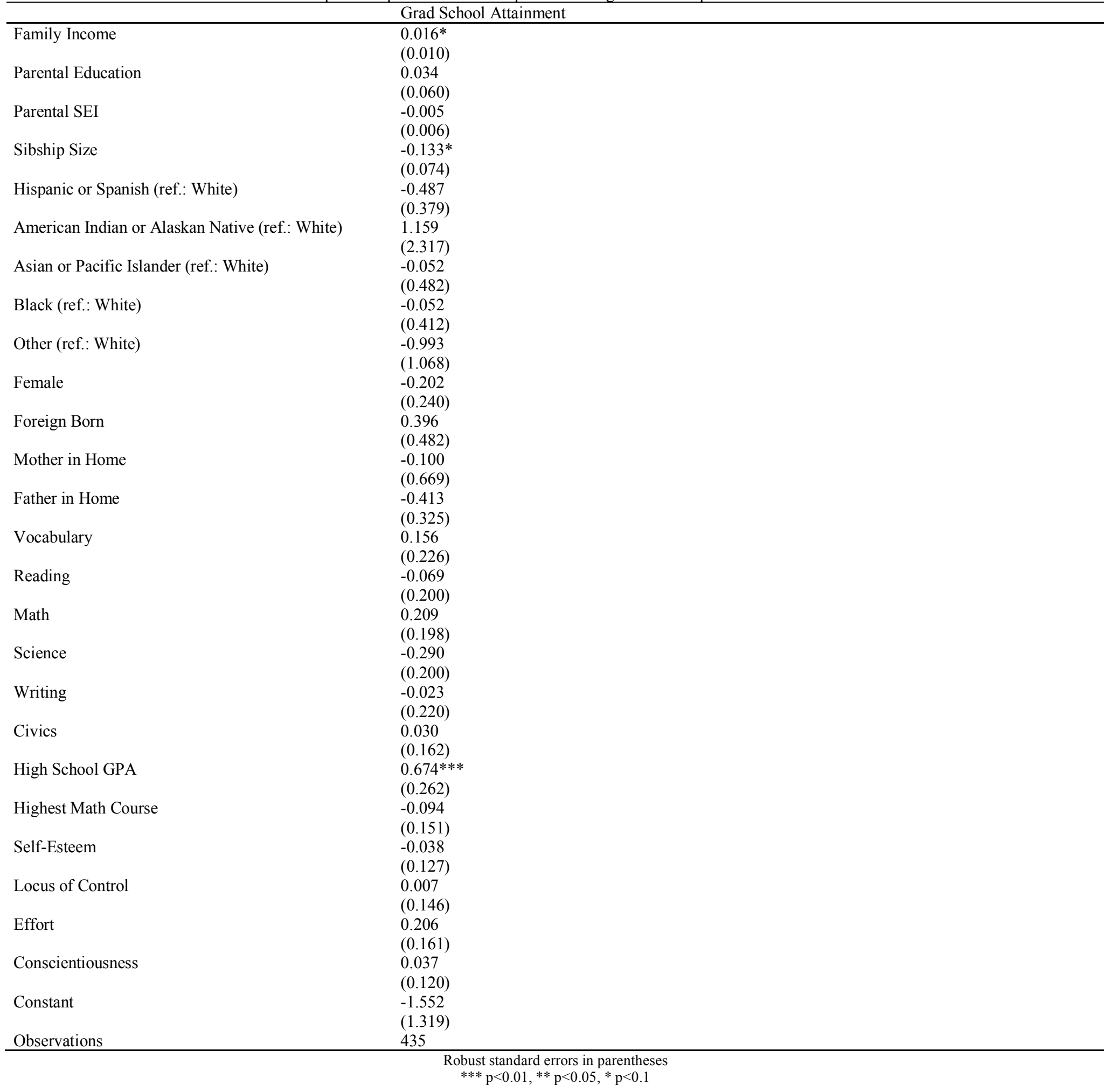


Table S.42. Logistic response model of 2014 high school attainment estimated with demographic covariates and the smaller sample of respondents who completed the long-form 2014 questionnaire.

\begin{tabular}{ll}
\hline & High School Attainment \\
\hline Family Income & -0.012 \\
& $(0.011)$ \\
Parental Education & $0.272^{* * *}$ \\
& $(0.051)$ \\
Parental SEI & -0.001 \\
& $(0.006)$ \\
Sibship Size & $-0.217^{* * *}$ \\
& $(0.062)$ \\
Hispanic or Spanish (ref.: White) & -0.310 \\
& $(0.272)$ \\
American Indian or Alaskan Native (ref.: White) & - \\
& - \\
Asian or Pacific Islander (ref.: White) & \\
Black (ref.: White) & -0.445 \\
& $(0.296)$ \\
Other (ref.: White) & - \\
& \\
Female & 0.287 \\
Foreign Born & $(0.198)$ \\
& 0.976 \\
Mother in Home & $(0.704)$ \\
Father in Home & $1.011^{* * *}$ \\
Constant & $(0.268)$ \\
Observations & $0.437 *$ \\
& $(0.242)$ \\
& -0.215 \\
& $(0.631)$ \\
& 3,207 \\
\hline$* * * 0$ & $\mathrm{p}<0.01, * * \mathrm{p}<0.05, * \mathrm{p}<0.1$ \\
&
\end{tabular}


Table S.43. Logistic response model of 2014 high school attainment estimated with demographic and cognitive covariates and the smaller sample of respondents who completed the long-form 2014 questionnaire.

\begin{tabular}{|c|c|}
\hline & High School Attainment \\
\hline Family Income & $\begin{array}{l}-0.015 \\
(0.012)\end{array}$ \\
\hline Parental Education & $\begin{array}{l}0.135^{* *} \\
(0.058)\end{array}$ \\
\hline Parental SEI & $\begin{array}{l}-0.008 \\
(0.006)\end{array}$ \\
\hline Sibship Size & $\begin{array}{l}-0.175^{* *} \\
(0.069)\end{array}$ \\
\hline Hispanic or Spanish (ref.: White) & $\begin{array}{l}0.273 \\
(0.281)\end{array}$ \\
\hline American Indian or Alaskan Native (ref.: White) & - \\
\hline Asian or Pacific Islander (ref.: White) & - \\
\hline Black (ref.: White) & $\begin{array}{l}0.171 \\
(0.330)\end{array}$ \\
\hline Other (ref.: White) & - \\
\hline Female & $\begin{array}{l}0.175 \\
(0.231)\end{array}$ \\
\hline Foreign Born & $\begin{array}{l}1.156 \\
(0.715)\end{array}$ \\
\hline Mother in Home & $\begin{array}{l}0.753^{* *} \\
(0.294)\end{array}$ \\
\hline Father in Home & $\begin{array}{l}0.131 \\
(0.262)\end{array}$ \\
\hline Vocabulary & $\begin{array}{l}0.007 \\
(0.195)\end{array}$ \\
\hline Reading & $\begin{array}{l}0.211 \\
(0.225)\end{array}$ \\
\hline Math & $\begin{array}{l}0.210 \\
(0.219)\end{array}$ \\
\hline Science & $\begin{array}{l}0.488^{* * * *} \\
(0.177)\end{array}$ \\
\hline Writing & $\begin{array}{l}0.265 \\
(0.195)\end{array}$ \\
\hline Civics & $\begin{array}{l}-0.026 \\
(0.182)\end{array}$ \\
\hline High School GPA & $\begin{array}{l}1.266^{* * * *} \\
(0.276)\end{array}$ \\
\hline Highest Math Course & $\begin{array}{l}0.268 \\
(0.238)\end{array}$ \\
\hline Constant & $\begin{array}{l}-1.408 \\
(1.033)\end{array}$ \\
\hline Observations & 3,207 \\
\hline
\end{tabular}


Table S.44. Logistic response model of 2014 high school attainment estimated with demographic, cognitive, and noncognitive covariates and the smaller sample of respondents who completed the long-form 2014 questionnaire.

\begin{tabular}{|c|c|c|c|}
\hline & & & High School Attainment \\
\hline & & Family Income & $\begin{array}{l}-0.014 \\
(0.012)\end{array}$ \\
\hline & & Parental Education & $\begin{array}{l}0.127^{* *} \\
(0.060)\end{array}$ \\
\hline & & Parental SEI & $\begin{array}{l}-0.008 \\
(0.007)\end{array}$ \\
\hline & & Sibship Size & $\begin{array}{l}-0.185^{* * *} \\
(0.071)\end{array}$ \\
\hline & & Hispanic or Spanish (ref.: White) & $\begin{array}{l}0.241 \\
(0.282)\end{array}$ \\
\hline & & American Indian or Alaskan Native (ref.: White) & - \\
\hline & & Asian or Pacific Islander (ref.: White) & - \\
\hline & & Black (ref.: White) & $\begin{array}{l}0.128 \\
(0.338)\end{array}$ \\
\hline & & Other (ref.: White) & - \\
\hline & & Female & $\begin{array}{l}0.043 \\
(0.241)\end{array}$ \\
\hline & & Foreign Born & $\begin{array}{l}1.326 \\
(0.895)\end{array}$ \\
\hline & & Mother in Home & $\begin{array}{l}0.763 * * \\
(0.300)\end{array}$ \\
\hline & & Father in Home & $\begin{array}{l}0.048 \\
(0.258)\end{array}$ \\
\hline & & Vocabulary & $\begin{array}{l}-0.007 \\
(0.192)\end{array}$ \\
\hline & & Reading & $\begin{array}{l}0.226 \\
(0.227)\end{array}$ \\
\hline & & Math & $\begin{array}{l}0.210 \\
(0.228)\end{array}$ \\
\hline & & Science & $\begin{array}{l}0.458 * * \\
(0.181)\end{array}$ \\
\hline & & Writing & $\begin{array}{l}0.241 \\
(0.196)\end{array}$ \\
\hline & & Civics & $\begin{array}{l}-0.048 \\
(0.182)\end{array}$ \\
\hline & & High School GPA & $\begin{array}{l}1.165^{* * *} \\
(0.279)\end{array}$ \\
\hline & & Highest Math Course & $\begin{array}{l}0.226 \\
(0.249)\end{array}$ \\
\hline & & Self-Esteem & $\begin{array}{l}0.012 \\
(0.108)\end{array}$ \\
\hline & & Locus of Control & $\begin{array}{l}0.070 \\
(0.125)\end{array}$ \\
\hline & & Effort & $\begin{array}{l}0.329^{* * *} \\
(0.123)\end{array}$ \\
\hline & & Constant & $\begin{array}{l}-0.748 \\
(1.105)\end{array}$ \\
\hline & & Observations & 3,207 \\
\hline
\end{tabular}


Table S.45. Logistic response model of 2014 college entry estimated with demographic covariates and the smaller sample of respondents who completed the long-form 2014 questionnaire.

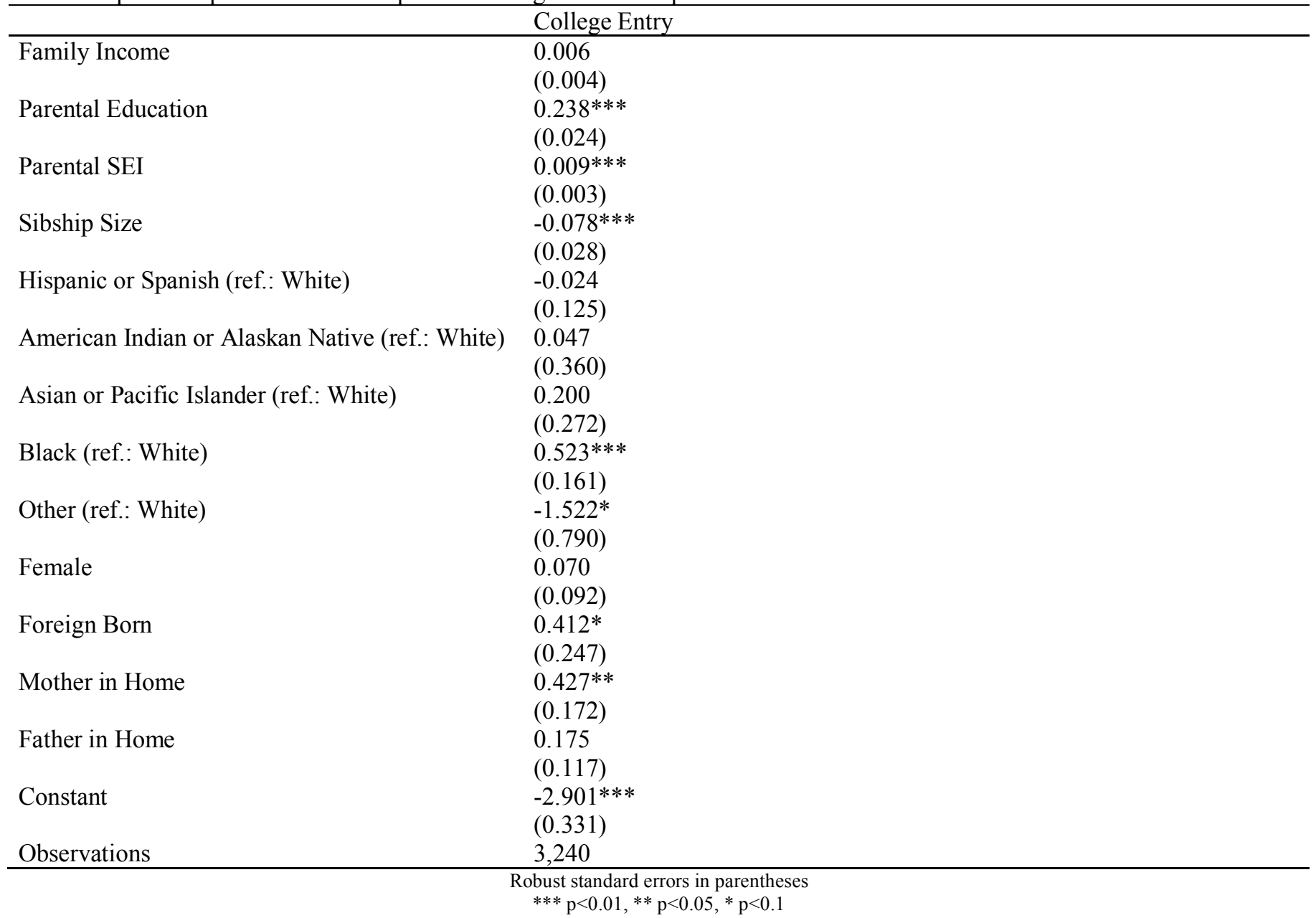


Table S.46. Logistic response model of 2014 college entry estimated with demographic and cognitive covariates and the smaller sample of respondents who completed the long-form 2014 questionnaire.

\begin{tabular}{|c|c|}
\hline & College Entry \\
\hline Family Income & $\begin{array}{l}-0.000 \\
(0.005)\end{array}$ \\
\hline Parental Education & $\begin{array}{l}0.161 * * * \\
(0.028)\end{array}$ \\
\hline Parental SEI & $\begin{array}{l}0.006^{*} \\
(0.003)\end{array}$ \\
\hline Sibship Size & $\begin{array}{l}-0.032 \\
(0.033)\end{array}$ \\
\hline Hispanic or Spanish (ref.: White) & $\begin{array}{l}0.337 * * \\
(0.139)\end{array}$ \\
\hline American Indian or Alaskan Native (ref.: White) & $\begin{array}{l}0.612 \\
(0.383)\end{array}$ \\
\hline Asian or Pacific Islander (ref.: White) & $\begin{array}{l}-0.045 \\
(0.311)\end{array}$ \\
\hline Black (ref.: White) & $\begin{array}{l}0.936 * * * \\
(0.189)\end{array}$ \\
\hline Other (ref.: White) & $\begin{array}{l}-1.108 \\
(1.044)\end{array}$ \\
\hline Female & $\begin{array}{l}0.080 \\
(0.115)\end{array}$ \\
\hline Foreign Born & $\begin{array}{l}0.340 \\
(0.263)\end{array}$ \\
\hline Mother in Home & $\begin{array}{l}0.211 \\
(0.199)\end{array}$ \\
\hline Father in Home & $\begin{array}{l}-0.007 \\
(0.132)\end{array}$ \\
\hline Vocabulary & $\begin{array}{l}0.309 * * * \\
(0.080)\end{array}$ \\
\hline Reading & $\begin{array}{l}0.112 \\
(0.088)\end{array}$ \\
\hline Math & $\begin{array}{l}-0.080 \\
(0.088)\end{array}$ \\
\hline Science & $\begin{array}{l}0.180^{*} \\
(0.094)\end{array}$ \\
\hline Writing & $\begin{array}{l}-0.092 \\
(0.091)\end{array}$ \\
\hline Civics & $\begin{array}{l}0.054 \\
(0.068)\end{array}$ \\
\hline High School GPA & $\begin{array}{l}0.523 * * * \\
(0.103)\end{array}$ \\
\hline Highest Math Course & $\begin{array}{l}0.408 * * * \\
(0.044)\end{array}$ \\
\hline Constant & $\begin{array}{l}-4.484 * * * \\
(0.481)\end{array}$ \\
\hline Observations & 3,240 \\
\hline
\end{tabular}


Table S.47. Logistic response model of 2014 college entry estimated with demographic, cognitive, and noncognitive covariates and the smaller sample of respondents who completed the long-form 2014 questionnaire.

\begin{tabular}{|c|c|}
\hline 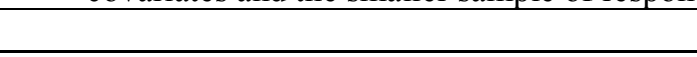 & College Entry \\
\hline Family Income & $\begin{array}{l}0.000 \\
(0.005)\end{array}$ \\
\hline Parental Education & $\begin{array}{l}0.162 * * * \\
(0.028)\end{array}$ \\
\hline Parental SEI & $\begin{array}{l}0.006^{*} \\
(0.003)\end{array}$ \\
\hline Sibship Size & $\begin{array}{l}-0.033 \\
(0.033)\end{array}$ \\
\hline Hispanic or Spanish (ref.: White) & $\begin{array}{l}0.343^{* *} \\
(0.140)\end{array}$ \\
\hline American Indian or Alaskan Native (ref.: White) & $\begin{array}{l}0.627 \\
(0.386)\end{array}$ \\
\hline Asian or Pacific Islander (ref:: White) & $\begin{array}{l}-0.052 \\
(0.313)\end{array}$ \\
\hline Black (ref.: White) & $\begin{array}{l}0.965 * * * \\
(0.192)\end{array}$ \\
\hline Other (ref.: White) & $\begin{array}{l}-1.105 \\
(1.053)\end{array}$ \\
\hline Female & $\begin{array}{l}0.071 \\
(0.117)\end{array}$ \\
\hline Foreign Born & $\begin{array}{l}0.343 \\
(0.264)\end{array}$ \\
\hline Mother in Home & $\begin{array}{l}0.215 \\
(0.199)\end{array}$ \\
\hline Father in Home & $\begin{array}{l}-0.014 \\
(0.131)\end{array}$ \\
\hline Vocabulary & $\begin{array}{l}0.313 * * * \\
(0.081)\end{array}$ \\
\hline Reading & $\begin{array}{l}0.120 \\
(0.088)\end{array}$ \\
\hline Math & $\begin{array}{l}-0.083 \\
(0.088)\end{array}$ \\
\hline Science & $\begin{array}{l}0.186^{* *} \\
(0.094)\end{array}$ \\
\hline Writing & $\begin{array}{l}-0.089 \\
(0.091)\end{array}$ \\
\hline Civics & $\begin{array}{l}0.059 \\
(0.068)\end{array}$ \\
\hline High School GPA & $\begin{array}{l}0.527 * * * \\
(0.109)\end{array}$ \\
\hline Highest Math Course & $\begin{array}{l}0.409 * * * \\
(0.045)\end{array}$ \\
\hline Self-Esteem & $\begin{array}{l}-0.045 \\
(0.052)\end{array}$ \\
\hline Locus of Control & $\begin{array}{l}-0.051 \\
(0.060)\end{array}$ \\
\hline Effort & $\begin{array}{l}0.029 \\
(0.059)\end{array}$ \\
\hline Constant & $\begin{array}{l}-4.521 * * * \\
(0.497)\end{array}$ \\
\hline Observations & 3,240 \\
\hline
\end{tabular}


Table S.48. Logistic response model of 2014 college attainment estimated with demographic covariates and the smaller sample of respondents who completed the long-form 2014 questionnaire.

\begin{tabular}{ll}
\hline & College Attainment \\
\hline Family Income & $0.018^{* * *}$ \\
& $(0.005)$ \\
Parental Education & $0.173^{* * *}$ \\
Parental SEI & $(0.025)$ \\
& 0.001 \\
Sibship Size & $(0.003)$ \\
& -0.030 \\
Hispanic or Spanish (ref.: White) & $(0.032)$ \\
& 0.077 \\
American Indian or Alaskan Native (ref.: White) & $(0.144)$ \\
& -0.281 \\
Asian or Pacific Islander (ref.: White) & $(0.447)$ \\
Black (ref.: White) & $0.895^{* *}$ \\
& $(0.351)$ \\
Other (ref.: White) & 0.088 \\
& $(0.173)$ \\
Female & 0.012 \\
& $(1.019)$ \\
Foreign Born & $0.208^{* *}$ \\
& $(0.097)$ \\
Mother in Home & 0.279 \\
Father in Home & $(0.221)$ \\
& $0.379^{*}$ \\
Constant & $(0.195)$ \\
Observations & $0.399^{* * *}$ \\
\hline & $(0.123)$ \\
& $-2.707^{* * *}$ \\
& $(0.381)$ \\
2,387 \\
\hline
\end{tabular}


Table S.49. Logistic response model of 2014 college attainment estimated with demographic and cognitive covariates and the smaller sample of respondents who completed the long-form 2014 questionnaire.

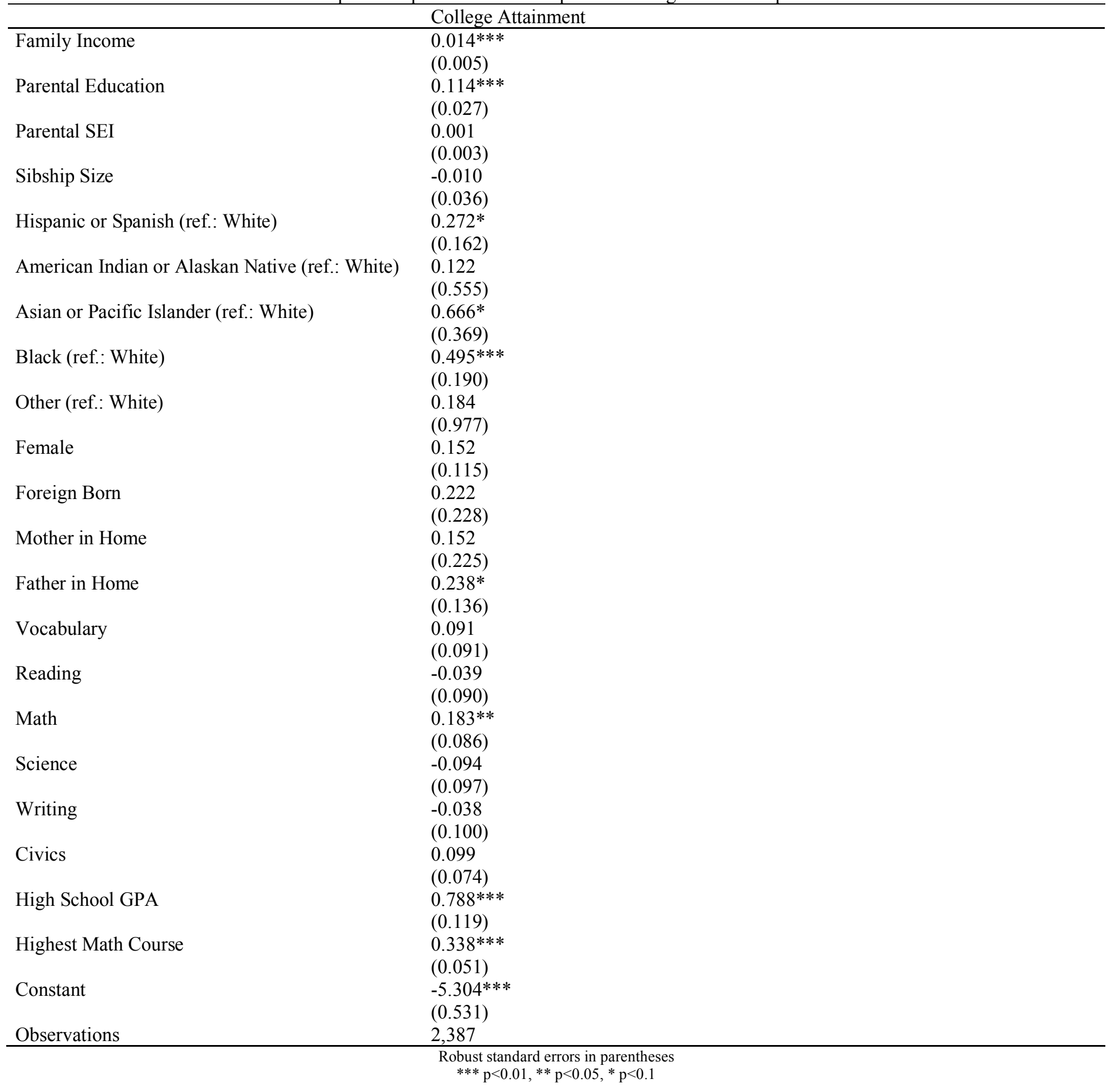


Table S.50. Logistic response model of 2014 college attainment estimated with demographic, cognitive, and noncognitive covariates and the smaller sample of respondents who completed the long-form 2014 questionnaire.

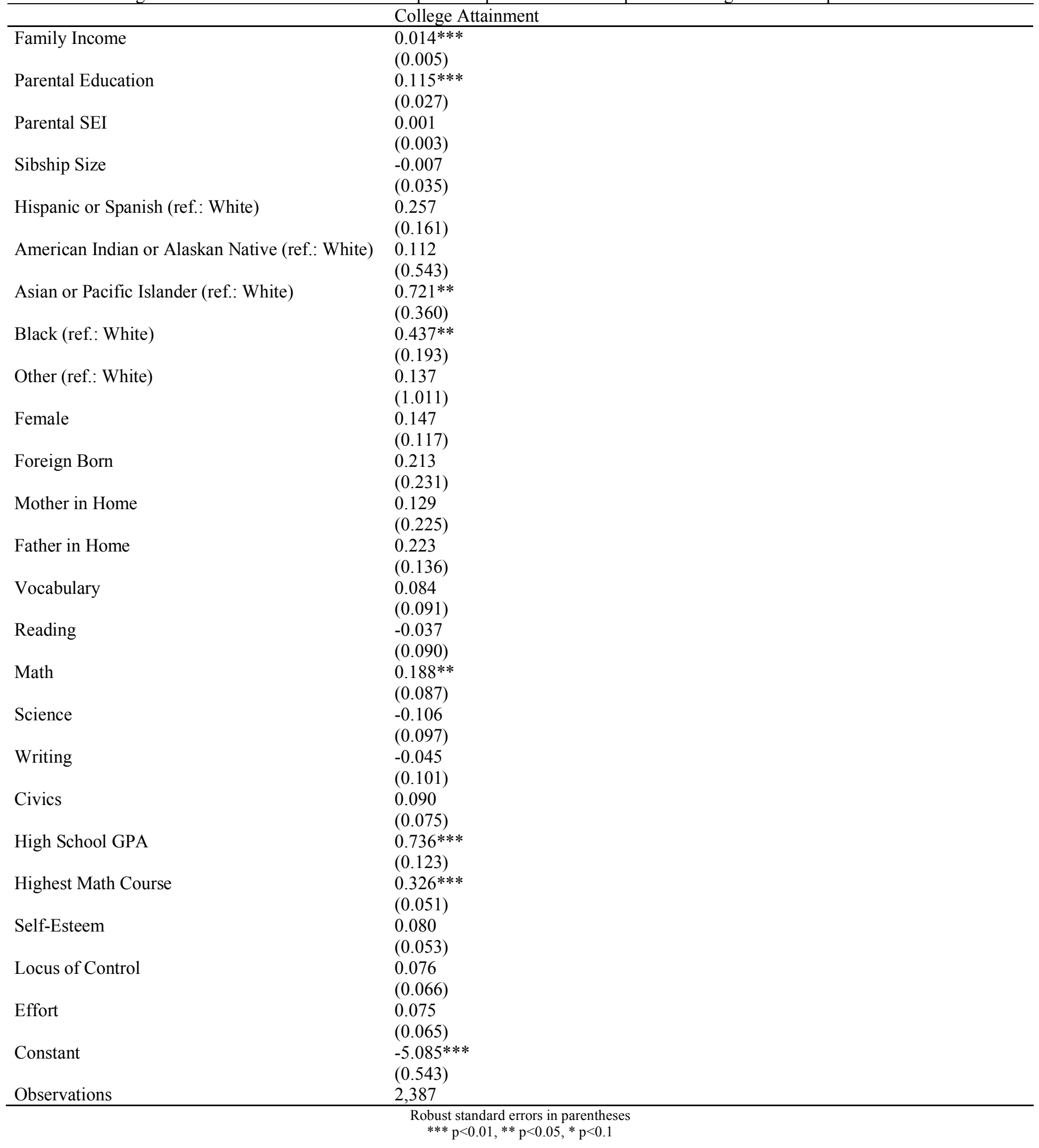


Table S.51. Logistic response model of 2014 grad school entry estimated with demographic covariates and the smaller sample of respondents who completed the long-form 2014 questionnaire.

\begin{tabular}{ll}
\hline & Grad School Entry \\
\hline Family Income & 0.003 \\
& $(0.005)$ \\
Parental Education & $0.096^{* * *}$ \\
Parental SEI & $(0.028)$ \\
& -0.002 \\
Sibship Size & $(0.003)$ \\
& 0.008 \\
Hispanic or Spanish (ref.: White) & $(0.038)$ \\
& 0.033 \\
American Indian or Alaskan Native (ref.: White) $)$ & $(0.162)$ \\
& -0.279 \\
Asian or Pacific Islander (ref.: White) & $0.484)$ \\
& 0.336 \\
Black (ref.: White) & $(0.269)$ \\
& 0.219 \\
Other (ref.: White) & $(0.173)$ \\
Female & - \\
Foreign Born & -0.067 \\
& $(0.107)$ \\
Mother in Home & -0.073 \\
Father in Home & $(0.235)$ \\
Constant & 0.433 \\
Observations & $(0.267)$ \\
& -0.114 \\
& $(0.142)$ \\
& $-1.832^{* * *}$ \\
& $(0.454)$ \\
& 1,643 \\
\hline & Robust standard errors in parentheses \\
&
\end{tabular}


Table S.52. Logistic response model of 2014 grad school entry estimated with demographic and cognitive covariates and the smaller sample of respondents who completed the long-form 2014 questionnaire.

\begin{tabular}{|c|c|}
\hline+ & Grad School Entry \\
\hline Family Income & $\begin{array}{l}0.002 \\
(0.005)\end{array}$ \\
\hline Parental Education & $\begin{array}{l}0.073 * * \\
(0.030)\end{array}$ \\
\hline Parental SEI & $\begin{array}{l}-0.002 \\
(0.003)\end{array}$ \\
\hline Sibship Size & $\begin{array}{l}0.016 \\
(0.038)\end{array}$ \\
\hline Hispanic or Spanish (ref.: White) & $\begin{array}{l}0.121 \\
(0.166)\end{array}$ \\
\hline American Indian or Alaskan Native (ref.: White) & $\begin{array}{l}-0.104 \\
(0.554)\end{array}$ \\
\hline Asian or Pacific Islander (ref.: White) & $\begin{array}{l}0.281 \\
(0.268)\end{array}$ \\
\hline Black (ref.: White) & $\begin{array}{l}0.406 * * \\
(0.184)\end{array}$ \\
\hline Other (ref.: White) & - \\
\hline Female & $\begin{array}{l}0.011 \\
(0.124)\end{array}$ \\
\hline Foreign Born & $\begin{array}{l}-0.130 \\
(0.240)\end{array}$ \\
\hline Mother in Home & $\begin{array}{l}0.346 \\
(0.271)\end{array}$ \\
\hline Father in Home & $\begin{array}{l}-0.175 \\
(0.147)\end{array}$ \\
\hline Vocabulary & $\begin{array}{l}-0.083 \\
(0.089)\end{array}$ \\
\hline Reading & $\begin{array}{l}0.070 \\
(0.089)\end{array}$ \\
\hline Math & $\begin{array}{l}0.091 \\
(0.098)\end{array}$ \\
\hline Science & $\begin{array}{l}0.129 \\
(0.098)\end{array}$ \\
\hline Writing & $\begin{array}{l}-0.060 \\
(0.099)\end{array}$ \\
\hline Civics & $\begin{array}{l}-0.007 \\
(0.081)\end{array}$ \\
\hline High School GPA & $\begin{array}{l}0.184 \\
(0.126)\end{array}$ \\
\hline Highest Math Course & $\begin{array}{l}0.127 * * \\
(0.060)\end{array}$ \\
\hline Constant & $\begin{array}{l}-2.749 * * * \\
(0.580)\end{array}$ \\
\hline Observations & 1,643 \\
\hline
\end{tabular}


Table S.53. Logistic response model of 2014 grad school entry estimated with demographic, cognitive, and noncognitive covariates and the smaller sample of respondents who completed the long-form 2014 questionnaire.

\begin{tabular}{|c|c|}
\hline & Grad School Entry \\
\hline Family Income & $\begin{array}{l}0.002 \\
(0.005)\end{array}$ \\
\hline Parental Education & $\begin{array}{l}0.073 * * \\
(0.030)\end{array}$ \\
\hline Parental SEI & $\begin{array}{l}-0.002 \\
(0.003)\end{array}$ \\
\hline Sibship Size & $\begin{array}{l}0.016 \\
(0.038)\end{array}$ \\
\hline Hispanic or Spanish (ref.: White) & $\begin{array}{l}0.122 \\
(0.167)\end{array}$ \\
\hline American Indian or Alaskan Native (ref.: White) & $\begin{array}{l}-0.109 \\
(0.552)\end{array}$ \\
\hline Asian or Pacific Islander (ref.: White) & $\begin{array}{l}0.285 \\
(0.267)\end{array}$ \\
\hline Black (ref.: White) & $\begin{array}{l}0.397 * * \\
(0.188)\end{array}$ \\
\hline Other (ref.: White) & - \\
\hline Female & $\begin{array}{l}0.009 \\
(0.127)\end{array}$ \\
\hline Foreign Born & $\begin{array}{l}-0.132 \\
(0.240)\end{array}$ \\
\hline Mother in Home & $\begin{array}{l}0.345 \\
(0.272)\end{array}$ \\
\hline Father in Home & $\begin{array}{l}-0.174 \\
(0.147)\end{array}$ \\
\hline Vocabulary & $\begin{array}{l}-0.087 \\
(0.090)\end{array}$ \\
\hline Reading & $\begin{array}{l}0.067 \\
(0.090)\end{array}$ \\
\hline Math & $\begin{array}{l}0.091 \\
(0.098)\end{array}$ \\
\hline Science & $\begin{array}{l}0.127 \\
(0.098)\end{array}$ \\
\hline Writing & $\begin{array}{l}-0.061 \\
(0.099)\end{array}$ \\
\hline Civics & $\begin{array}{l}-0.009 \\
(0.081)\end{array}$ \\
\hline High School GPA & $\begin{array}{l}0.183 \\
(0.130)\end{array}$ \\
\hline Highest Math Course & $\begin{array}{l}0.126^{* *} \\
(0.061)\end{array}$ \\
\hline Self-Esteem & $\begin{array}{l}0.009 \\
(0.059)\end{array}$ \\
\hline Locus of Control & $\begin{array}{l}0.033 \\
(0.070)\end{array}$ \\
\hline Effort & $\begin{array}{l}-0.006 \\
(0.072)\end{array}$ \\
\hline Constant & $\begin{array}{l}-2.742 * * * \\
(0.590)\end{array}$ \\
\hline Observations & 1,643 \\
\hline
\end{tabular}


Table S.54. Logistic response model of 2014 grad school attainment estimated with demographic covariates and the smaller sample of respondents who completed the long-form 2014 questionnaire.

\begin{tabular}{|c|c|}
\hline & Grad School Attainment \\
\hline Family Income & $\begin{array}{l}-0.004 \\
(0.011)\end{array}$ \\
\hline Parental Education & $\begin{array}{l}0.043 \\
(0.061)\end{array}$ \\
\hline Parental SEI & $\begin{array}{l}0.001 \\
(0.007)\end{array}$ \\
\hline Sibship Size & $\begin{array}{l}-0.026 \\
(0.077)\end{array}$ \\
\hline Hispanic or Spanish (ref.: White) & $\begin{array}{l}-0.251 \\
(0.346)\end{array}$ \\
\hline American Indian or Alaskan Native (ref.: White) & $\begin{array}{l}0.148 \\
(1.150)\end{array}$ \\
\hline Asian or Pacific Islander (ref.: White) & $\begin{array}{l}0.379 \\
(0.668)\end{array}$ \\
\hline Black (ref.: White) & $\begin{array}{l}0.140 \\
(0.409)\end{array}$ \\
\hline Other (ref.: White) & $\begin{array}{l}-2.756^{* *} \\
(1.253)\end{array}$ \\
\hline Female & $\begin{array}{l}0.256 \\
(0.251)\end{array}$ \\
\hline Foreign Born & $\begin{array}{l}-0.251 \\
(0.522)\end{array}$ \\
\hline Mother in Home & $\begin{array}{l}-0.473 \\
(0.768)\end{array}$ \\
\hline Father in Home & $\begin{array}{l}0.143 \\
(0.323)\end{array}$ \\
\hline Constant & $\begin{array}{l}1.741 \\
(1.197)\end{array}$ \\
\hline Observations & 723 \\
\hline
\end{tabular}


Table S.55. Logistic response model of 2014 grad school attainment estimated with demographic and cognitive covariates and the smaller sample of respondents who completed the long-form 2014 questionnaire.

\begin{tabular}{|c|c|}
\hline & Grad School Attainment \\
\hline Family Income & -0.001 \\
\hline & $(0.011)$ \\
\hline Parental Education & 0.041 \\
\hline & $(0.066)$ \\
\hline Parental SEI & 0.002 \\
\hline & $(0.007)$ \\
\hline Sibship Size & -0.043 \\
\hline & $(0.079)$ \\
\hline Hispanic or Spanish (ref.: White) & -0.301 \\
\hline & $(0.370)$ \\
\hline American Indian or Alaskan Native (ref.: White) & 0.323 \\
\hline & $(1.290)$ \\
\hline Asian or Pacific Islander (ref.: White) & 0.298 \\
\hline & $(0.680)$ \\
\hline Black (ref.: White) & 0.231 \\
\hline & $(0.441)$ \\
\hline & $(1.198)$ \\
\hline Female & 0.303 \\
\hline & $(0.280)$ \\
\hline Foreign Born & -0.369 \\
\hline & $(0.557)$ \\
\hline Mother in Home & -0.470 \\
\hline & $(0.762)$ \\
\hline Father in Home & 0.090 \\
\hline & $(0.345)$ \\
\hline Vocabulary & -0.211 \\
\hline & $(0.216)$ \\
\hline Reading & 0.078 \\
\hline & $(0.222)$ \\
\hline Math & 0.372 \\
\hline & $(0.240)$ \\
\hline Science & 0.072 \\
\hline & $(0.253)$ \\
\hline Civics & -0.233 \\
\hline & $(0.183)$ \\
\hline High School GPA & 0.396 \\
\hline & $(0.272)$ \\
\hline Highest Math Course & -0.172 \\
\hline & $(0.138)$ \\
\hline Constant & 1.425 \\
\hline & $(1.387)$ \\
\hline Observations & 723 \\
\hline
\end{tabular}


Table S.56. Logistic response model of 2014 grad school attainment estimated with demographic, cognitive, and noncognitive covariates and the smaller sample of respondents who completed the long-form 2014 questionnaire.

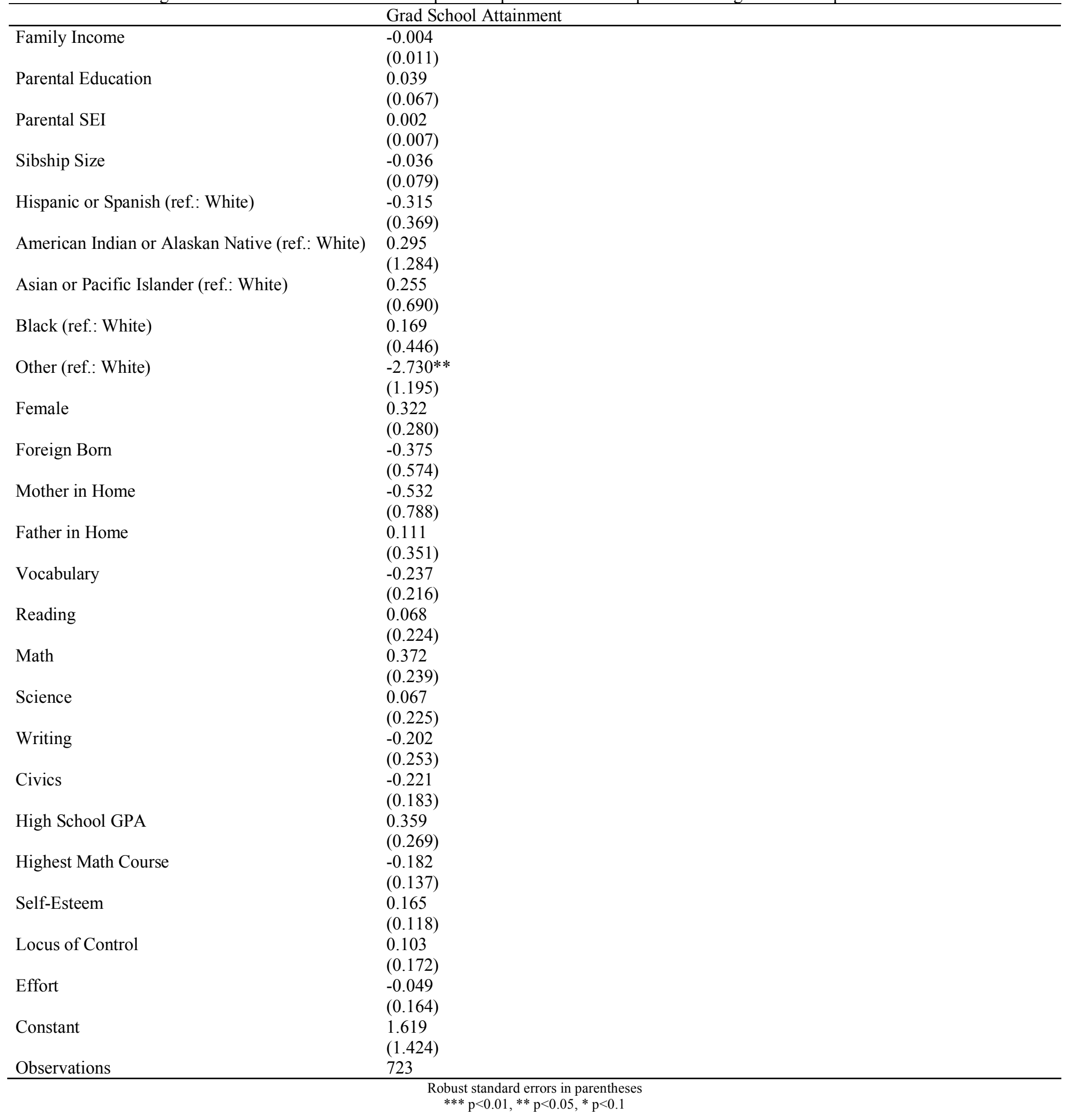

